\title{
Tritium Facilities Modernization and Consolidation Project Process WasteAssessment (Project S-7726)
}

by

R. H. Hsu

Westinghouse Savannah River Company

Savannah River Site

Aiken, South Carolina 29808

L. N. Oji

DOE Contract No. DE-AC09-89SR18035

\section{MASTER}

This paper was prepared in connection with work done under the above contract number with the U. S. Department of Energy. By acceptance of this paper, the publisher and/or recipient acknowledges the U.S. Government's right to retain a nonexclusive, royalty-free license in and to any copyright covering this paper, along with the right to reproduce and to authorize others to reproduce all or part of the copyrighted paper. 


\section{WSRC-TR-97-00368 \\ Project S-7726}

Tritium Facilities Modernization \& Consolidation Project

$$
\text { Process Waste Assessment (U) }
$$

(Waste Assessment and Treatment and Disposal Option Assessment)

$$
\text { Rev. } 0
$$

November 14, 1997

Robert H. Hsu

Lawrence N. Oji

Savannah River Technology Center

Westinghouse Savannah River Company

Aiken, SC 29808 


\section{DISCLAIMER}

This report was prepared as an account of work sponsored by an agency of the United States Government. Neither the United States Government nor any agency thereof, nor any of their employees, makes any warranty, express or implied, or assumes any legal liability or responsibility for the accuracy, completeness, or usefulness of any information, apparatus, product, or process disclosed, or represents that its use would not infringe privately owned rights. Reference herein to any specific commercial product, process, or service by trade name, trademark, manufacturer, or otherwise does not necessarily constitute or imply its endorsement, recommendation, or favoring by the United States Government or any agency thereof. The views and opinions of authors expressed herein do not necessarily state or reflect those of the United States Government or any agency thereof.

This report has been reproduced directly from the best available copy.

Available to DOE and DOE contractors from the Office of Scientific and Technical Information, P.O. Box 62, Oak Ridge, TN 37831; prices available from (615) 576-8401.

Available to the public from the National Technical Information Service, U.S. Department of Commerce; 5285 Port Royal Road, Springfield, VA 22161. 


\section{DISCLAIMER}

Portions of this document may be illegible electronic image products. Images are produced from the best available original document. 
Tritium Facilities Modernization \& Consolidation Project Process Waste Assessment
WSRC-TR-97-00368, Rev. 0 November 14, 1997

WSRC-TR-97-00368

Project S-7726

Tritium Facilities Modernization \& Consolidation Project

Process Waste Assessment (U)

(Waste Assessment and Treatment and Disposal Option Assessment)

Rev. 0

November 14, 1997

Prepared by:

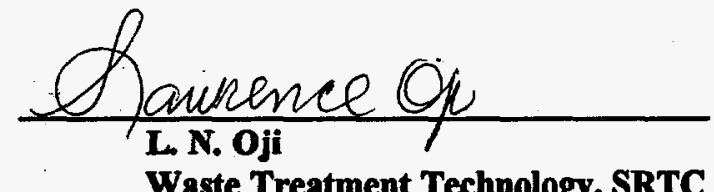

Date: $12 / 4 / 97$

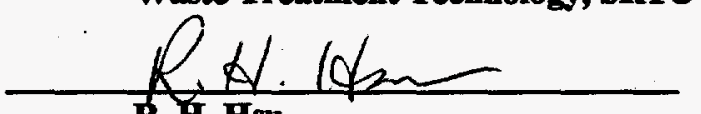

R. H. Hsu

Chemical \& Hydrogen Technology, SRTC

Approved by:

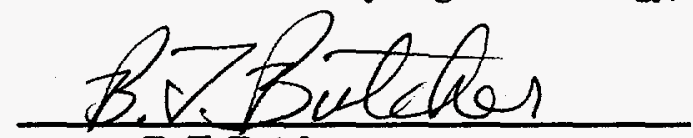

B. T. Butcher

Level 4 Manager, WTT, SRTC

Approved by:

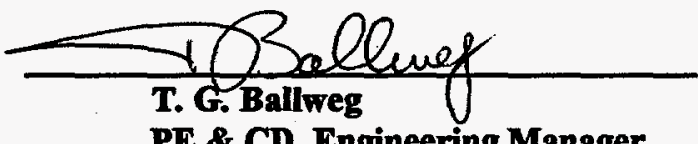

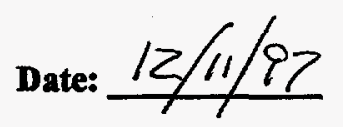

Date: $12-12-97$

Classification Reviewed by:

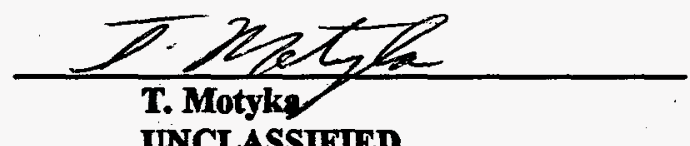

Date: $12 / 11 / 02$ 
Tritium Facilities Modemization \& Consolidation Project Process Waste Assessment
WSRC-TR-97-00368, Rev. 0

November 14, 1997

\section{List of Acronyms and Abbreviations}

\begin{tabular}{|c|c|}
\hline $\mathrm{Ag}$ & Silver \\
\hline $\begin{array}{l}\text { Al } \\
\text { AlNiCo }\end{array}$ & $\begin{array}{l}\text { Aluminum } \\
\text { Aluminum-Nickel-Cobalt }\end{array}$ \\
\hline $\begin{array}{l}\text { AlNiCo } \\
\text { ALARA }\end{array}$ & $\begin{array}{l}\text { Aluminum-Nickel-Cobalt } \\
\text { As Low As Reasonably Achievable }\end{array}$ \\
\hline APT & Accelerator for the Production of Tritium \\
\hline $\mathrm{Ar}$ & Argon \\
\hline ASTM & American Society of Testing and Materials \\
\hline $\mathbf{B a}$ & Barium \\
\hline BDAT & Best Demonstrated Available Technology \\
\hline BNL & Brookhaven National Laboratory \\
\hline C & Carbon \\
\hline${ }^{\circ} \mathrm{C}$ & Celsius degree (unit of temperature) \\
\hline CAI & Controlled Air Incinerator \\
\hline CAM & Continuous Air Monitor \\
\hline cc & Cubic centimeter \\
\hline $\mathrm{Cd}$ & Cadmium \\
\hline CERCLA & $\begin{array}{l}\text { Comprehensive Environmental Responsibility, Compensation, } \\
\text { and Liability Act of } 1981\end{array}$ \\
\hline CFC & Chloroflurocarbon \\
\hline cfm & Cubic Feet per Minute \\
\hline CFR & Code of Federal Regulations \\
\hline $\mathbf{C i}$ & Curies \\
\hline CIF & Consolidated Incineration Facility (at SRS) \\
\hline CLWR & Commercial Light Water Reactor \\
\hline CLWR-TEF & Commercial Light Water Reactor-Tritium Extraction Facility \\
\hline COBRA & COmputerized (Radioactive Waste) Burial Record Analysis (at \\
\hline SRS) & \\
\hline $\mathbf{C r}$ & Chromium \\
\hline CRM & Count Rate Meter \\
\hline $\mathrm{Cu}$ & Copper \\
\hline D & Deuterium Isotope of Hydrogen \\
\hline D\&D & Decontamination \& Decommissioning \\
\hline DCF & Design Change Form \\
\hline DCS & Distributed Control System \\
\hline $\mathrm{D}_{\mathbf{2}} \mathrm{O}$ & Deuterium Oxide (Heavy Water) \\
\hline DOE & Department of Energy \\
\hline DOP & Dioctyl phthalate (used to check HEPA filter efficiency) \\
\hline $\mathrm{dpm}$ & Disintegrations per Minute \\
\hline DSSI & Diversified Scientific Services, Inc. (Oak Ridge, TN) \\
\hline DWPF & Defense Waste Processing Facility (Vitrification Facility at SRS) \\
\hline
\end{tabular}




\begin{tabular}{|c|c|}
\hline EA & Environmental Assessment \\
\hline EAV & E-Area Vaults (at SRS) \\
\hline EIS & Environmental Impact Statement \\
\hline EPA & Environmental Protection Agency \\
\hline ES\&H & Environmental, Safety \& Health \\
\hline ETF & $\begin{array}{l}\text { Effluent Treatment Facility (Liquid Waste Treatment Facility at } \\
\text { SRS) }\end{array}$ \\
\hline${ }^{\circ} \mathbf{F}$ & Fahrenheit degree (unit of temperature) \\
\hline FDD & Facility Design Description \\
\hline FFCA & Federal Facilities Compliance Act of 1992 \\
\hline ft & foot or feet \\
\hline $\mathbf{F Y}$ & Fiscal Year \\
\hline gpm & Gallons per Minute \\
\hline $\mathbf{H}$ & Hydrogen (Protium Isotope) \\
\hline He-3 & Helium-3 \\
\hline HEPA & High Efficiency Particulate Air (Filter) \\
\hline $\mathbf{H g}$ & Mercury \\
\hline HLW & High-Level Waste \\
\hline HSV & Hydride storage vessel \\
\hline HTO & Hydrogen Tritium Oxygen (Tritiated water) \\
\hline HTV & Hydride transport vessel \\
\hline HVAC & Heating, Ventilation and Air Conditioning \\
\hline HW/MW DF & Hazardous Waste/Mixed Waste Disposal Facility (at SRS) \\
\hline I. D. & Inside diameter \\
\hline ILNTV & Intermediate Level Non-Tritium Vaults (part of SRS ILV) \\
\hline ILTV & Intermediate Level Tritium Vaults (part of SRS ILV) \\
\hline IILV & Intermediate Level Vaults (part of SRS E-Area Vaults) \\
\hline INEL & Idaho National Engineering Laboratory \\
\hline ITP & $\begin{array}{l}\text { In-Tank Precipitation (Liquid waste pre-treatment facility for } \\
\text { DWPF) }\end{array}$ \\
\hline JCW & Job Control Waste \\
\hline${ }^{\circ} \mathrm{K}$ & Degree Kelvin \\
\hline KD-0 & Key Decision Zero \\
\hline kg & kilogram or 1000 gram (unit of mass) \\
\hline 1 & liter \\
\hline LANA & $\underline{\text { LAnthanum Nickel Aluminum (Metal Hydride Bed Fill Material) }}$ \\
\hline LANL & Los Alamos National Laboratory \\
\hline lb & pound \\
\hline LDR & Land Disposal Restriction \\
\hline LiAl & Lithium Aluminum \\
\hline LLW & Low-Level Waste \\
\hline $\begin{array}{l}\mathrm{m}^{3} \\
\mathrm{MCC} \\
\mathrm{Mg}\end{array}$ & $\begin{array}{l}\text { Cubic Meters } \\
\text { motor control center } \\
\text { Magnesium }\end{array}$ \\
\hline
\end{tabular}




$\begin{array}{ll}\text { min } & \text { minute } \\ \text { mCi/cc } & \text { Micro (10-6) Curies per cubic centimeter } \\ \text { MLLW } & \text { Mixed Low-Level Waste } \\ \text { mrem } & \text { millirem (absorbed radiation dose) } \\ \text { MTF } & \text { Materials Test Facility } \\ \text { Na } & \text { Sodium } \\ \text { NEPA } & \text { National Environmental Policy Act of 1969 } \\ \text { NESHAP } & \text { National Emission Standards for Hazardous Air Pollutants } \\ \text { Ni } & \text { Nickel } \\ \text { NPDES } & \text { National Pollutant Discharge Elimination System } \\ \text { NRC } & \text { Nuclear Regulatory Commission } \\ \text { NTS } & \text { Nevada Test Site } \\ \text { O.D. } & \text { Outside diameter } \\ \text { Pb } & \text { Lead } \\ \text { Pd } & \text { Palladium } \\ \text { PICs } & \text { Products of Incomplete Combustion } \\ \text { psig } & \text { Pounds per square inch gauge } \\ \text { Pt } & \text { Platinum } \\ \text { PFR } & \text { Plug Flow Reverser } \\ \text { PCi/ml } & \text { Pico (10-12) Curies per milliliter } \\ \text { PMR } & \text { Palladium Membrane Reactor } \\ \text { PNNL } & \text { Pacific Northwest National Laboratory } \\ \text { PPOA } & \text { Pollution Prevention Opportunity Assessment } \\ \text { PPE } & \text { Personal Protective Equipment } \\ \text { PV } & \text { Product vessel } \\ \text { PVC } & \text { Poly(vinyl chloride) } \\ \text { P-V-T-C } & \text { Pressure-Volume-Temperature-Composition (Tritium } \\ & \text { accountability method) } \\ \text { PWA } & \text { Process Waste Assessment } \\ \text { QA } & \text { Quality Assurance } \\ \text { R\&D } & \text { Research and Development } \\ \text { RBOF } & \text { Receiving Basin for Off-site Fuel ( SRS H-Area Facility) } \\ \text { RCRA } & \text { Resources Conservation and Recovery Act of 1976 } \\ \text { RMA } & \text { Radiological Materials Area } \\ \text { RMERC } & \text { Retorting or Roasting of Mercury } \\ \text { RTF } & \text { Replacement Tritium Facility, SRS Building 233-H } \\ \text { S \& S } & \text { Safeguards and Security } \\ \text { SCDHEC } & \text { South Carolina Department of Health and Environmental Control } \\ \text { SDD } & \text { System Design Description } \\ \text { SEG } & \text { Scientific Ecology Group (Oak Ridge, TN) } \\ \text { SNL-NM } & \text { Sandia National Laboratories - New Mexico } \\ \text { SpG } & \text { Specific Gravity } \\ \text { SRS } & \text { SRTechnology Center } \\ \text { SRTC } & \\ & \end{array}$


Tritium Facilities Modernization \& Consolidation Project Process Waste Assessment
WSRC-TR-97-00368, Rev. 0

November 14, 1997
$T$

TBD

TCAP

TCLP

TEF

TFM \& C

TOC

TPBAR

TRU

TRU Waste

TSCA

TSD

TSTA

U

UPS

VOC

vol

WAC

WERF

WIPP

WITS

WM

WRAP

WSRC

Z-Bed
Tritium Isotope of Hydrogen

To Be Determined

Thermal Cycling Absorption Process (Method for hydrogen isotopic separation)

Toxicity Characteristic Leaching Procedure (e.g., EPA Method 1311)

Tritium Extraction Facility

Tritium Facilities Modernization and Consolidation (Project)

Total Organic Carbon

Tritium Producing Burnable Absorber Rod

Transuranic (e.g. Pu)

Transuranic Waste

Toxic Substances Control Act (40CFR761)

Treatment, Storage, and Disposal (waste management facility)

Tritium Systems Test Assembly (at LANL)

Uranium

Uninterruptible Power Supply

Volatile Organic Compounds

Volume

Waste Acceptance Criteria

Waste Experimental Reduction Facility (at INEL)

Waste Isolation Pilot Plant (TRU Waste Disposal Facility in New Mexico)

Waste Information Tracking System (at SRS)

Waste Management

Waste Receiving and Processing Facilities (at Hanford)

Westinghouse Savannah River Company

Zeolite Bed 


\section{Table of Contents}

1. Introduction 1

2. Purpose 1

3. Background 2

4. Methodology 3

4.1 Process Definition 3

4.2 Process Characterization $\quad 3$

4.3 Waste Minimization Assessment 4

4.4 Waste Treatment and Disposal 5

5. Summary 5

5.1 Process Waste Streams 5

$\begin{array}{lll}5.2 & \text { Tritium as Contaminant Source } & 7\end{array}$

5.3 Waste Treatment and Disposal 7

5.3.1 Waste Treatment 7

5.3.2 Waste Disposal 9

5.4 PWA Critical Assumptions 9

5.5 Challenging Waste Streams and Waste Management Issues 10

5.5.1 Tritiated Liquid Waste 10

5.5.2 Tritium Permeation and Quantification 11

5.5.3 TFM \& C Process Technology Uncertainties 11

5.6 Waste Minimization Technologies and Process Development 11

5.6.1 Palladium Membrane Reactor 11

5.6.2 Solid Oxide Electrolysis $\quad 12$

$\begin{array}{lll}\text { 5.6.3 Tritium Getters } & 12\end{array}$ 
5.6.4 Advanced TCAP 13

5.6.5 Hydride Bed Heating/Cooling Alternatives 13

6. Conclusions 13

7. References 14

Appendix A, TFM \& C Processes and Operations A-1

A1. Tritium/Product Processing A-4

A2. Tritium Process Confinement and Clean-up Systems A-6

A3. Tritium Process Stripping A-8

A4. Metallurgical Lab/Life Storage Program Operations A-9

A5. Tritium Analysis and Accountability A-9

A6. Balance of Plant Facilities A-11

Appendix B, TFM \& C Hazardous, Low-Level and Mixed Waste Streams B-1

B1. Job Control Waste (H-3) B-5

$\begin{array}{ll}\text { B1a. Non-hazardous Solvent } & \text { B-8 }\end{array}$

B2. Job Control Waste (Mixed Low-Level Waste) B-9

$\begin{array}{ll}\text { B2a. Mixed Waste Solvent Rags } & \text { B-10 }\end{array}$

B3. Non-hazardous Process Equipment (H-3) B-11

$\begin{array}{ll}\text { B4. Magnesium/Uranium Beds } & \text { B-13 }\end{array}$

B5. Hydride/Getter/Catalyst/Zeolite Beds B-15

B6. Mixed Waste Process Equipment - B-18

B6a. Teledyne Oxygen Sensor Micro-Fuel Cells B-20

B7. Mixed and Hazardous Waste Oil/Solvent B-21

B8. Analytical Laboratory/Rad Con Chemicals B-23

B9. Non-hazardous Tritiated Oil $\quad$ B-26

$\begin{array}{ll}\text { B9a. Glovebox Bubbler Fluid } & \text { B-28 }\end{array}$

$\begin{array}{ll}\text { B10. Classified Low Level Waste } & \text { B-30 }\end{array}$ 
Tritium Facilities Modernization \& Consolidation Project Process Waste Assessment
WSRC-TR-97-00368, Rev. 0

November 14, 1997

B11. Mixed Waste Mercury

B12. Palladium/Electrolysis Membrane

B-32

Absorbent Wipes (See B1,B2,B2a)

Analytical Cocktails (See B8)

Analytical Laboratory Chemicals (See B8)

Batteries, Ni-Cd and Lead Acid (See B6)

Beds, Catalyst (See B5)

Beds, Getter (See B5)

Beds, Hydride (See B5)

Beds, Magnesium (See B4)

Beds, Uranium (See B4)

Beds, Zeolite (See B5)

Catalytic Purifier (See B5)

Classified Waste (See B10)

Cutting Fluid (See B7, B9)

Diffusers, Pd-Ag (See B6)

Electrolysis Membrane (See B12)

Filters (See B1, B3)

Gaskets (See B1,B2)

Gauges (See B3)

Gloves, Butyl Rubber (See B1,B2)

Gloves, Latex (See B1,B2)

Glovebox Parts (See B3)

Glovebox Bubbler Fluid (See B9a)

Hydride Storage Vessel (See B5)

Hydride Transport Vessel (See B5)

Instruments (See B3)

Instrument- Computer boards ( See B3, B6)

Light bulbs, Fluorescent (See B3)

Oil (See B9)

Paint Shop Waste (See B1,B2)

Palladium Membrane Reactor (See B12)

Paper, Kraft (See B1,B2)

Photographic Waste (See B2)

Plastic Bags (See B1,B2)

Plastic Sheeting (See B1,B2)

Plastic Shoe Covers (See B1,B2)

Plastic Suits/Air Hoses (See B1)

Product Vessels (See B3)

Pumps, Nometex (See B3)

Pumps, Vacuum (See B3)

Rad Con Chemicals (See B8) 
Reservoir Fragments (See B10)

Solvent Rags, Wipes (See B1,B1a,B2,B2a,B7)

Solvent, Spent (See B1a,B7)

Stainless Steel Tanks/Piping (See B3)

Valves (See B3)

Welding Waste (See B1)

Appendix C, Treatment and Disposal of TFM \& C Waste

C-1

C1. TFM \& C Waste Disposition

C-2

C1.1 Low-Level Waste

C-2

C1.2 Mixed Low-Level Waste

C1.3 Hazardous Waste

C2. Existing and Planned SRS Waste Treatment Facilities

C2.1 E-Area Vaults

C2.2 Consolidated Incineration Facility

C2.3 Hazardous/Mixed Waste Storage Pads/Buildings

C2.4 Sanitary Landfill

C2.5 Effluent Treatment Facility

C2.6 Sanitary Sewage Treatment Facility

C-7

C2.7 Hazardous Waste/Mixed Waste Disposal Facility

C-7

C2.8 Prohibited Wastes

C-8

C3. Other DOE and Commercial Waste Treatment Facilities

C-8

C3.1 Hanford

C-11

C3.2 Nevada Test Site

C-11

C3.3 Scientific Ecology Group (SEG)

C-11

C3.4 Diversified Scientific Services, Inc. (DSSI)

C-12

C3.5 Envirocare

C-12

C3.6 GTS Duratek

C4. Treatment Technologies 
Tritium Facilities Modernization \& Consolidation Project Process Waste Assessment
WSRC-TR-97-00368, Rev. 0 November 14, 1997
C4.1 Compaction

C-13

C4.2 Thermal Desorption

C-14

C4.3 Incineration

C-14

C4.4 Stabilization

C-15

C4.5 Vitrification

C-15

C4.6 Encapsulation

C4.7 Metals Recovery

Appendix D, Waste Stream Inventory by Waste Type

Appendix E, Waste Stream Inventory by Waste Treatment Category

Appendix F, EPA Hazardous Waste Codes with Sub-categories
C-16

C-16

D-1

E-1

F-1 
Tritium Facilities Modernization \& Consolidation Project Process Waste Assessment

\section{List of Tables}

Table 1 Estimated Annual Waste Generation Rates for TFM\&C Project

6

Table 2 Treatment/Disposal Options for TFM\&C Waste 8

Table B1 SRS FY97-98 Tritium Waste Forecast

B-4

Table B2 Tritium Analytical Laboratory/Rad Con Tier II

Hazardous Chemical Inventory

B-24

Table C1 Existing and Planned DOE Waste Treatment Facilities

Relevant for TFM \& C Waste

C-9

Table F1 EPA Hazardous Waste Indexes

F-1

\section{List of Figures}

Figure A-1 TFM\&C Process Schematic

A-3

Figure C-1 TFM\&C Waste Management Facilities

C-3 
Tritium Facilities Modernization \& Consolidation Project

Process Waste Assessment
WSRC-TR-97-00368, Rev. 0

November 14, 1997

[This Page Intentionally Left Blank] 


\section{Introduction}

Under the Tritium Facility Modernization \& Consolidation (TFM\&C) Project (S-7726) at the Savannah River Site (SRS), all tritium processing operations in Building 232-H, with the exception of extraction and obsolete/abandoned systems, will be reestablished in Building 233-H. These operations include hydrogen isotopic separation, loading and unloading of tritium shipping and storage containers, tritium recovery from zeolite beds, and stripping of nitrogen flush gas to remove tritium prior to stack discharge. The scope of the TFM\&C Project also provides for a new replacement R\&D tritium test manifold in 233-H, upgrading of the 233-H Purge Stripper and 233H/234-H building HVAC, a new 234-H motor control center (MCC) equipment building and relocating 232-H Materials Test Facility metallurgical laboratories (met labs), flow tester and life storage program environmental chambers to $234-\mathrm{H}$.

The scope of this Process Waste Assessment (PWA) will include the new TFM\&C replacement tritium production process operations and tritium $R \& D$ test manifold to be installed in 233-H and the met lab operations to be relocated to 234-H. As with any process, TFM\&C waste stream characteristics will depend on process feedstock and contaminant sources.

\section{Purpose}

DOE has made a commitment for the Tritium Facilities Modernization \& Consolidation Project to comply with all applicable environmental regulatory requirements. In this respect, it is important to consider and design all tritium extraction processing alternatives so that they can comply with these requirements. The management of waste is an integral part of this activity and it is therefore necessary to estimate the quantities and specific wastes that will be generated by the TFM\&C facilities. A thorough assessment of waste streams includes waste characterization, quantification, and the identification of treatment and disposal options. This PWA provides waste stream characterization and quantification information required to meet the waste generation and waste minimization requirements defined in 40 CFR 268 (Land Disposal Restrictions), 40 CFR 260-5, DOE Orders 5820.2A, 6430.1A, and the 5400.xx and 5480.xx series. It is based on the format of a PWA developed in 1994 by Sandia National Laboratories-New Mexico (SNL-NM) for the APT (Ref. 1) and is intended to provide partial data for an Environmental Assessment (EA) or Environmental Impact Statement (EIS) such as in Ref. 2-3. (Note: The periodic PWAs conducted by Operating Facilities at SRS are being renamed Pollution Prevention Opportunity Assessments (Ref. 4). However, for consistency with similar analyses for other tritium projects, the Process. Waste Assessment title is retained for this study.)

The management and ultimate disposal of waste is a costly and complicated activity involving established internal procedures, permitting, and other regulatory issues. The costs and lead times associated with these issues should be estimated and considered along with other design and engineering costs. This PWA provides data for cost-benefit analysis of the potential environmental impact of the TFM\&C facilities, is an integral part of waste minimization, and is required by DOE for any activity that will generate radioactive, hazardous, and mixed wastes. It will also better position the TFM\&C Project facilities to meet future requirements, since it is anticipated that regulatory and other requirements will continue to become more restrictive and demanding. 
A PWA is also essential for the evaluation of the design or technology options proposed for the TFM\&C Project. An important consideration in technologies such as tritium recovery from zeolite beds (Z-Bed Recovery) and other design feature selection is the assessment of waste streams and quantities produced. Waste stream analysis will demonstrate whether advantages in terms of: waste volumes and characteristics may result from the use of a certain technology and/or design features.

\section{Background}

The DOE is responsible for research, development, and testing of nuclear weapons for the Department of Defense. These responsibilities include production of certain critical materials required for the weapons. One such material is tritium, a gaseous isotope of hydrogen used to enhance the explosive power of nuclear warheads. Tritium is radioactive, and about 5.5 percent is lost each year through natural decay (12.3 years half-life). Because of this loss, existing weapons must be re-supplied periodically with tritium in order to maintain their effectiveness.

In the 1950's, DOE began producing tritium in nuclear reactors located at the Savannah River Site near Aiken, South Carolina. The existing tritium extraction and processing facilities in 232-H and 234-H date from that time. The design philosophy at the time focused primarily on worker safety and tritium process equipment were located either in high-velocity air hoods or in the rooms. Mitigation of tritium releases in the event of an accident was limited. In the early 1990's, the Replacement Tritium Facility (RTF) in 233-H replaced all tritium loading and unloading functions previously carried out in 234-H. In the RTF, all tritium process equipment were secondarily confined in gloveboxes or jacketed piping; the first large-scale tritium handling facility in the DOE Complex to do so. Recently DOE directed that tritium processing operations in 232- $\mathrm{H}$, except for extraction and obsolete operations, will be modernized and consolidated to available space in 233-H under the TFM\&C Project. These operations include hydrogen isotopic separation, loading and unloading of tritium shipping and storage containers, tritium recovery from zeolite beds, and stripping of nitrogen flush gas to remove tritium prior to stack discharge. A replacement tritium R\&D test manifold will also be installed in 233-H. The SRTC Materials Test Facility metallurgical labs, flow tester and Life Storage Program environmental chambers in 232-H are also to be relocated to 234-H under this project. Supporting facilities to be upgraded under this project include increased Purge Stripper capacity, 233-H/234-H building HVAC and a new 234-H MCC building. The primary goals of the TFM\&C Project are to effect cost savings by eventually shutting down building $232-\mathrm{H}$ and to reduce the potential for tritium release to the environment.

The TFM\&C Project will interface with other ongoing tritium projects. In 1988, concerns about operational safety led DOE to shut down or place in standby all SRS production reactors, effectively stopping the production of tritium. Two primary alternatives are now being considered for meeting future requirements for tritium production: 1) Accelerator for the Production of Tritium (APT), and 2) Commercial Light Water Reactor (CLWR) production of tritium using lithium aluminate Tritium Producing Burnable Absorber Rods (TPBARs) and shipment of the irradiated TPBARs to a Tritium Extraction Facility at SRS to extract and purify the tritium. The Tritium Extraction Facility will replace the current extraction capability in 232-H. In support of the CLWR-Tritium Extraction Facility alternative, the TFM\&C Project will provide facilities that: will consolidate extraction gas purification and hydrogen isotope separation. DOE started funding design for the TFM\&C Project in 1996. The TFM\&C facilities are not expected to introduce or 
process materials that could lead to criticality issues and there will be no generation of high-level waste (HLW).

\section{Methodology}

This PWA is concerned with characterization of all process waste streams generated during normal operation of the TFM\&C Project facilities to purify tritium from the TEF. Because the TFM\&C facility design is only in the conceptual design phase, waste streams generated at the end of the life of the facility during the decontamination and decommissioning (D\&D) phase and wastes from accidents are not examined in depth. Sanitary sewage and wastewater are estimated based on TFM\&C facility staffing levels. Qualitative and quantitative assessments were performed for all process-specific waste streams, and non-process activities such as maintenance and repair. The envelope examined includes all tritium processing steps from receipt at TFM\&C of CLWR-TEF furnace extraction gas exiting the flow-through bed, passing through a diffuser and a hydrogen isotope separation system to produce tritium of the desired purity for transfer to reservoir loading operations. Supporting tritium process operations examined include loading and unloading of tritium shipping and storage containers, stripping of glovebox gases to remove tritium, tritium recovery from zeolite beds, stripping of nitrogen flush gas and diffuser effluent gas to remove tritium; and operations involving Materials Test Facility metallurgical labs, tritium test manifold, flow tester and Life Storage Program environmental chambers.

There are four parts to this PWA: process definition, process characterization, waste minimization assessment, and waste treatment and disposal. "Process" is used broadly here to include any operation that generates a waste or pollutant, or uses a hazardous or radioactive material.

\subsection{Process Definition}

Process definition briefly describes the overall operations and the specific processes or operations that consume or generate sanitary, hazardous and/or radioactive materials or wastes. Each of these processes is discussed in Appendix A, TFM\&C Processes and Operations. A simplified process schematic for the TFM\&C is also given in Appendix A. For this discussion, TFM\&C processes are organized into six areas:

- Tritium/Product Processing

- Tritium Process Confinement and Clean-Up Systems

- Tritium Process Stripping

- Metallurgical Laboratory/Life Storage Operations

- Tritium Analysis and Accountability

- Balance of Plant Facilities

\subsection{Process Characterization}

Process characterization collects information about the quantity and nature of the hazardous and/or radioactive materials used in tritium extraction and purification processes and the wastes and other pollutants generated. This information was obtained from a variety of sources such as experience of existing SRS and LANL tritium facilities, projected levels of production 
activities, and engineering estimates. Most TFM\&C processes are still in the conceptual design stage and the information needed for a complete characterization is not yet available. Several wastes identified are not the result of a process, but rather are from site-wide maintenance of process equipment or from failure of process equipment and components through usage or exposure to harsh environments. Wastes from all processes are grouped into waste streams with similar characteristics and modes of generation.

Appendix B provides the following information for each of 13 identified TFM\&C waste streams that may contain hazardous and/or radioactive constituents:

Type: Identifies a solid waste stream as either hazardous waste, low-level radioactive waste, intermediate-level waste, mixed low-level or transuranic waste. Intermediate-level waste is a subset of low-level waste; it is used to designate low-level waste that emit greater than 200 $\mathrm{mRad} / \mathrm{hr}$ closed window reading at $5 \mathrm{~cm}$ from the container surface. Radioactive liquid waste streams are also identified as such. No intermediate-level or transuranic waste is expected to be generated by the TFM\&C facilities.

Description: Waste stream physical matrix, chemical composition, RCRA components and hazardous waste codes present, and anticipated radioactive isotopes and activity levels.

Generation: A description of the processes or activities that generate the waste stream.

Handling and Packaging A description of current or recommended handling and packaging techniques for the waste stream.

Annual Quantities: Estimated annual generation rates in both mass and volume. Quantities are based on experience of DOE facilities with similar operations or using similar components, assumed levels of production activities and engineering judgment.

Treatment Options: Lists possible treatment technologies for LLRW or MLLW. Descriptions of the listed treatment technologies are given in Appendix C. It is assumed that hazardous waste which cannot be incinerated in the SRS Consolidated Incineration Facility (CIF) will be packaged for treatment and/or disposal at a DOE-approved DOE or commercial waste management facility. One notable exception is corrosive-only hazardous waste that must be treated by the waste generator before disposal.

Comments: Provides additional information pertinent to understanding the nature of the waste stream or its treatment, which do not fit in with other categories.

\subsection{Waste Minimization Assessment}

The waste minimization assessment identifies and evaluates various alternatives for reducing or eliminating the waste stream, or for eliminating either the hazardous or radioactive component in the mixed low-level waste. A detailed understanding of how hazardous materials are used and wastes are generated in the process is critical to the success of this effort. Waste minimization is addressed under a separate sub-heading for each waste stream listed in Appendix B. 


\subsection{Waste Treatment and Disposal}

TFM\&C process waste streams will have to be managed for treatment and disposal according to waste type; i.e., sanitary, hazardous, low-level, or mixed low-level waste, in accordance with the requirements of DOE Order 5820.2A and other applicable DOE Orders. At SRS, operating divisions must provide a facility Waste Certification Plan to the Solid Waste Management Division for approval. The Waste Certification Plan and individual waste stream characterization plans must be approved, and the Waste Management Facility Waste Acceptance Criteria must be met before waste can be shipped to the Solid Waste Management Division for treatment, storage and/or disposal (Ref. 5).

Waste treatment options that currently exist or are expected to be available by the time the TFM\&C facilities are built are listed for each waste stream in Appendix B. If more than one treatment method is feasible for a particular waste stream, no attempt is made to prioritize or recommend specific treatments; such recommendations would necessarily be based on cost-benefit analyses, trade studies and risk assessments that would be performed at a later stage of design development. If a treatment generates secondary waste that also requires treatment, it is discussed in the context of the primary TFM\&C waste stream and the secondary waste is not listed as a separate waste stream.

SRS, DOE, and commercial low-level and mixed waste treatment/disposal facilities are presented in Appendix C, Treatment and Disposal of TFM \&C Waste. Brief descriptions of treatment technologies that are currently available or are expected to be available by the time TFM\&C facilities are built are also presented in Appendix $\mathbf{C}$.

\section{Summary}

This PWA was developed based on conceptual design information. A final conceptual design of the TFM\&C facilities and system design descriptions will not be available until early 1998. The anticipated waste streams identified and projected quantities reported here reflect design data in the TFM\&C Project S-7726 Baseline of May 22, 1997 (Ref. 6), conceptualized modes of operation, assumed levels of production activities and engineering judgment. Development of this PWA will be an iterative process. The waste stream information should be refined as the design progresses, preferred technologies are selected, and operational uncertainties and assumptions are refined.

\subsection{Process Waste Streams}

Radioactive waste in the TFM\&C facilities is generated from processing of tritium in 233$\mathrm{H}$ and metallurgical samples in 234-H. Tritium processing and metallurgical examinations generate waste streams contaminated with tritium. Wastes are generated as part of the production process, decontamination process, analytical activities, housekeeping and operation of supporting facilities. They are also generated incidentally through failed equipment, routine maintenance and due to off-normal events. 
Twelve (12) TFM\&C process waste streams have been identified and are described in Appendix B. Estimates of the annual uncompacted, containerized waste generation rates by waste type, mass and volume are summarized from Appendix B and presented in Table 1. A similar table has been developed for the Environmental Assessment (EA) Input Submittal report. A summary of waste stream data by waste type (low-level, hazardous or mixed) is provided in Appendix D and a summary by waste treatment category in Appendix E.

Table 1. Estimated Annual Waste Generation Rates for the TFM\&C Facilities

\begin{tabular}{|l|c|c|c|}
\hline \multicolumn{1}{|c|}{ Waste Type } & $\begin{array}{c}\text { Mass } \\
\mathrm{kg} / \mathrm{yr}\end{array}$ & $\begin{array}{c}\text { Volume } \\
\mathrm{m}^{3} / \mathrm{yr}\end{array}$ & $\begin{array}{c}\text { Avg Waste } \\
\text { Density } \\
\mathrm{kg} / \mathrm{m}^{3}\end{array}$ \\
\hline Transuranic Waste & 0 & 0 & - \\
\hline High-Level Waste & 0 & 0 & 246 \\
\hline $\begin{array}{l}\text { Low-Level Radioactive } \\
\text { Waste }\end{array}$ & 9,600 & 39 & 977 \\
\hline Hazardous Waste & 293 & 0.3 & 152 \\
\hline Mixed Low-level Waste & 760 & 5.0 & 1,000 \\
\hline Liquid Sanitary Sewage & $4,900,000$ & 4,900 & 250 \\
\hline Solid Sanitary Sewage & 58,000 & 230 & \\
\hline
\end{tabular}

The numbers given here should not be considered the total wastes for TFM\&C facilities; they are the totals for waste streams that can be quantified at this time. Appendix B has a number of waste streams for which the quantities cannot be determined at the current design stage, and the numbers presented do not include contingency for these streams.

Job control waste, primarily personal protection equipment (PPE), from the TFM\&C facility operations is estimated at $40 \mathrm{~m}^{3} / \mathrm{yr}$. The total estimate for all job control waste streams is $\sim 5,800 \mathrm{~kg} / \mathrm{yr}$. All JCW volumes are for uncompacted, containerized waste.

Job control waste streams for the TFM\&C facilities are reduced from current SRS Tritium Facilities baseline forecasts for similar activities based on the expectation that waste minimization initiatives will reduce waste generated by TFM \&C facilities start-up by $50 \%$ for comparable activities, on several years of 233-H operating experience and on over ten years' of operating experience at the LANL Tritium Systems Test Assembly (TSTA). The TSTA is a tritium processing and cryogenic distillation purification facility which has processed approximately 100 $\mathrm{kg}$ of tritium during this period (averaging $10 \mathrm{~kg} / \mathrm{yr}$ ) using triple containment designs. During this ten-year period of continuous facility operation (all of the following statements are from Ref. 7 ),

- TSTA has never had a spill.

- Glovebox gloves have not needed to be changed.

- Approximately ten pairs of latex gloves have been used.

- Approximately $100 \mathrm{~kg}$ of plastic sheeting has been used.

- Approximately $45 \mathrm{~kg} / \mathrm{yr}$ of plastic bags are used.

- Plastic shoe covers are used an average of less than once a year.

- Plastic suits and air hoses have never been used. 
The TFM\&C facilities will be designed to minimize the need for "plastic suit work" and the resulting wastes. Secondary or double containment systems such as that used at TSTA (Ref. 8) or the 233-H RTF at SRS (Ref. 9-11) will allow for many maintenance activities to be performed in gloveboxes and are expected to minimize waste generation.

\subsection{Tritium as Contaminant Source}

Tritium is a radioactive isotope of hydrogen with a half life of 12.3 years. It has a specific activity of about $9,600 \mathrm{Ci} / \mathrm{gm}$. It is a pure beta emitter with a maximum energy of $18.6 \mathrm{keV}$ and an average energy of $5.6 \mathrm{keV}$. Tritium produces a decay heat of about $0.324 \mathrm{watts} / \mathrm{gm}$. It decays by emitting an electron to form He-3. Tritium will be the primary radioactive contaminant in TFM\&C low-level waste streams.

Tritium will permeate or diffuse into almost all surfaces with which it comes into contact and will readily exchange with hydrogen-containing materials such as moisture, corrosion oxide products, oils and polymeric materials. Thus all systems that come into contact with primary tritium confinement systems (pipe, tank, etc.), such as liquid and gas coolants/heat transfer media, will eventually become contaminated with tritium.

Tritium contamination may be in the form of "fixed" or "removable" contamination. Fixed contamination (not removable by wiping) is in the form of a physical matrix into which tritium has diffused or dissolved, such as in a tank, piping or metal hydride bed. This means that tritium has actually diffused into the matrix of the container or metal components (metal films, piping, pump housings, etc.). Elemental tritium diffused into any material will diffuse back out when the original tritium source is removed. Fixed contamination such as metal tritide is very stable and can only be removed or desorbed by heating (for example, to about $650^{\circ} \mathrm{C}$ for titanium tritide) or isotopic exchange with protium or moisture. Removable or smearable contamination is generally in the form of an oxide, or tritiated water (HTO), or tritiated organic (oil, grease, etc.). Tritium oxide in tritium-processing equipment is unavoidable and will form any time tritium is exposed to air or moisture. It is formed by oxidation, or, more commonly, by isotopic exchange with elemental hydrogen in moisture.

In the TFM\&C facilities, most job control waste in the tritium processing and purification operations will contain removable tritium contamination. Failed tritium process equipment and maintenance parts will contain primarily fixed contamination.

\subsection{Waste Treatment and Disposal}

\subsubsection{Waste Treatment}

Treatment and disposal options for TFM\&C process wastes are summarized in Table 3. Waste streams in each treatment/disposal category are listed in Appendix E. While compaction only is a viable treatment for low-level waste, most RCRA wastes require some sort of stabilization of the final waste form. Wastes that may be either compacted or thermally destroyed (e.g., incineration) include most job control waste streams and water filters. The possibility of tritium-contaminated metal recycling should also be investigated by tritium Operations after startup of the facility, given that SRS has successfully worked with commercial vendors to recycle 
tritium-contaminated stainless steel from reactor heat exchangers by using it to make waste containers. Examples of wastes that require encapsulation are those that contain RCRA-listed heavy metals, such as lead. Tritium-contaminated liquid wastes may be incinerated, or, because of their small expected total volume, they may be stabilized and solidified for E-Area Vault disposal.

Table 2. Treatment/Disposal Options for TFM\&C Waste

\begin{tabular}{|c|c|c|c|c|}
\hline $\begin{array}{c}\text { Treatment/Disposal } \\
\text { Option }\end{array}$ & Waste Type & $\begin{array}{l}\text { Mass } \\
\mathrm{kg} / \mathrm{yr}\end{array}$ & $\begin{array}{l}\text { Volume } \\
\mathrm{m}^{3} / \mathrm{yr}\end{array}$ & $\begin{array}{c}\text { Avg Waste } \\
\text { Density } \\
\mathrm{kg} / \mathrm{m}^{3}\end{array}$ \\
\hline CIF Incineration followed by & Low-Level & 3,800 & 25.2 & 151 \\
\hline Stabilization of residue & $\begin{array}{l}\text { Mixed } \\
\text { Tritiated Oil } \\
\text { Hazardous }\end{array}$ & $\begin{array}{r}380 \\
90 \\
82\end{array}$ & $\begin{array}{r}2.5 \\
0.1 \\
0.091\end{array}$ & $\begin{array}{l}152 \\
900 \\
900\end{array}$ \\
\hline $\begin{array}{l}\text { Compaction for LAW Vault } \\
\text { disposal }\end{array}$ & Low-Level & 634 & 4.2 & 151 \\
\hline Direct LAW Vault Disposal & Low-Level & 2,625 & 5.9 & 445 \\
\hline Direct ILTV Vault Disposal & Low-Level & 2,560 & 4.1 & 624 \\
\hline $\begin{array}{l}\text { Package for storage and/or off- } \\
\text { site disposal }\end{array}$ & $\begin{array}{l}\text { Mixed } \\
\text { Hazardous }\end{array}$ & $\begin{array}{r}404 \\
0.9 \\
\end{array}$ & $\begin{array}{r}2.5 \\
0.001 \\
\end{array}$ & $\begin{array}{l}160 \\
900\end{array}$ \\
\hline \multirow[t]{3}{*}{ Other* } & Low-Level & - & - & - \\
\hline & Mixed & - & - & $\overline{-}$ \\
\hline & Hazardous* & 211 & 0.211 & 1000 \\
\hline
\end{tabular}

*Includes the following waste streams: Analytical Laboratory/Rad Con chemicals, filters, palladium membranes, etc. These are wastes for which treatment/disposal cannot a priori be defined. They are expected to constitute $<1 \%$ by volume and weight of TFM\&C process wastes. Treatment of analytical chemicals will be a function of the type of chemical; e.g., solid, liquid, acid, base, etc.

Personal Protection equipment (PPE) job control wastes would be most effectively treated using incineration followed by stabilization of the ash residue. Incineration combined with stabilization would reduce the waste volume by roughly a factor of 10 . If thermal treatment such as incineration is not used for PPE wastes, about half of TFM\&C wastes would receive only the most basic treatment (compaction) prior to disposal. This would achieve a volume reduction of 46. In addition to providing greater volume reduction, at least one study has shown incineration to be more economical. A recent comparison of waste compaction with off-site treatment and disposal versus on-site incineration conducted by SRS for the Consolidated Incineration Facility concluded that annual operating costs would be $\$ 20.3 \mathrm{M}$ for compaction and $\$ 13.5 \mathrm{M}$ for incineration (Ref. 12).

This PWA assumes that TFM\&C process waste streams will be treated and disposed of at SRS as much as possible and as economically as possible. Existing and planned treatment facilities for SRS are discussed in Appendix C. 


\subsubsection{Waste Disposal}

DOE Order 5820.2A requires that all DOE low-level waste (LLW) be disposed of at a DOE disposal facility. TFM\&C low-level waste is assumed to be disposed of at SRS in the EArea Vaults or in a future LLW disposal facility. Other DOE sites capable of receiving TFM\&C low-level wastes are the Nevada Test Site (NTS) and Hanford. NTS is a disposal site for lowlevel waste (see Section C3.2), but has no treatment capabilities, and none are planned. The Hanford Site is similar to SRS and possesses both treatment and disposal capabilities. A formal application and approval process must be completed before waste can be shipped to either of these two sites. No DOE facility is currently authorized to accept off-site mixed low-level waste (MLLW) for disposal; however, Hanford has accepted some shipments for storage on a case-bycase basis. Hanford, LANL, NTS, and SRS all have planned MLLW disposal facilities that are in the conceptual design phase and the preliminary stages of RCRA Part B permit applications. DOE currently allows mixed waste to be shipped to one permitted commercial facility, Envirocare of Utah, Inc., on a case-by-case basis. Other commercial waste disposal facilities capable of receiving and treating low-level and mixed low-level waste are DSSI and SEG in Tennessee. TFM\&C hazardous waste, per current SRS practice, could be disposed of at any DOE-approved commercial facility that would accept it.

\subsection{PWA Critical Assumptions}

The waste streams in this PWA are estimated based on the following critical assumptions. If these assumptions are changed materially, then the results presented here would need to be updated.

- TFM\&C incremental staffing in 233-H and 234-H is 70 persons; consisting of 28 shift workers and 42 day workers; 50 Tritium (including Operations, Engineering, Quality Assurance, Clerical, Training, Rad Con, Analytical Labs and Crafts) and 20 SRTC; with a maximum daytime staffing of 49 persons.

- TFM \&C tritium processing and support facilities in 233-H operate 24 hours a day, 7 days a week, 365 days a year.

- TFM\&C met lab facilities in 234-H and the R\&D tritium test manifold in 233-H are operated only during day shifts normally.

- Current SRS tritium waste generation rates in 233-H production processes and 232-H met labs provide valid baselines for projecting TFM\&C waste generation rates.

- Waste generation rates in $233-\mathrm{H}$ are proportional to production activity (i.e., the number of extractions projected for the CLWR-TEF, estimated at 14 extractions per year, 232-H Z-Bed Recovery Operations). It has been pointed by a reviewer of the PWA (Alexander) that annual rad waste generation rates do not necessarily correlate to production or extraction activities. This is quite plausible, as one does not engage in waste generating activities such as maintenance, housekeeping or decontamination unless there is a "lull" in production activities. Thus it would not be surprising to experience high waste generation in years with low production activities. However, the need for equipment maintenance and replacement of parts, certain process generated equipment and rad contamination level in waste are 
undeniably related to levels of production. Thus, for lack of a better method or assumption, waste generation rate estimated in this PWA will be scaled to production rates.

- Waste minimization initiatives will reduce job control waste for comparable activities by $50 \%$ by the time of TFM\&C facilities start-up.

- Personal protection equipment to be used in the TFM\&C will be incinerable. They will need to be manufactured out of non-polyvinyl chloride (PVC) materials in the future or be PVC materials currently being used on site. New PVC or banned PVC materials may not be reintroduced to the waste stream and change the SRS site loading of PVC. (Current tritium plastic suits, Tygon tubes and Pylox gloves in use all contain PVC.)

- The administrative control weight limit of a 21 "x 21 "x21" cardboard box container is $50 \mathrm{lb}$.

- For waste forecasting, most tritium processing equipment will be assumed to be constructed of stainless steel.

- Waste Treatment Volume Reduction Factors are assumed as follows:

$\begin{array}{ll}\text { Compaction } & 4 \\ \text { Supercompaction } & 6 \\ \text { Incineration } & 20 \\ \text { Stabilization } & 1 / 2 \text { (volume doubles) }\end{array}$

- Photographic waste from met lab operations and constriction craft will be minimized by using digital imaging. If conventional silver-based radiographs are taken into tritium-contaminated environments, they will be decontaminated for disposal as clean waste.

\subsection{Challenging Waste Streams and Waste Management Issues}

The TFM\&C facilities will generate several challenging waste streams which are only partially addressed in this PWA. Definitive resolution will require collection of additional data or development of new process technologies. These are described below.

\subsubsection{Tritiated Liquid Waste}

A number of liquid streams will be contaminated with tritium and cannot be disposed of easily: tritiated oil, tritiated cutting fluids, glovebox bubbler fluid and tritium-contaminated water. The treatment of choice for tritiated liquids containing acceptable levels of tritium is incineration. Alternatively, tritiated oil and glovebox bubbler fluid, due to their small anticipated volumes may be disposed as solid waste by stabilizing in an absorbent material and over-packed. This treatment and disposal method will take advantage of institutional control and the tritium decay half-life of 12.3 years, which will reduce tritium by about $99.6 \%$ in 100 years. However, this treatment and disposal method has not been used recently at SRS and an exemption to the EAV WAC may be required. Other strategies for addressing these wastes include reducing the concentration of tritium in contaminated cooling water by using once-through cooling and in bubbler fluid by more frequent 
change-out. Operational flexibility in dealing with these waste streams is increased. However, the waste volume will increase as a trade-off.

\subsubsection{Tritium Permeation and Quantification}

It is not possible to determine the tritium content in the bulk of a waste component based strictly on detected tritium off-gassing rates. Tritium will permeate or diffuse into almost all surfaces that it contacts and will readily exchange with hydrogen-containing materials such as moisture, corrosion oxide products, oils and polymeric materials. The current SRS Tritium Facilities waste characterization plan assigns nominal amounts of tritium to tritium-contaminated piping, flanges, and other miscellaneous standard equipment parts. This tritium will include both analytically determined tritium trapped in corrosion product oxide layers and tritium calculated to permeate into the metal matrix. It is important to use a proper degree of benchmarking for the TFM \&C process waste. Attaching a "nominal" value to each "type" of waste component, rather than analyzing each individually in detail, is cost-effective, but may be non-conservative. This methodology and use of nominal or average values is satisfactory for Curie brokering (tracking and management of radionuclide Curies from waste packages) to meet radionuclide limits and optimize capacity utilization in the E-Area Vaults. From an operational viewpoint, one should be prepared for a tritium "puff" release if such tritiated waste is compacted, due to the off-gassing and build-up of tritium into the waste bag from components containing potentially much higher than "nominal" amounts of tritium.

\subsubsection{TFM\&C Process Technology Uncertainties}

TFM\&C process waste streams will be process-specific. They will depend on what technologies, equipment and materials are adopted for the production process. For example, current RTF tritium confinement systems use catalyst and zeolite beds in stripper cleanup systems. (See Appendix A for a description of these processes). Z-bed regeneration and tritium recovery from the desorbed tritiated water may be achieved using either $\mathrm{Mg}$ beds or $\mathrm{U}$ beds (per existing 232-H Tritium Extraction Facility and 233-H Replacement Tritium Facility). The current baseline technology is to use $\mathrm{Mg}$ beds due to greater waste generation in preparing $\mathrm{U}$ beds. In either case, the $\mathrm{Mg}$ or $\mathrm{U}$ beds become spent and have to be replaced, resulting in waste $\mathrm{Mg}$ or $\mathrm{U}$ beds.

Potential alternative tritium recovery technologies are to use a regenerable iron bed or solid oxide electrolysis (under development at SRS), or a palladium membrane reactor (under development at Los Alamos National Lab).

\subsection{Waste Minimization Technologies and Process Development}

There are a number of opportunities in the TFM\&C processes for waste minimization by adopting new technologies under development. Some of these waste minimization technology and process development opportunities are discussed in the following sections.

\subsubsection{Palladium Membrane Reactor}

The palladium membrane reactor (PMR) can be used for the recovery of hydrogen isotopes from compounds such as water and methane. Successful development and deployment of this technology will eliminate the spent uranium or magnesium bed waste stream. The PMR consists of 
a shell-and-tube Pd-Ag diffuser with catalyst packed into either the shell or tubes of the diffuser. In the PMR, water is reacted with carbon monoxide to produce elemental hydrogen:

$$
\mathrm{H}_{2} \mathrm{O}+\mathrm{CO}=\mathrm{H}_{2}+\mathrm{CO}_{2}
$$

The hydrogen gas is removed using palladium-silver tubes or membrane. This technology has been under development at LANL for a number of years. It is being evaluated for deployment in the TFM\&C Project. It is also under consideration for use in the APT Tritium Separation Facility. A plant-configured prototype needs to be demonstrated with a dilute tritium mixture to obtain data on separation efficiency, the effect of prolonged operation on organic generation, and for equipment. sizing and design. The introduction of $\mathrm{CO}$ processing of zeolite bed to complete dryness, and disposition of $\mathrm{CO}_{2}$ must also be addressed. This process will discharge $\mathrm{CO}$ and $\mathrm{CO}_{2}$ to stack and produce a waste stream of failed PMR equipment.

\subsubsection{Solid Oride Electrolysis}

Solid Oxide Electrolysis represents an attractive alternative to uranium or magnesium beds and can be developed as an alternative or back-up technology to palladium membrane reactor technology. In Solid Oxide Electrolysis, high temperature, gas-phase water vapor is cracked by passage of a current through a solid electrolytic cell. The steam is decomposed into hydrogen and hydroxyl ions which are separated by a ceramic membrane. Hydrogen and tritium ions combine to form elemental hydrogen and tritium gases, which are returned to the primary process. Hydroxyl ions combine to form water and oxygen. Solid Oxide Electrolysis is particularly attractive because the oxygen stream produced is dry and clean, with very low tritium content, which may allow it to be discharged to the stack with minimal treatment. Solid Oxide Electrolysis would therefore reduce or eliminate the need to dispose of tritium-contaminated uranium/magnesium beds. This process will produce waste of failed equipment/components. This technology would reduce the number of line breaks, handling of uranium/magnesium bed waste, and the potential for personnel exposure.

\subsubsection{Tritium Getters}

The TFM\&C Tritium Process Stripping System (TPSS) is planning to utilize hydrogen/ tritium getter technology. This decision was based on a LANL study that evaluated a number of alternate technologies to the conventional oxidation-absorption technology: getters, diffusers (permeators), cryogenic adsorption, cryogenic distillation, cryopump, PMR and hollow fiber membrane. Getters were recommended by that study. The advantage of getter technology is avoidance of water generation, leading to reduced need for Z-bed recovery and generation of waste magnesium or uranium beds. To strip tritium from a process stream, two getters are used in series: a sacrificial SAES St909 getter that reacts with oxygen and cracks water to convert all hydrogen isotopes to the elemental form, followed by a SAES St198 getter that getters hydrogen as a hydride. When the St198 bed becomes saturated, it is heated to desorb the hydrogen isotopes, which then undergo isotopic separation.

Technical uncertainties remain with respect to St198 getter operation under SRS conditions and basic data is needed for design. SRS and LANL reached agreement in June 1997 to collect basic data for TPSS design and for designing a prototype process stripper system for a tritium demonstration (possibly in 232-H). Data will be collected using a getter system installed 
in the TSFF to determine performance under various conditions and to determine getter performance following regeneration.

\subsubsection{Advanced TCAP}

An advanced Thermal Cycling Absorption Process (TCAP) unit can be used to separate hydrogen isotopes and reduce tritium effluent discharge from the TFM\&C in place of cryogenic distillation. The current TCAP unit, used to achieve isotopic separation of tritium and deuterium, is adequate to produce a stackable stream from a low tritium concentration feed. However, advances in design will be needed to provide higher flow rates, improve heating/cooling operation, lower capital costs and lower amounts of tritium contamination in the stackable gas stream.

An advanced TCAP has two major improvements from the current design: 1) the Plug Flow Reverser (PFR) is replaced by an inverter column or filled with an improved packing material, and 2) improved heating and cooling mechanism. The use of an inverter column greatly increases the separation factor of the TCAP process. In addition, it makes recovery from process upsets much more reliable and predictable, especially for the stackable stream. However, the control mechanisms are different for the advanced TCAP. The control strategy would have to be developed and demonstrated on a prototype system. Evolutionary heating/cooling improvements are planned for the TFM\&C TCAP using glovebox nitrogen gas for cooling. A new TCAP concept under development will use a liquid cooled/electrically heated copper block.

\subsubsection{Hydride Bed Heating/Cooling Alternatives}

In the 233-H RTF, hydride beds are heated and cooled indirectly using nitrogen as a circulating heat transfer medium. Gradual permeation of tritium into the circulating nitrogen system has caused operating concerns in the RTF and created a waste management issue. The TFM\&C presents an opportunity for improving hydride bed heating/cooling technology to address this issue with a fundamental change in technology.

The current TFM \&C baseline design for hydride storage beds uses electric heaters for heating and glovebox nitrogen for cooling. One promising alternate heating and cooling technology for future TFM \&C hydride beds is the use of thermoelectric coolers with a boost from electric heating. Thermoelectric coolers are based on the Peltier-effect: a current applied to a junction of dissimilar metals produce a temperature gradient. They are now routinely used in portable refrigerators and for cooling computer CPU chips. Both technologies would eliminate the problem of tritium permeation into a "clean" coolant or heat transfer medium. Adoption of either technology in the TFM\&C requires some design effort and experimental verification.

\section{Conclusions}

The PWA has identified and quantified twelve potential radioactive process waste streams. Several of the potential TFM\&C hazardous and mixed low-level waste streams identified in this PWA and may be avoided altogether by product substitution or greatly reduced by inventory material control into the facility. All low-level radioactive waste streams from TFM\&C tritium processing operations are expected to meet the current WAC for disposal in the EAV. 


\section{Acknowledgment}

The authors wish to express our appreciation for review of this report and constructive comments provided by J. Alexander, M. Hayes, A. Poore, P. Rowan, and J. Santos. The authors also wish to thank the following for providing data used in this report: J. Alexander, R. Rabun, and R. Rhodes.

\section{References}

1. SNL, "Accelerator Production of Tritium Project Process Waste Assessment," SAND94-2217, UC-721, September 1995.

2. SNL, "Accelerator Production of Tritium Programmatic Environmental Impact Statement Input Submittal," SAND93-2094, November 1, 1993.

3. APT Programmatic Environmental Impact Statement Input Submittal, Rev. 1, May 101993.

4. Wilson, Brad, "Tritium Facilities CY95 Waste Minimization Plan," NMP-STE-95-0035, April $24,1995$.

5. WSRC, "Defense Program Division Low Level/Mixed Waste Certification Plan," WSRC-IM-9526, Rev. 1, December 14, 1995.

6. WSRC, "Pre-Conceptual Design Package for the Commercial Light Water Reactor Tritium Extraction Facility," M-CDP-H-00017, June 28, 1996.

7. SNL conversation with Luke Bartlein of the TSTA facility, April 26, 1994.

8. LANL, "Tritium Systems Test Assembly Final Safety Analysis Report."

9. L. K. Heung et al, "Tritium Confinement in a New Tritium Processing Facility at the Savannah River Site", Fusion Technology, Vol 21, March 1992.

10. Theodore Motyka, "The Replacement Tritium Facility", Fusion Technology, V. 21, March 1992.

11. M S. Ortman, et al, "Tritium Processing at the Savannah River Site: Present and Future", J. Vac. Sci. Technol., A 8 (3), May/Jun 1990.

12. H. L. Pope, C. McVay and T. Holm-Hansen, "A 'Fresh Look' at a U. S. Department of Energy Mixed Waste Incinerator," 1994 International Incineration Conference, Houston, TX, May 9-12, 1994.

13. WSRC, “CLWR-TEF Conceptual Phase Key Assumptions,” Rev. August 5, 1996.

14. WSRC, E-Mail Message, A. O. Delley to J. R. Puruker, "Overpack and Transport Cask Design," August 1, 1996.

15. WSRC, "Tritium Facility Modernization \& Consolidation Project S-7726 Baseline," May 22, 1997.

16. Rabun, R.L., "TFM\&C Projected Estimated Waste Generation," E-Mail to A. Bhargava, dated $10 / 21 / 97$. 


\section{APPENDIX A \\ Tritium Facilities Modernization \& Consolidation Project Processes and Operations}

Under the Tritium Facility Modernization \& Consolidation (TFM\&C) Project (S-7726) at the Savannah River Site, all tritium processing operations in Building $232-\mathrm{H}$, with the exception of extraction and obsolete/abandoned systems, will be moved to $233-\mathrm{H}$. These operations include hydrogen isotopic separation, loading and unloading of tritium shipping and storage containers, tritium recovery from zeolite beds, and stripping of nitrogen flush gas to remove tritium prior to stack discharge. The scope of the TFM\&C Project will also provide for a new R\&D tritium test manifold in 233-H and for relocating 232-H Materials Test Facility flow tester, dark room, environmental chambers and metallurgical laboratories (met labs) to 234-H. The met labs are used to examine failed tritium processing equipment and burst-tested reservoir parts. Environmental chambers and flow tester are associated with reservoir component quality assurance program, also referred to as the Life Storage Program. The new TFM\&C facilities will also process tritiumcontaining gases from the Commercial Light Water Reactor - Tritium Extraction Facility (Project S-6091) to produce tritium product of the desired purity

Operation of the TFM\&C facilities will generate waste streams of materials that cannot be recycled or reused, including system components which fail through usage or exposure to harsh environments, or which must be replaced due to aging, degradation and obsolescence. Other waste streams are generated in decontamination and maintenance operations, which produce significant volumes of job control waste consisting of kraft paper, plastic sheets, shoe covers, gloves, plastic suits, and solvent wipes.

There are two points to keep in mind with respect to waste generation and management. First, since purified tritium is the only product of the TFM\&C, all other process materials introduced into the facility will potentially end up as waste, either during its operational life or when it is to be decontaminated and decommissioned. Thus, the simpler the TFM\&C processes and the fewer operations conducted, the smaller will be the waste generation. The second important point is that treatment and disposal options are dependent upon the characteristics of the waste. TFM\&C facilities will deal with only one source of radioactive contamination: tritium.

As TFM\&C facility operations and processes are discussed in this appendix, process outputs and system components that result in waste streams are identified. Since the TFM\&C tritium processing facilities to be located in Building 233-H are closely interfaced with processes in both the new CLWR-TEF and the existing tritium loading and processing facilities in 233-H, some of the interfaced operations will also be described to add clarity. The proposed processes and conceptualized operations for the TFM\&C Project tritium processing facilities are organized into the following sections:

A1. Tritium/Praduct Processing

A1.1 Tritium Purification Processes

A1.2 Tritium Separation

A1.3 Tritium/Product Storage and Delivery 
A2. Tritium Process Confinement and Clean-up Systems

A2.1 Confinement Systems

A2.2 Tritium Clean-up and Recovery Systems

A2.3 Confinement Monitoring Systems

A3. Tritium Process Stripping

A4. Metallurgical Lab/Life Storage Program Operations

A5. Tritium Analysis and Accountability
A5.1 HP and Radiometric Lab

A5.2 Mass Spectrometry and Accountability

A5.3 Low-level Waste Assay

A6. Balance of Plant Facilities

A6.1 Electrical Power

A6.2 Steam

A6.3 Domestic Water Supply

A6.4 Sanitary Wastewater

A6.5 Process and Building Chilled Water

A6.6 Process Wastewater

A6.7 Storm Sewer System

A6.8 Fire Protection

A6.9 Inert Gas Systems

A6.10 Plant, Instrument and Breathing Air

A6.11 Building HVAC

A6.12 Process Heating/Cooling

A6.13 Control Room/Integrated Control System

A6.14 Offices and Change Rooms

A6.15 Safeguards and Security

A6.16 Emergency Services

A6.17 Communication Services

A6.18 Maintenance Facilities

A6.19 Balance of Plant Waste Streams

A simplified schematic of the TFM\&C tritium processes is shown in Figure A1. 


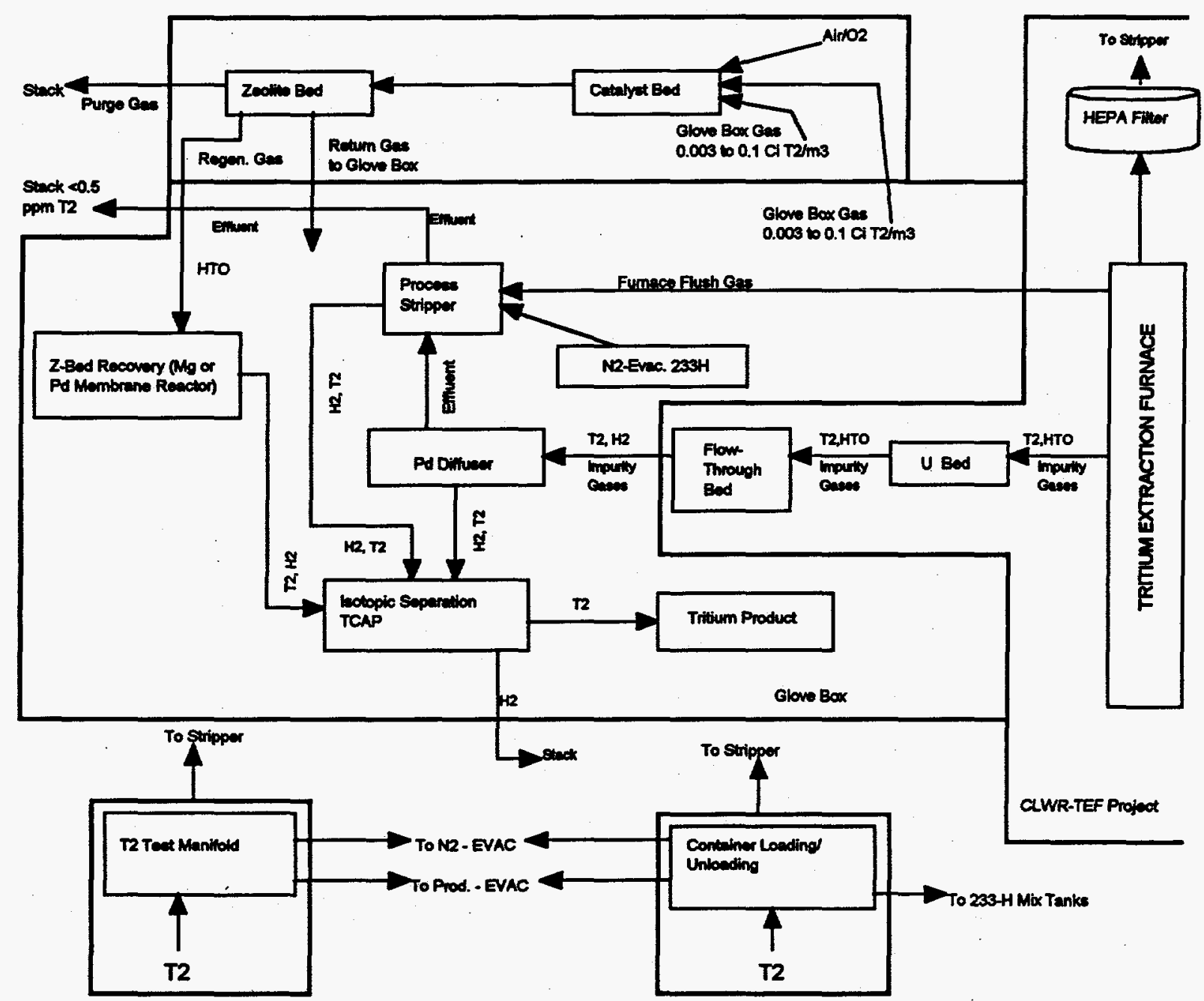

Fig. A-1 TFM \& C Tritium Separation And Purification Process Schematic, Tritium Test Manifold and Container Loading/Unloading. 


\section{A1. Tritium/Product Processing}

The tritium product gas extracted by the Tritium Extraction Facility furnace is converted to elemental form by a uranium bed (Al.1), and purified by a flow through bed (A1.2) to remove impurity gases from the hydrogen isotope gases (Tritium Purification). Conversion of tritium oxide to elemental form and flow through bed operations are part of the CLWR-Tritium Extraction Facility. In the TFM\&C facilities, the tritium-contaminated impurity gases undergo further purification using a palladium diffuser (A.1.3) The hydrogen isotope gases then undergo isotopic separation (Tritium Separation) to produce tritium product of the desired quality. The tritium product is stored and delivered to the $233-\mathrm{H}$ tritium loading facility, as needed.

\section{A1.1 Tritium Purification Processes}

Tritium purification consists of:

- Conversion of hydrogen isotopes to the elemental form (CLWR-TEF)

- Removal of inert impurity gases by Flow Through Bed (CLWR-TEF)

- Removal of inert impurity gases by Diffuser

\section{A1.1.1 Conversion of Hydrogen Isotopes to Elemental Form (CLWR-TEF)}

The tritium-rich furnace gas contains moisture (hydrogen oxides) from the Tritium Producing Burnable Absorber Rods (TPBARs) and ambient air humidity that must be converted to elemental hydrogen isotopes for further processing and purification. These oxide forms of hydrogen are converted or "cracked" to elemental hydrogen isotopes using an uranium or magnesium bed. At elevated temperatures, the heated beds of depleted uranium or magnesium react with hydrogen oxide to form uranium or magnesium oxide and release elemental hydrogen isotopes. After cracking, the process gas is cooled and processed through a zeolite bed to remove unreacted hydrogen oxides (waters).

\section{A1.1.2 Removal of Impurity Gases by Flow Through Bed (CLWR-TEF)}

As in 233-H, the CLWR-TEF will process cracked furnace extraction gas by using a Pd-kieselguhr packed hydride bed to separate impurity gases from hydrogen isotopes. Following a cold absorption cycle to load hydrogen onto the hydride bed, the bed is heated to desorb the high-purity hydrogen isotopes. The hydrogen isotope stream is then drawn through the bed by a mechanical pumping system to tanks or hydride storage beds in the product evacuation area.

\section{A1.1.3 Removal of Impurity Gases by Diffuser}

In the TFM\&C, CLWR-TEF Flow Through Bed effluent stream undergoes additional purification by the Inert Separation system catalytic purifier and diffuser. In the diffuser, hydrogen isotopes are separated from $\mathrm{He}-3$ (caused by tritium decay), $\mathrm{He}-4, \mathrm{~N}_{2}$ and other impurity gases by permeation of the hydrogen isotopes through a palladium-silver (Pd-Ag) alloy tube. Hydrogen isotopes diffuse through the heated tube wall into the shell and are evacuated to storage and isotopic separation. All other gases and by-products $\left(\mathrm{He}-3, \mathrm{Ar}, \mathrm{N}_{2}\right.$, etc.) remain on the tube side and are drawn through the diffuser tubes by a vacuum pumping system to storage tanks and to a He-3 Recovery System. Based on SRS plant experience, the Pd-Ag diffuser will eventually leak, 
usually around the weld joints (stainless steel to Pd-Ag transition joints), and have to be replaced from time to time.

The product evacuation area consists of hydride storage beds, tanks and high vacuum headers which are connected to several of the process systems in the TFM\&C to remove hydrogen isotopes from the purification processes. The product evacuation area is also used to evacuate hydrogen isotopes from equipment in preparation for maintenance and to store hydrogen isotopes in the hydride storage beds until needed as feed to the Purification System.

Tritium Purification also processes tritium gas mixtures recycled from the 233-H Replacement Tritium Facility (RTF) and the Z-Bed Recovery System (A4.2). Tritium Purification equipment consists of Pd-Ag diffusers, hydride beds, tanks, piping, vacuum pumps and associated equipment housed in nitrogen-blanketed gloveboxes.

\section{A1.2 Tritium Separation}

The TFM\&C will use Thermal Cycling Absorption Process (TCAP) to isotopically separate $\mathrm{T}_{2}$, $\mathrm{HT}$, and $\mathrm{H}_{2}$. During normal operations, the stack gas exhausted to the atmosphere should contain less than 5 parts per million tritium.

Certain metals and alloys which react rapidly and reversibly with hydrogen at room temperature and atmospheric pressure to form metal hydride compounds represent a technology ideally suited to the handling and processing of tritium. The hydriding/dehydriding reaction can be used as a basis for the storage, pumping, compression, purification and separation of hydrogen isotopes. One of the most important advantages of using hydride technology in tritium processing is the compact size of the hydride equipment, due to the fact that the volumetric density of hydrogen in typical hydrides is greater than that of liquid or solid hydrogen. This allows hydride beds to be installed in gloveboxes or hoods at locations where only minimal space is available. Cost savings are achieved through reduced numbers of gloveboxes and the overall size of the processing facility. Other benefits of using hydride technology for tritium handling applications are improved safety during storage of tritium in the hydride form and ease of operation due to the absence of moving parts.

TCAP (Thermal Cycling Absorption Process), based on metal hydride technology, is a semicontinuous chromatographic separation process used in the RTF production process to separate deuterium-tritium mixtures at moderate temperatures. Invented at the SRTC, TCAP is a compact and highly efficient hydrogen isotopic separation system that uses Pd/kieselguhr as the packing material. During hydrogen absorption the TCAP beds are cooled using forced flow of glovebox atmosphere nitrogen gas. Electric heaters are used for heating during desorption. Very high purity tritium can be produced. The TFM\&C protium-tritium separation is easier to achieve than deuterium-tritium and should be easily accomplished by the TCAP.

\section{A1.3 Tritium/Product Storage and Delivery}

Tritium product is stored in tanks and hydride beds. Hydride beds possess significant capacity advantages over tanks. Certain hydride materials based on lanthanum-nickel-aluminum compositions ( $\left.\mathrm{LaNi}_{s_{-x}} \mathrm{Al}_{\mathrm{x},} \mathrm{x}-0.3-0.75\right)$ and sometimes referred to as "LANA", retain the He-3 decay product of tritium, to desorb high purity tritium gas. LANA storage beds are assumed to have a service life of 5 years, basod on anticipating that helium retention would eventually saturate 
the LANA bed material. Tanks are used for tritium storage, to provide samples for compositional analysis and for metering gas transfers (accountability). Tritium product will be delivered to the 233-H mix tanks via pipeline.

The TFM\&C Project will provide facilities to unload, recover and store tritium and other process gases from hydride storage vessels (HSVs), hydride transport vessels (HTVs) and product vessels (PVs). TFM\&C facilities will also load HTVs and PVs.

Wastes from tritium recovery systems are discussed in Appendix B under the following waste streams:

\author{
Job Control Waste (H-3) \\ Non-hazardous Process Equipment (H-3) \\ Non-hazardous Solvent \\ Non-hazardous Tritiated Oil \\ Diffuser \\ Catalytic purifier
}

\title{
A2. Tritium Process Confinement and Clean-up Systems
}

The TFM\&C facilities will make use of the latest technology to enhance operational safety, ensure material safeguards and security, and prevent tritium losses to the environment. Past experience at SRS tritium facilities indicates that many significant waste streams do not come from the actual extraction and processing of tritium, but rather from maintenance activities. Prior to RTF, in the old 234-H loading facility and currently in the 232-H tritium extraction facility, maintenance operations utilize an "open" hood, requiring the use of protective clothing. This "plastic suit work" added significantly to the amounts of low-level waste generated. It is expected that all TFM\&C tritium process systems except for met labs are to be housed in enclosures designed to contain tritium leaks and allow recovery of the tritium. When processes are contained in gloveboxes, routine maintenance operations can be performed through glovebox ports without the use of a fullbody plastic suit. These enclosures are maintained under negative pressure to prevent leakage of contaminated gases and can be filled with a blanketing gas atmosphere such as nitrogen to minimize the formation of tritium compounds that are prone to skin absorption (tritiated water or oil). Confinement box gases are circulated to a tritium stripping or clean-up system, which removes tritium from the effluent gas. A Z-Bed recovery system then recovers tritium from the stripper system. Implementation of these design features is expected to significantly reduce routine tritium releases from the incremental TFM \&C operations to less than historical tritium releases from the existing 232-H operations being replaced.

\section{A2.1 Confinement Systems}

Confinement systems in the TFM\&C facilities protect the environment and operating personnel from tritium release, radionuclide contamination and tritium uptake. The confinement systems are customized around individual processing modules.

Tritium processing equipment will be confined in gloveboxes or hoods. Tritium processing equipment includes mechanical pumps, valves, tanks, magnesium beds, hydride storage beds, hydride pumps, hydride separators, Pd-Ag diffusers, TCAP, tritium process stripper, glovebox 
stripper systems, tritium recovery systems and a Z-bed recovery system. The TFM\&C building HVAC will be sized to provide 150 linear feet per minute air velocity at glovebox and hood openings during normal operation and 200 linear feet per minute during open glovebox maintenance.

Acceptable tritium levels in processing areas are typically $<10^{-5} \mathrm{Ci} / \mathrm{m}^{3}$ in the rooms, or around the instrument sensitivity of Kanne chambers. Inside process gloveboxes, tritium levels are typically $<10^{-1} \mathrm{Ci} / \mathrm{m}^{3}$ during normal operation. Glovebox gases are continuously processed through a tritium stripper system to remove tritium and other impurities.

\section{A2.2 Tritium Clean-up and Recovery Systems}

The TFM \&C glovebox clean-up or stripper systems remove tritium from the atmospheres of equipment enclosures such as gloveboxes and other confinements systems. Normally, the Primary Stripper cleans the glovebox gas and circulates it back to the gloveboxes. Tritium concentration in most existing 233-H glovebox atmospheres is typically less than about $0.01 \mathrm{Ci} / \mathrm{m}^{3}$, or about $5 \mathrm{ppb}$ tritium. On detection of a high tritium level in a glovebox, for example, due to an accidental tritium release, the glovebox atmosphere gas from that glovebox is diverted to a Secondary Stripper system for expedited clean-up. The TFM\&C Primary and Secondary tritium stripper systems both use heated catalyst beds to oxidize hydrogen isotopes and their compounds to water. The water is then trapped in a bed of zeolite molecular sieve. Excess glovebox gas needing to be removed to control glovebox pressure is directed to the existing 233-H Purge Stripper for additional stripping prior to stack discharge. (The TFM\&C Project will providing for upgrading the capacity of the existing 233-H Purge Stripper)

Tritium is a relatively benign radionuclide which becomes a much more significant hazard if absorbed inside the body through an uptake, where it can become incorporated as part of water or organic compounds. Exposure to tritium oxide (HTO) through inhalation or skin exposure is the most important type of tritium exposure because it results in the distribution of HTO throughout the soft tissue of the body. If tritiated hydrogen (HT) is inhaled, only a fraction is dissolved in the blood, and the rest is exhaled. Another hazard associated with tritium is its ability to diffuse into many substances, be converted into organic compounds, diffuse back to the surface, contaminate the surface, and be absorbed through the skin of a person touching the surface. Gloveboxes are blanketed with nitrogen to minimize the formation of HTO. However, air inleakage through the gloves and around glovebox panels/gaskets is unavoidable and has been found to be the major source of water trapped in the 233-H stripper systems.

Tritium, protium, nitrogen, oxygen, and water are the primary gas impurities in a blanketed glovebox system. Tritium comes from leakage of the process equipment. Protium comes mainly from the moisture in the air which leaks into the glovebox or permeates through the gloves. Oxygen comes from air leaking in and permeation through the gloves. The oxygen level in a glovebox is monitored and controlled at less than $1 \mathrm{vol}$ \% by adjusting the purge rate. More than $99.9 \%$ of the moisture in the system is expected to be from glovebox leaks and permeation through the gloves. All of this water is adsorbed in zeolite beds, along with a very small amount of tritiated water. 


\section{Z-Bed Recovery System}

Unless the zeolite beds are designed and operated as single-use disposable beds, they need to be regenerated periodically by heating and flushing with a sweep gas. The recovered water is then processed to recover tritium and other hydrogen isotopes. The baseline TFM\&C Z-Bed recovery technology uses a magnesium bed (RTF) to decompose water to produce elemental hydrogen isotopes, which undergo further processing to recover tritium. The spent magnesium bed needs to be replaced periodically and becomes a waste. Alternative recovery technologies include using a palladium membrane reactor or solid oxide electrolysis. A regenerable iron oxide bed may also be used, but regeneration of the iron oxide uses hydrogen to produce a water vapor stream that is still contaminated by tritium, though to a much lesser extent. The first two technology process development opportunities are discussed in Section 5.6 of the main text of this report.

\section{A2.3 Confinement Monitoring Systems}

Tritium air monitors and other instruments monitor the atmosphere in glovebox and confinement systems to ensure that they are performing to design specifications. These instruments may include oxygen analyzers (e.g., Teledyne Oxygen Sensor being in Building 233-H), tritium monitors (ion chambers or Kanne chambers), hydrogen monitors, continuous air monitors, beta-gamma radiation detectors, temperature sensors, and pressure controllers and gauges. Using conventional technology as in 233-H, the gloveboxes will be equipped with bubbler systems to provide catastrophic pressure relief and to seal gloveboxes against air intake.

Wastes from tritium process confinement and clean-up systems and monitors are discussed in Appendix B under the following waste streams:

Job Control Waste (H-3)

Non-hazardous Process Equipment (H-3)

Uranium/Magnesium Beds

Glovebox Bubbler Fluid

Non-hazardous Tritiated oil

Hydride/Catalyst/Zeolite Beds

Tritiated Water

Teledyne Oxygen Sensor Micro-fuel Cells

Palladium/Electrolysis Membrane (If U or Mg Beds are not used)

\section{A3. Tritium Process Stripping}

Impurity gases to be stacked such as nitrogen, argon, ammonia and methane may contain small quantities of tritium and usually cannot be released without treatment. The tritium process stripper system (TPSS) in the TFM\&C Project will remove tritium from several such gaseous streams so that they may be directly discharged to the stack without further treatment. The feed streams include: 1) the 233-H Contaminated Nitrogen (existing), 2) the Flush Gas Evacuation from the proposed Tritium Extraction Facility, and 3) the HT Inert Separation (diffuser) byproduct stream from the TFM\&C Project. The tritium process stripper shall be designed to process 220,000 liters per year of gaseous streams that contain $\leq 2 \mathrm{vol}$. $\%$ hydrogen isotopes and $\leq 0.25 \% \mathrm{~T}$. The nonhydrogen process gases will include nitrogen, oxygen, water, helium (both $\mathrm{He}-4$ and $\mathrm{He}-3$ ), argon and, possibly, organics. The stripped effluent gases should contain $\leq 5 \mathrm{ppm}$ tritium. The 
discharge from the process stripper will be piped to the 233-H ventilation exhaust system upstream of all stack monitoring systems. If the discharge gas contains $>5$ ppm tritium, the discharge may be circulated through the TPSS until the desired tritium level is achieved. Stripped tritium and other hydrogen isotopes are recovered and sent to storage and processing for tritium enrichment.

\section{A4. Metallurgical Lab/Life Storage Program Operations}

The MTF met labs are used to conduct failure analysis of tritium process equipment and to examine burst tested reservoir specimens. Equipment include mechanical band saw and wheel cutters, polishers, and etchers for both clean and contaminated metallography. The met labs also house scanning electron microscopes, a scanning auger microprobe, and miscellaneous microscopes.

In the Life Storage Program, production and prototype reservoirs stored in secondary containers and subject to environmental conditioning are monitored periodically for reservoir container integrity. Periodically, reservoirs are removed for unloading tritium, function testing and metallurgical examination. The flow tester is used to obtain gas flow measurements on function tested reservoirs.

The existing tritium test manifold in 232-H is a stand alone facility used by SRTC/MTF personnel to study the effects of tritium on various materials. The new tritium test manifold in $233-\mathrm{H}$ will be connected to the existing 233-H infrastructure, but will perform similar tests.

Waste generated in the met labs, flow tester operations and Life Storage Program include decontamination waste of wipes, discarded metal and reservoir specimens, tritium-contaminated cutting fluid, and tritium-contaminated low level job control waste of gloves and wipes.

\section{A5. Tritium Analysis and Accountability}

\section{A5.1 Radiological Control (Health Protection) and Radiometric Laboratory}

Radiological Control (Rad Con), historically known as Health Protection, is responsible for conducting routine smears at SRS to monitor tritium and beta-gamma contamination in TFM\&C office and process areas. Scintillation and other counters are routinely used for this function. Smear samples are immersed in liquid scintillation cocktails to leach out tritium and produce detectable scintillations for measurement. Counting instruments must be calibrated periodically. using standard mixtures such as P-10 counting gas. Rad Con also provides support for facility maintenance operations in contaminated process areas, sniffing of packaged waste boxes, and decon operations.

Gas monitoring systems such as continuous air monitors (CAM's), Kanne monitors, ion chambers, and personnel protection monitors such as PCM-1B and hand-held radiation count rate meters (CRMs) are also the responsibility of Rad Con.

Rad Con operations will generate low-level waste and discharge chemical vapors to a chemical hood. Scintillation cocktails from analysis are discharged into a laboratory sink that feeds to the H-Area Effluent Treatment Facility. 
No new Rad Con and radiometric labs are being added as part of the TFM\&C Project. Existing facilities in buildings $233-\mathrm{H}$ and $234-\mathrm{H}$ will be used. Rad con activities and associated waste generation will be additive to current levels in these two buildings.

\section{A5.2 Mass Spectrometry and Accountability Measurement Lab}

Analytical Laboratories conduct routine analyses of process gas samples using mass spectrometry (mass spec) or gas chromatography to determine the gas composition needed for tritium accountability. Capillary lines are run from process sampling points and tanks to the mass spec lab. They must be evacuated and flushed between analyses. Sample bottles may also be used to take samples for analysis at the mass spectrometer. Sample bottles are reusable, but their outer surfaces must be decontaminated if they are removed from glovebox confinement.

Since tritium is a special nuclear material, periodic inventories must be undertaken. All tritium inventories in process/product tanks, hydride and other beds and process piping must be accounted for. Tritium in tanks is determined using the mass spec composition measurement and the tank pressure, volume and temperature (P-V-T-C). Tritium in hydride beds is determined using a flowing-gas calorimetric method and calibration data. Tritium product in small transportable containers may be determined using conventional calorimetry.

Non-routine radiological analyses are expected to be conducted in existing SRTC or Central Analytical Laboratory Facilities.

Waste from the TFM\&C mass spectrometry and accountability analytical laboratory may contain both radioactive and hazardous components, and is addressed in Appendix B under the waste stream called Analytical Laboratory Wastes.

\section{A5.3 Low-level Waste Assay}

Current SRS practice requires all identifiable radioactive waste streams to be covered by approved waste characterization plans prior to disposal. Packaged tritium waste in 21"x21"x21" cardboard waste boxes and 55 gallon waste drums must be assayed to ensure that the waste stream characteristics are as projected in the waste characterization plans.

Assay instrument calibration at SRS may also involve using a radioactive source. Assay instrument results are printed out as QA records and used as input to the solid waste manifest. Waste assay instrumentation is usually located near the Storage/Staging Area for B-25 waste boxes.

Wastes from tritium analysis and accountability operations are discussed in Appendix B under the following waste streams:

Job Control Waste (H-3)

Non-hazardous Process Equipment (H-3)

Analytical Laboratory/Rad Con Chemicals

Reservoir Fragments

Tritiated Water and Aqueous Solutions

Cutting Fluids 


\section{A6. Balance of Plant Facilities}

TFM\&C balance-of-plant support facilities are described in this section. In most cases, existing support facilities in buildings $233-\mathrm{H}$ and $234-\mathrm{H}$ will be used and upgraded as necessary. A few new support facilities are being added as part of the TFM\&C Project. The increased operations of the 233-H and 234-H balance-of-plant facilities to support TFM\&C process and met lab facilities will generate incremental waste, as discussed below. Unless otherwise noted, the descriptions below will refer to changes in building $233-\mathbf{H}$.

\section{A6.1 Electrical Power}

Additional electrical power is needed to operate TFM\&C process equipment (pumps, valves, etc.), lighting, computers, controllers, Rad Con equipment and the building HVAC systems. Building electrical power for routine use is tapped into the existing SRS power grid. The TFM\&C Project will provide for a new 234-H Motor Control Center (MCC) equipment building.

Standby electric power supply will be needed to provide short-term back-up power to support system loads in the event of a temporary failure of the electrical power supply. Standby power is provided by existing $750 \mathrm{~kW}$ diesel generators and battery-based $75 \mathrm{kVA}$ uninterruptible power supplies (UPS). The UPSs are designed to sustain TFM\&C safety functions through the momentary power loss that occurs as the energy/standby source comes on-line following a loss of normal power. Burning of diesel during testing or prolonged operation will generate a waste air stream containing carbon dioxide, carbon monoxide and unreacted fuel. Servicing of the diesel and UPS will generate waste from replacement of non-working equipment parts such as switches and batteries.

Electric power consumption load for the TFM\&C facilities in 233-H is estimated to be $776 \mathrm{kVA}$. The connected load is $970 \mathrm{kVA}$.

\section{A6.2 Steam}

Steam is needed to provide heating for $233-\mathrm{H} / 234-\mathrm{H}$ building $\mathrm{HVAC}$ all year round. Steam tracing may also be used to prevent freezing of process lines outside of the building. The TFM\&C incremental steam supply is assumed to connect to an existing steam header. Only low-quality ( $<200$ psig) steam is assumed to be necessary. Maintenance of the steam line will result in replacement of steam traps, valves, flow controllers and pressure gauges.

Steam usage requirement for the incremental TFM\&C facilities in $233-\mathrm{H}$ and $234-\mathrm{H}$ have not been determined.

\section{A6.3 Domestic Water Supply}

Domestic water is used in the 233-H/234-H/249-H office areas, lunchroom, change rooms and rest rooms. The domestic water supply will tap into the existing plant system. Additional filtration may be needed near the connection point. Filters would require periodic replacement or cleaning.

The domestic water usage will be based on operating staff level. TFM\&C incremental demand is estimated to be about $1.3 \times 10^{6} \mathrm{gal} / \mathrm{yr}$ or $4,900 \mathrm{~m}^{3} / \mathrm{yr}$ of domestic water, based on an incremental staffing of 70 persons and use of 1,500 gallons per person per month. Domestic water supply may also be used to supply the process water and fire water tanks for the TFM\&C. These would be 
one-time demands with an occasional need for make-up water, assuming process water would be re-circulated. If a cooling water tower is needed to support the TFM\&C facilities, domestic water will be used, as for existing cooling towers. The estimated demand would be $10 \mathrm{gal} / \mathrm{min}$ or $4.5 \mathrm{x}$ $10^{6} \mathrm{gal} / \mathrm{yr}$ for $85 \%$ availability ( 365 days $\times 0.85$ ).

\section{A6.4 Sanitary Wastewater}

Used domestic water becomes sanitary wastewater. All 233-H/234-H/249-H sanitary wastewater (sewerage) will be piped and pumped to a centralized Sanitary Wastewater Facility for treatment and release to the environment in accordance with the SRS National Pollutant Discharge Elimination System (NPDES) permit.

As with the domestic water usage, the incremental annual sanitary wastewater generated by TFM\&C personnel is estimated to be $4,900 \mathrm{~m}^{3} / \mathrm{yr}$.

\section{A6.5 Process and Building Chilled Water}

Chilled water is used for cooling the building HVAC and for process cooling. Process cooling may include cooling of stripper zeolite beds and glovebox atmosphere gas. Hydride storage beds and the TCAP system also require cooling of the nitrogen gas heat transfer medium. This type of cooling system is currently used for hydride beds in $233-\mathrm{H}$, however, consideration is being given in this project to implementing direct water cooling of hydride beds as an alternative. Process chilled water is also needed for Inert Separation, container loading/unloading and the tritium test manifold.

Process and building chilled water is usually re-circulated and reused. The TFM\&C facilities in 233-H are estimated to need two 60 -ton chiller water units and three $72 \mathrm{gpm}$ pumps. To ensure efficient operation, the water chemistry must be properly maintained and particulates such as clay and corrosion products removed. De-ionized and/or filtered domestic water may have to be used for the cooling tower make-up.

Waste streams generated by maintenance of these systems include filters, Type R-22 refrigerant, expired chemicals and bio-cides.

\section{A6.6 Process Wastewater}

Process wastewater is collected and sampled before discharge to the liquid Effluent Treatment Facility in H-Area or to the Tritium stormwater outfall. Sources of process wastewater include process cooling water slip streams, fluids collected in the floor drains in potentially contaminated areas, and Analytical Laboratory sinks where scintillation cocktails are discharged.

The incremental TFM\&C process wastewater generation rate is estimated to be 500 gallons or 1.9 $\mathbf{m}^{3}$ per year.

\section{A6.7 Storm Sewer System}

The existing storm sewers collect, confine and channel the following non-radioactive liquid effluents from the 233-H/249-H/234-H buildings: rainfall from building roof drains and parking areas, non-process cooling water (e.g., cooling water used for breathing air compressor), cooling tower blowdown, steam condensate, discharge from the chiller makeup water expansion tanks and building floor drains. The 233-H/249-H/234-H Storm Sewer System collects these effluents and 
discharges to the Outfall H-002 in H-Area. The storm sewer effluent is sampled and analyzed before discharge at Outfall, as required by the NPDES permit.

Since buildings 233-H/249-H/234-H are not being enlarged, there is no incremental demand on the existing Storm Sewer System due to the TFM\&C Project.

\section{A6.8 Fire Protection}

TFM\&C facilities in 233-H and 234-H will be provided with fire protection water systems and fire extinguishers. The fire protection water system will tap off the domestic water supply system.

Inadvertent discharge of fire protection water or planned discharge during testing is collected and disposed as process wastewater. Discharge of fire extinguishers will result in discharge of fumes and gasses to the building HVAC and require clean-up using rags and absorbent wipes.

\section{A6.9 Inert Gas Systems}

Inert gas systems include liquid nitrogen, low pressure nitrogen, instrument nitrogen, process flush nitrogen or hydrogen, liquid helium, helium, and argon gas.

Low-pressure nitrogen for blanketing TFM\&C gloveboxes will be provided from liquid nitrogen storage tanks and a vaporizer system. Higher pressure nitrogen, hydrogen and argon will be supplied from compressed gas cylinders. Compressed gas cylinders are generally located in clean areas and gases are piped into the process areas. Localized use of liquid nitrogen and liquid helium will be in portable dewars.

Compressed gas cylinders are reusable and sent back to the vendor for refill. Cylinders reaching the end of their useful lives are generally treated as sanitary waste. During operation, pressure regulators, valves, fittings and tubing may need to be changed out as sanitary waste.

\section{A6.10 Plant, Instrument and Breathing Air}

Compressed instrument air is needed to operate instruments, solenoid valves and other controllers. Breathing and cooling air is supplied to persons conducting plastic suit operations.

Compressed instrument and breathing air may be supplied by a portable compressor or compressed air cylinder bottles. Instrument air is usually passed through a moisture dryer, a lubricator and a pressure regulator. The dryer is reusable, but the drying agent breaks down and may need to be replaced or made up periodically. During operation, pressure regulators, valves, fittings and tubing may need to be changed out as sanitary waste.

Compressed air and breathing air demands for the TFM\&C will use existing capabilities in 233-H and 234-H.

\section{A6.11 Building HVAC}

The TFM\&C building heating, ventilation and air conditioning systems provide climatic and humidity control inside the building. Building air flow is from regions of no radionuclide contamination (offices and change rooms) to low contamination (glovebox-contained tritium processing rooms). The required building air flow depends on free building volume outside of the gloveboxes and other confinement systems. During normal operation, HVAC exhaust duct flow is measured using flow rate sensors such as Pitot tubes; they are also equipped with pressure drop 
indicators. Building 233-H HVAC upgrade to support TFM\&C facilities will consist of two 90ton, 15,000-cfm, air cooled air conditioning units, associated duct work, tornado damper and control system. Building 234-H HVAC will be upgraded with a new 15-ton air conditioning unit.

Wastes generated by the HVAC include duct work, heating/cooling coils, fans, motors, dampers, gaskets and other maintenance parts, gauges, sensors and filters.

\section{A6.12 Process Heating/Cooling}

Process heating is usually provided electrically (e.g., stripper catalyst, zeolite beds) or directly through steam. It may also be done indirectly though a gas or liquid heat transfer medium (e.g. nitrogen).

Process cooling may include cooling of gas leaving the stripper catalyst bed and glovebox atmosphere gas. Hydride storage beds and the TCAP system also require cooling of the nitrogen gas heat transfer medium. Process cooling may be achieved directly using chilled water or liquid nitrogen/helium or indirectly using a gas or liquid heat transfer medium to remove and reject waste heat to the environment. Chilled water may be cooled using a cooling tower.

Process and building chilled water is usually recirculated and reused. To ensure efficient operation, the water chemistry must be properly maintained and corrosion products removed. Deionized and filtered water may have to be used for the cooling tower make-up.

Potential process heating/cooling waste streams have been previously cited under the Electrical System, Steam and Process and Building Chilled Water. Potentially hazardous wastes from the secondary cooling facilities are addressed in Appendix B under Cooling System and Maintenance Wastes.

\section{A6.13 Control Room/Integrated Control System}

The TFM\&C facilities will utilize the existing 233-H Control Room. The Control Room will provide for integrated operational control and monitoring of the TFM\&C production systems, and associated support and safety systems. A central computer may be used with supervisory capability over local computers and the capability to independently monitor and control critical safety functions of each processing system. The central computer system will also monitor facility support systems. Control and monitoring capabilities may include:

- Operation, maintenance and engineering interfaces

- Data acquisition

- Alarm management

- Data archiving and retrieval

- Real-time controls, hardware-based simulation

- Data distribution

- Self checking and diagnostics

Monitoring and control functions may also be available from local control stations located close to specified systems and sub-systems (distributed control systems or DCS's). These shall be used during system checkout, start-up, operation, shutdown, maintenance and other modes consistent with approved facility operating procedures. 
Operation status boards, shift roundsheets, procedures and QA records may be stored in the Control Room. It may also provide for personnel monitoring and controlling access to and from restricted radiological areas. Operator training, including use of simulators, is assumed to be conducted in the existing SRS central training facility in Building 766-H.

The Control Room will generate paper and other sanitary solid waste. Waste documents of a sensitive nature would need to be shredded or sent to classified scrap.

\section{A6.14 Offices and Change Rooms}

Existing offices in 249-H and 234-H will house the incremental TFM\&C administrative, managerial, operational, technical support, and clerical staff. Similarly, existing lunch rooms, rest rooms, bioassay stations, change rooms, data processing, and records filing room will be used. It is anticipated that these offices will not house any more personnel than today. Offices in 232-H may continue to house TFM\&C personnel.

Annual sanitary liquid waste generated by TFM\&C personnel is estimated to be $4,900 \mathrm{~m}^{3}$. Annual TFM\&C solid sanitary waste from all offices clean areas is estimated to be $58,000 \mathrm{~kg} / \mathrm{yr}$, based on a generation rate of $5 \mathrm{lbs} /$ per person/per day. Assuming a bulk density of $0.25 \mathrm{~kg} / \mathrm{m}^{3}$, waste volume is about $230 \mathrm{~m}^{3}$.

\section{A6.15 Safeguards and Security (S\&S)}

The existing 233-H and 234-H buildings are protected by a number of safeguards and security measures. Successful entry to the facility may require passing through an explosive detection system, a metal detector system, a proximity card system, and guard stations. Some rooms are also controlled by cipher and combination locks. The TFM\&C safeguards and security measures are assumed to be part of the existing Tritium Facilities infrastructure.

The S \& S systems undergo periodic maintenance. Instrument parts are replaced as needed.

\section{A6.16 Emergency Services}

To address emergency situations or off-normal events that may arise, the 233-H/234-H/249-H buildings are wired to communicate with the site Emergency Operations Office. Emergency lighting is provided throughout the facility to aid in facility evacuation in case of loss of lighting. This is particularly important since the $233-\mathrm{H}$ facilities are located underground. Emergency medical and spill clean-up kits are also strategically positioned throughout the facility.

Waste may be generated from emergency medical treatment or clean-up of spills.

\section{A6.17 Communication Services}

To address emergency situations that may arise, the $233-\mathrm{H} / 249-\mathrm{H} / 234-\mathrm{H}$ buildings are wired to communicate with the site Emergency Operations Office. Public Announcement systems are located through out these buildings. Offices and control rooms are wired for telephones and computer networking.

\section{A6.18 Maintenance Facilities}

Existing maintenance facilities provide adequate shop and service areas to support TFM\&C facility operations. They also provide warehousing and materials handling for consumables and 
spare parts. Process equipment and piping manifolds may be fabricated, welded, prepared, or painted. Welded piping is $x$-rayed to check for weld integrity.

Wastes generated in the Maintenance Facilities include metal piping, fittings, equipment parts, failed equipment, paint waste, and photographic waste.

\section{A6.19 Balance of Plant Waste Streams}

Most of the waste generated by the balance of Plant facilities will be non-hazardous and nonradioactive. Several of the waste stream possess potential for being hazardous, radioactive or mixed. The follow waste streams associated with the balance-of-plant facilities are discussed in Appendix B:

Job Control Waste (H-3)

Non-hazardous Solvent

Job Control Waste (Mixed Low-Level Waste)

Tritiated Water and Aqueous Solutions

Non-hazardous Tritiated Oil

Mixed and Hazardous Waste Oil/Solvent 


\section{APPENDIX B}

\section{Tritium Facility Modernization \& Consolidation Process Waste Streams}

This appendix will identify and address hazardous, low-level, and mixed low-level waste streams (both solid and liquid waste) associated with TFM\&C Project tritium processing, laboratory and metallurgical activities. The waste streams are identified based on the conceptual TFM\&C tritium purification processes and anticipated operations described in Appendix A. Current SRS operating practice requires individual waste characterization plans to be developed for each low-level and mixed low-level waste stream. These waste characterization plans must be approved before waste may be shipped to the Solid Waste Management Division.

Each waste stream description contains the following information:

Type: Identifies a solid waste stream as either hazardous waste, low-level radioactive waste (LLRW), or mixed low-level waste (MLLW). Radioactive liquid waste streams are also identified. No high-level or transuranic (TRU) waste is expected to be generated in tritium purification.

Definitions of low-level radioactive waste and hazardous waste are given below. Mixed waste is waste that is both radioactive and hazardous. Thus one may have mixed lowlevel waste, mixed high-level waste and mixed TRU waste.

Low level radioactive waste (LLRW) is defined by the Low-level Radioactive Waste Policy Amendments Act as radioactive waste that is not:

- High-level radioactive waste

- Spent nuclear fuel

- Byproduct material as defined in section 11E(2) of the Atomic Energy Act (uranium or thorium mill tailings)

NRC classifies LLRW based on the radionuclide content of the waste (10CFR61.55). $L L R W$ is classified as either $A, B$ or $C$ based on the long-and short-lived radioactive materials in the waste.

A hazardous waste is a solid waste that is not excluded from regulation and either:

- Listed as hazardous under CFR261.31-33

Nonspecific source hazardous materials include spent solvents, electroplating wastes, metal heat-treating waste, chlorinated aliphatic manufacturing residues and waste from the production or manufacturing of chlorophenolics. Specific source wastes include:

- Inorganic chemicals (waste water sludges, process residue, wastewaters)

- Secondary lead (emission control dust/sludge, waste leaching solution)

- Ink formulation (wastewater, solvent washes and sludges, wastewater treatment sludges) 
- Wood preservation (wastewater treatment sludges)

- Inorganic pigments (wastewater treatment sludges, process residues)

- Organic chemicals (still bottoms, spent catalysts, process residue)

- Pesticides (wastewater treatment sludges, filter solids, still bottoms, byproduct salts, wastewaters)

There are 318 commercial products listed as hazardous: 216 hazardous (U-list) and 102 acutely hazardous (P-list).

- Mixed with a listed hazardous waste

- Exhibits any of the four characteristics of ignitability (D001), corrosivity (D002), reactivity (D003) or EPA toxicity (D004-D014).

- Derived from the Storage, Treatment or Disposal of a hazardous waste, including:

- Sludges

- Treatment residue

- Ash

- Air emission control sludge/dust

- Leachate

A solid waste is any discarded material, in solid, liquid or gas form, not excluded by 40CFR261.4(a) or in the variance granted under 40CFR260.30-31. Discarded materials include materials that are abandoned, considered inherently waste-like or recycled. The following are excluded under 40CFR261.4(a) and are not considered solid wastes:

- Domestic sewage

- Waste discharged via public sewer to a publicly-owned treatment works

- Point source discharges subject to NPDES

- Irrigation return flows

- Waste subject to the Atomic Energy Act of 1954

- Wastes from in situ mining (when not removed from the ground)

- Unless accumulated speculatively,

- reclaimed pulping liquors that are re-used

- spent sulfuric acid used to produce virgin sulfuric acid

Description: Gives the waste stream physical matrix, EPA hazardous waste codes of RCRA components that may be present, source of radioactive contamination, radioactive isotopes and/or activity levels present.

Generation: Describes the process or activity that generates the waste stream.

Handling and Packaging: Describes the current or recommended handling techniques and packaging practices for the waste stream to meet applicable Waste Management Facility Waste Acceptance Criteria (WAC).

Annual Quantities: Gives estimated annual generation rates in mass and volume. Quantities are based on the experience of DOE facilities with similar operations or using similar components, anticipated levels of production activities and/or engineering judgment. For reference, SRS Tritium Facilities actual waste shipped in FY96 and forecasted FY97-98 waste shipments (exclusive of Non-Nuclear Reconfiguration Project waste) are presented in Table B1. 
Waste Minimization: Lists recommended methods for reducing or eliminating the waste stream. For potential mixed waste, lists recommendations for eliminating the hazardous component.

Treatment Options: Lists possible treatment technologies for LLRW or MLLW. Descriptions of the listed treatment technologies are given in Appendix C. It is assumed that hazardous waste which cannot be incinerated in the Consolidated Incineration Facility (CIF) will be packaged for treatment and/or disposal at a DOE-approved DOE or commercial waste management facility. One notable exception is corrosive-only hazardous waste that must be treated by the waste generator before disposal.

Comments: Provides additional information, which does not fit in the other categories, to help understand the nature of the waste stream or its treatment.

Thirteen different waste streams have been identified in this Appendix. Several waste streams have been subdivided to provide for expanded discussions of the waste stream components. DOE Order 6430.1 states that radioactive mixed waste shall be avoided where practical and that mixed waste that cannot be avoided shall be identified and considered in the facility design at the earliest possible time. In this Appendix, the identified mixed waste streams can all potentially be avoided. Thus the projected waste generation quantities for these mixed waste streams are either minimal or may be reduced further in practice. 
Tritium Facilities Modernization \& Consolidation Project

WSRC-TR-97-00368,Rev.0

Process Waste Assessment

November 14,1997

Table B1. SRS Tritium Facilities FY98 Waste Forecast ${ }^{\star}$

(Volumes in $\mathrm{ft}^{3}$ )

\begin{tabular}{|c|c|c|c|c|c|}
\hline & $\begin{array}{c}\text { Waste } \\
\text { Management } \\
\text { Facility }\end{array}$ & $\begin{array}{l}\text { FY96 } \\
\text { (Actual) }\end{array}$ & $\begin{array}{l}\text { FY97 } \\
\text { (Actual) }\end{array}$ & FY98 & Comments \\
\hline \multicolumn{6}{|l|}{ EXTRACTION } \\
\hline Job Control Waste & CIF & 0 & 180 & 180 & \\
\hline Mixed Low -Level & Interim Storage & $\overline{15}$ & 15 & 7 & $\begin{array}{c}\text { Freon rags from } \\
\text { U-bed } \\
\text { preparation }\end{array}$ \\
\hline \multicolumn{6}{|l|}{ H-3 PURIFICATION } \\
\hline $\begin{array}{l}\text { Job Control } \\
(232-\mathrm{H}, 233-\mathrm{H}, 234-\mathrm{H}, \\
238-\mathrm{H})\end{array}$ & LAW Vaults & 14,500 & 10,500 & 10,500 & \\
\hline $\begin{array}{l}\text { Job Control } \\
(232-\mathrm{H}, 233-\mathrm{H}, 234-\mathrm{H}, \\
238-\mathrm{H})\end{array}$ & CIF & 6,500 & 10,500 & 10,500 & \\
\hline $\begin{array}{l}\text { Nonhazardous Equipment } \\
(232-\mathrm{H}, 233-\mathrm{H}, 234-\mathrm{H})\end{array}$ & ILTV Bulk Cell & 1,980 & 2,835 & 2,475 & $\begin{array}{l}\text { Includes U beds, } \\
\text { Mg beds, and Z } \\
\text { beds }\end{array}$ \\
\hline $\begin{array}{l}\text { Chiller Oil } \\
\text { (232-H, 233-H) }\end{array}$ & CIF & $\overline{0}$ & 162 & 0 & $\begin{array}{l}\text { Halogens too } \\
\text { high for Power } \\
\text { House }\end{array}$ \\
\hline $\begin{array}{l}\text { Tritiated Waste Oil } \\
\text { (232-H, 233-H, 234-H) }\end{array}$ & LAW Vaults & 0 & 88 & 88 & $\begin{array}{l}\text { Includes stored } \\
\text { and new waste } \\
\text { oil }\end{array}$ \\
\hline $\begin{array}{l}\text { Hazardous Solvent } \\
\text { (249-H) }\end{array}$ & Interim Storage & 7 & 7 & 7 & $\begin{array}{l}\text { CFC-11 solvent } \\
\text { \& oil }\end{array}$ \\
\hline $\begin{array}{l}\text { Mixed Waste Equipment } \\
(232-\mathrm{H}, 233-\mathrm{H}, 234-\mathrm{H})\end{array}$ & Interim Storage & 90 & 100 & 100 & $\begin{array}{l}\mathrm{Hg} \text { and } \mathrm{Pb} \\
\text { contaminated }\end{array}$ \\
\hline Mixed Oil (232-H, 234-H) & Interim Storage & 45 & 77 & 22 & $\begin{array}{l}\text { Hg } \\
\text { contaminated }\end{array}$ \\
\hline $\begin{array}{l}\text { Mixed Job Control (233- } \\
\text { H) }\end{array}$ & Interim Storage & 0 & $\mathbf{0}$ & 5 & Methanol rags \\
\hline Mixed Freon Rags (234-H) & Interim Storage & $\mathbf{0}$ & 32 & 0 & \\
\hline
\end{tabular}

*This table excludes waste forecast from the Non-Nuclear Reconfiguration Project.

Note: A B-25 container is nominally $90 \mathrm{ft}^{3}$ and a 21 " cubic cardboard box has a volume of 5.4 $f^{3}$ 


\section{B1. Job Control Waste (H-3)}

\section{Type: Low-Level Radioactive Waste}

Description: Job Control Waste (JCW) is the predominant low-level waste stream by volume. JCW normally contains personal protective equipment (PPE) such as shoe covers, gloves, plastic suits, and air hoses. Other JCW includes kraft paper, sheet plastic, rags, absorbent wipes and tape used for radiological control and small equipment parts such as o-rings, gaskets, pipe fittings, broken glass test tubes and beakers. Metallurgical lab housekeeping wastes are generally disposed as job control waste; exceptions include machine lubricants and cutting fluids.

Generation: TFM\&C Job Control Waste (H-3) is generated during production, maintenance, decontamination or housekeeping activities in the tritium processing areas and the R\&D tritium test manifold in 233-H and the met labs in 234-H. Job Control Waste (H-3) is collected from all tritium-contaminated processing areas and buildings. Tritium should be the only significant radioactive contaminant. It exists mostly as removable surface contamination. Tritium diffusion into cellulosic and plastic materials is usually negligible, due to the absence of a strong driving force (high temperature or tritium partial pressure). Once an item is contaminated, tritium may diffuse throughout the material. However, the total amount of tritium in the material will not increase as a result of diffusion.

Handling and Packaging: Depending upon tritium content, this waste stream is segregated into incinerable, compactible or non-compactible fractions based on waste form and the contamination level of the location where the waste was generated. Plastic and cellulosic items and most small metal items will be incinerated in the CIF. Incinerable or compactible waste, after bagging, is monitored for detectable off-gassing tritium (greater than $4 \mathrm{E}-5 \mathrm{mCi} / \mathrm{cc}$ ). To ensure that this criterion is maintained, waste from areas with tritium contamination greater than $3.7 \mathrm{E}+6 \mathrm{dpm}$ $\mathrm{H}-3 / 100 \mathrm{~cm}^{2}$ is segregated. Incinerable or compactable waste is packaged in 21 " $\times 21$ " $\times 21$ " cardboard radioactive waste boxes that are in good condition, and lined with a plastic bag. When a bag is full, it is monitored for off-gassing tritium and surveyed for external surface contamination before shipment. Non-incinerable waste is placed in yellow or yellow-striped clear plastic radioactive waste bags. Closed waste packages are surveyed for off-gassing tritium and for external contamination before being transferred to a B-25 box. Partially filled B-25 boxes are locked or stored inside a locked fence. Once a B-25 box is filled, it is closed and manifested for transportation to Solid Waste management. Waste will then be directed to the CIF for incineration, to an off-site vendor for compaction, or to E-Area Vaults (EAV) Low Activity Waste (LAW) Vaults for disposal.

Annual Quantities:

\begin{tabular}{|r|r|r|r|r|}
\hline & & Waste Destination & & \\
\hline $900 \mathrm{ft}^{3}$ & $8,370 \mathrm{lb}$ & CIF & $25.2 \mathrm{~m}^{3}$ & $3,800 \mathrm{~kg}$ \\
\hline $150 \mathrm{ft}^{3}$ & $1,395 \mathrm{lb}$ & Compaction/LAW Vaults & $4.2 \mathrm{~m}^{3}$ & $634 \mathrm{~kg}$ \\
\hline $150 \mathrm{ft}^{3}$ & $1,395 \mathrm{lb}$ & Direct to LAW Vaults & $4.2 \mathrm{~m}^{3}$ & $634 \mathrm{~kg}$ \\
\hline
\end{tabular}

(a) Assume baseline of $21,000 \mathrm{ft}^{3}$ per year for 14 extractions and 233-H per Table B1. 
(b) Per current practice, assume 2/3 for combined CLWR-TEF and TFM $\& C=14,000 \mathrm{ft}^{3}$.

(c) Assume 14 extractions/year in CLWR-TEF $\Rightarrow 14,000 \mathrm{ft}^{3}$.

(d) Assume x 1/2 for improved waste minimization practices in gloveboxes $=7,000 \mathrm{ft}^{3}$.

(e) Assume $\times 1 / 2$ for CLWR-TEF and TFM\&C Processing areas $\Rightarrow 3,500 \mathrm{ft}^{3}$.

(f) Assume $1 / 3$ for TFM\&C facilities $(233-\mathrm{H}$ and $234-\mathrm{H}) \Rightarrow 1,200 \mathrm{ft}^{3}$

(g) Assume $75 \%$ to CIF, $12.5 \%$ to Compaction/LAW Vaults, $12.5 \%$ directly to LAW Vaults, or $900 \mathrm{ft}^{3}$ to CIF, $150 \mathrm{ft}^{3}$ to Compaction/LAW Vaults, $150 \mathrm{ft}^{3}$ to LAW Vaults.

(h) Administrative limit of $50 \mathrm{lb}$. in 21 " $\times 21 " \times 21$ " box or $5.4 \mathrm{ft}^{3} \Rightarrow 9.3 \mathrm{lb} / \mathrm{ft}^{3}$ bulk density before compaction.

(i) Assume compaction gives $4 \mathrm{x}$ volume reduction $\Rightarrow 37.5 \mathrm{ft}^{3}$ compacted waste volume.

\section{Waste Minimization:}

(a) Process design changes can eliminate the potential for spills or pooling of cleaning solutions. Glovebox operation also eliminates the need for plastic suits, air hoses, etc., during maintenance and line breaks.

(b) Product substitution. For example, SRS evaluated the use of polyester wipes as a substitute for a product previously used in a variety of cleaning/decon situations. The polyester wipes were found to reduce the volume of generated wastes without diminishing performance and have been adopted for site-wide use.

\section{Treatment Options:}

(a) Incineration at CIF, followed by cement stabilization of ash/residue. Disposal of stabilized ash in the E-Area Vaults if passes TCLP; storage as mixed waste for further treatment if waste fails TCLP. (Note: SRTC does a modified TCLP using much less material (1-20 grams) than the 100 grams specified in the TCLP protocol. This is done to minimize waste generation.)

(b) Compaction for disposal in the EAV LAW Vaults. Super-compaction would provide even greater volume reduction.

(c) Direct disposal in the EAV LAW Vaults.

Comments:

(a) In a 1992 PWA, absorbent wipes made up $1 \%$ of a total waste of $25,457 \mathrm{ft}^{3}\left(721 \mathrm{~m}^{3}\right)$ at the SRS tritium processing facility (Ref: WSRC, “1992 Process Waste Assessment, Tritium Facility Low-level Waste," NMP-STE-93138, 8/13/93). Waste stream 
characteristics were estimated on the basis of purchasing records, observation of sample waste-handling activities, and interviews with operations personnel.

(b) It may not be necessary to routinely assay this waste stream for gamma contamination; only tritium weak beta contamination is expected to be present.

(c) Compaction of tritium contaminated job control waste should be conducted carefully. There is a potential for off-gassed tritium trapped in the plastic bags to be released during compaction.

(d) The estimated waste volumes are slightly higher than those estimated by Rabun (Ref. 16). The authors believe the estimate presented here is reasonable for the following reasons. The forecast waste volume equates to approximately twelve B-25 containers a year. Per current practice, the met labs generate one to two 21 " cardboard boxes of rad waste total each week. Assuming met lab operations to produce two 21" cardboard boxes of waste per week at full capability, one B-25 container of rad waste is generated every 4 months, or three for the year. Tritium processing activities would then be estimated to generate the remaining nine B-25's.

(e) It has been pointed by a reviewer of the PWA (Alexander) that waste generation does not necessarily correlate to production rate. This is quite plausible, as one does not engage in waste generating activities such as maintenance, housekeeping or decontamination unless there is a "lull" in production activities. Thus it would not be surprising to experience high waste generation in years with low production activities. However, the need for equipment maintenance and replacement of parts, certain process generated equipment and rad contamination level in waste are undeniably related to levels of production. Thus, for lack of a better method or assumption, waste generation rate estimated in this PWA will be scaled to production rates. 


\section{B1a. Non-hazardous Solvents}

Type: Low-level Radioactive Waste.

Description: Residues of non-hazardous solutions used for decontamination, cleaning, or degreasing during equipment maintenance or repair. The solvents may become contaminated with tritium during the cleaning process. Several cleaning agents may be found in the chemicals list under Waste B8.

Generation: Routine maintenance, cleaning, degreasing, and decontamination activities.

Handling and Packaging: Pour onto rags and combine with Waste Stream B1.

Annual Quantities: Included in Waste Stream B1.

Waste Minimization:

Change to mechanical/physical stripping/cleaning devices to avoid solvent use.

Treatment Options: See Waste Stream B1.

\section{Comments:}

None. 


\section{B2. Job Control Waste (Mired Low-Level Waste)}

Type: Mixed Low-level Radioactive, Hazardous

Description: Job Control Waste normally contains personal protective equipment (PPE) such as shoe covers, gloves, plastic suits, and air hoses. Other JCW includes kraft paper, sheet plastic, rags, absorbent wipes and tape used for radiological control and small equipment parts such as orings, gaskets, pipe fittings, broken glass test tubes and beakers. Metallurgical lab housekeeping wastes are generally disposed as job control waste; exceptions include machine lubricants and cutting fluids. Methanol and Freon and other cleaning agents are potential hazardous contaminants. Many instrument computer boards may also contain RCRA metals.

Generation: See Waste Stream B1.

Handling and Packaging: See Waste Stream B1.

Annual Quantities:

\begin{tabular}{|r|r|c|r|r|}
\hline & & Waste Destination & & \\
\hline $90 \mathrm{ft}^{3}$ & $837 \mathrm{lb}$ & Interim Storage/Off-site & $2.5 \mathrm{~m}^{3}$ & $380 \mathrm{~kg}$ \\
\hline $90 \mathrm{ft}^{3}$ & $837 \mathrm{lb}$ & $\mathrm{CIF}$ & $2.5 \mathrm{~m}^{3}$ & $380 \mathrm{~kg}$ \\
\hline
\end{tabular}

(a) Assume one B-25 container to CIF per year $\Rightarrow 90 \mathrm{ft}^{3}$.

(b) Assume one B-25 container to Interim Storage/Off-site per year $\Rightarrow 90 \mathrm{ft}^{3}$.

(c) Administrative limit of $50 \mathrm{lb}$. in 21 "x21" $\times 21$ " box or $5.4 \mathrm{ft}^{3} \Rightarrow 9.3 \mathrm{lb} / \mathrm{ft}^{3}$ bulk density before compaction.

Waste Minimization: See Waste Stream B1.

Treatment Options:

(a) Incineration at CIF for solvent rags, followed by cement stabilization of ash/residue.

(b) Thermal desorption followed by storage or disposal.

\section{Comments:}

(a) If listed material is incinerated, residue must be stabilized and disposed in a RCRA Subtitle $\mathbf{C}$ facility.

(b) While thermal desorption of volatile organics may convert a mixed waste to a low-level waste, if the off-gases are adsorbed on activated carbon, this becomes a secondary waste stream. 


\section{B2a. Mired Waste Solvent Rags}

\section{Type: Mixed Low-level Waste.}

Description: Rags or paper products (such as Kim-Wipes) that have been impregnated with solutions used for decontamination, cleaning, degreasing, spill clean-up and various maintenance activities. The solutions may contain hazardous components such as Freon or methanol and/or may also become contaminated with radioactive or hazardous components wiped from the object being cleaned.

Generation: Routine maintenance, cleaning, degreasing, and decontamination activities.

Handling and Packaging: Handled and packaged similarly to job control waste. Waste items are placed in plastic bags and 21 " $\times 21$ " $\times 21$ " cardboard boxes. The outside of the plastic bags are smeared for contamination and sniffed for detectable tritium off-gassing of $4 \mathrm{E}-5 \mathrm{~m} \mathrm{Ci} / \mathrm{cc}$.

Annual Quantities: Minimal.

Waste Minimization:

(a) Product substitution, to eliminate RCRA hazardous solvents (e.g., Freon, methanol).

(b) Change to mechanical/physical stripping/cleaning devices to avoid solvent use.

\section{Treatment Options:}

(a) Thermal desorption followed by compaction for storage and/or disposal.

(b) Incineration at CIF, followed by stabilization or vitrification of ash.

\section{Comments:}

(a) Current environmental regulations make it advantageous to avoid the generation of mixed waste. Use of non-hazardous cleaning agents is advisable when the solvent rags will come in contact with radioactive materials. Commercially available rags impregnated with a decontamination solution (brand name Maslin Wipes) have been tested by Sandia National Laboratories - New Mexico for hazardous components and have been found to be nonhazardous.

(b) While thermal desorption of volatile organics may convert a mixed waste to a low-level waste, if the off-gas is absorbed on activated carbon, the spent carbon bed becomes a secondary waste stream. 


\section{B3. Non-hazardous Process Equipment (H-3)}

\section{Type: Low-level Radioactive Waste}

Description: This waste stream consists of discarded process equipment or parts which provided primary tritium containment. It includes equipment such as vessels, tanks, pressure gauges, valves, fittings and secondary containers. Minor maintenance parts (e.g., small gaskets, bolts) are managed as Job Control Waste. This waste stream does not include tritium reservoir and high-pressure tritium processing tanks. All process equipment is non-incinerable and noncompactable due to physical form and potential tritium off-gassing. Component tritium content may be assigned based on experimentally determined correlation (e.g., $0.05 \mathrm{Ci}$ of tritium per square foot of tritium-exposed surface.).

Generation: Non-hazardous Process Equipment (H-3) waste is generated by preventive and corrective maintenance of the post-extraction tritium processing systems, or by replacement of catalyst beds or containment devices.

Handling and Packaging: Tritium is removed from waste process equipment by flushing with purge gas or heating. Following removal from the process system and glovebox, waste equipment is stored in an engineered hood to control off-gassing tritium within a monitored ventilation system. Management will review off-gassing rate and facility conditions to determine when to dispose of process equipment. Following a period of off-gassing, the plastic-wrapped equipment will be placed into pre-approved containers (such as B-12 containers) for transport to the E-Area Vaults.

\section{Annual Quantities:}

\begin{tabular}{|r|r|c|r|r|}
\hline & & Waste Destination & & \\
\hline $45 \mathrm{ft}^{3}$ & $3,750 \mathrm{lb}$. & LAW Vaults & $1.3 \mathrm{~m}^{3}$ & $1,705 \mathrm{~kg}$ \\
\hline $45 \mathrm{ft}^{3}$ & $3,750 \mathrm{lb}$. & ILTV Bulk Cell & $1.3 \mathrm{~m}^{3}$ & $1,705 \mathrm{~kg}$ \\
\hline
\end{tabular}

(a) Assume one B-12 containers per year to LAW Vaults $\Rightarrow 45 \mathrm{ft}^{3}$.

(b) Assume one B-12 containers per year to ILTV Bulk Cell $\Rightarrow 45 \mathrm{ft}^{3}$

(c) Assume 75\% void space, 50 vol \% aluminum (2.7 SpG), 50 vol \% stainless steel (8.0 $\mathrm{SpG}) \Rightarrow 45 \times 0.25 \times 62.3 \times(0.5 \times 2.7+0.5 \times 8) \sim 3,750 \mathrm{lb}$.

\section{Waste Minimization:}

(a) Use preventive maintenance to extend process equipment life.

(b) Decontaminate equipment and/or recycle metal.

(c) Use volume reduction techniques (cutting, compaction, etc.) to minimize final waste volume. 
Tritium Facilities Modernization \& Consolidation Project

Process Waste Assessment
WSRC-TR-97-00368,Rev.0

November 14,1997

\section{Treatment Options:}

(a) Thermal desorption to remove as much tritium as practical.

(b) Off-gassing in an engineered air hood to protect handling personnel.

(c) Depending on tritium content, waste equipment will be disposed of in either the LAW Vaults or the ILTV Bulk Cell.

Comments: None. 


\section{B4. Magnesium/Uranium Beds}

\section{Type: Low-level Radioactive Waste.}

Description: Uranium beds currently in use at SRS are about four feet long and two feet in diameter. The bed material is initially turnings of depleted uranium, but as the bed is used the material is oxidized to uranium oxide. Similarly, magnesium bed material is initially magnesium metal filings that oxidize to magnesium oxide as the bed is used. Both types of spent beds are contaminated with tritium. Spent depleted uranium beds also contain isotopes of uranium that must be manifested.

Generation: In the Z-bed Recovery process, magnesium or uranium is consumed while cracking tritiated water to recover tritium adsorbed as tritiated water on zeolite beds. The zeolite beds are regenerated for reuse by heating and circulating a carrier gas, which carries desorbed water or hydrogen oxides to heated magnesium or uranium beds. The hydrogen oxides react with magnesium or uranium to form a magnesium or uranium oxide and release elemental hydrogen isotopes. This mixture of hydrogen isotopes again undergoes isotopic separation. The baseline technology for TFM\&C Z-Bed Recovery uses magnesium beds. Mg beds are preferred over U beds for waste minimization; there is much more job control waste generated in preparing the $U$ beds.

\section{Handling and Packaging:}

The outer bed surface is decontaminated and the beds are bagged for disposal in a B-12 container for shipment to the EAV Intermediate Level Tritium Vaults Bulk Cell.

Annual Quantities:

\begin{tabular}{|r|r|c|r|r|}
\hline & & Waste Destination & & \\
\hline $50 \mathrm{ft}^{3}$ & $2,200 \mathrm{lb}$ & U Beds to ILTV Bulk Cell & $1.4 \mathrm{~m}^{3}$ & $1,000 \mathrm{~kg}$ \\
\hline $100 \mathrm{ft}^{3}$ & $1,880 \mathrm{lb}$. & Mg Beds to ILTV Bulk Cell & $2.8 \mathrm{~m}^{3}$ & $855 \mathrm{~kg}$ \\
\hline
\end{tabular}

(a) Assume two beds in TFM\&C process (one set of two beds in parallel), and replacing 1 bed every quarter or 4 beds per year.

(b) Assume each $U$ bed is 2 feet $0 . D . \times 4$ feet long $\Rightarrow 12.6 \mathrm{ft}^{3}$.

(c) Assume 95\% void space, uranium $(\mathrm{SpG}=19) \Rightarrow \sim 250 \mathrm{lb}$ each $\mathrm{U}$ bed.

(d) Assume 24" Schedule 10 steel pipe container $(63.4 \mathrm{lb} / \mathrm{ft}) \Rightarrow \sim 250 \mathrm{lb}$. Plus $50 \mathrm{lb}$ for ends gives $\sim 300 \mathrm{lb}$ for total container weight. Total $U$ bed weight $550 \mathrm{lb}$ each.

(e) Assume $\mathrm{Mg}$ beds are sized $2 \mathrm{x}$ for same duty $\Rightarrow 25 \mathrm{ft}^{3} / \mathrm{Mg}$ bed.

(f) Assume 95\% void space, magnesium ( $\mathrm{SpG}=1.7) \Rightarrow 130 \mathrm{lb}$ of $\mathrm{Mg}$ in each $\mathrm{Mg}$ bed. 
(g) Assume 24" Schedule 10 steel container weighs $\sim 340 \mathrm{lb}$. each $=>470 \mathrm{lb} /$ loaded $\mathrm{Mg}$ bed.

\section{Waste Minimization:}

(a) Investigate alternative $z$-bed regeneration technologies using palladium membrane reactor, regenerable iron oxide beds or solid oxide electrolysis.

\section{Treatment Options:}

Waste uranium or magnesium beds are sealed, self-contained units that can be packaged in gloveboxes under a nitrogen atmosphere for disposal. However, the uranium or magnesium must be completely oxidized to destroy its ignitability characteristic to meet disposal Waste Acceptance Criteria.

Comments:

(a). SRS Tritium Facilities operating personnel prefer magnesium beds over uranium beds and are in the process of replacing the remaining uranium beds in $233-\mathrm{H}$ to magnesium beds. While uranium and uranium oxide are not hazardous listed materials under RCRA, the depleted beds are a fire hazard because the finely divided powder that forms can ignite spontaneously in air. Magnesium beds are somewhat less reactive, but similar precautions should be used. 


\section{B5. Hydride/Getter/Catalyst/Zeolite Beds}

Type: Low-level Radioactive Waste.

Description: Hydride storage beds (e.g., LANA beds) currently in use at SRS are 4" in diameter and 3 feet long per unit. They have an inner container made of 3" Schedule 40 stainless steel and an outer container made of 4" Schedule 10 stainless steel. Each unit has about 45 pounds of stainless steel in the container and 15 pounds of metal hydride material in the bed. LANA metal hydride storage bed packing material contains nickel, which is under heavy scrutiny as an environmental hazard and is on some state lists as a hazardous material. Waste hydride beds will contain residual tritium.

Getters are alloy pellets containing $\mathrm{Zr} / \mathrm{Fe} / \mathrm{Mn}$ (St909) for cracking water and oxygen removal, or $\mathrm{Zr} 2 \mathrm{Fe}$ (St198) for gettering hydrogen. Waste getter beds will be contaminated with tritium.

Platinum/Alumina catalyst beds consist of pellets of finely dispersed platinum metal on an alumina substrate. Alumina is aluminum oxide, $\mathbf{A l}_{2} \mathrm{O}_{3}$, which is non-combustible and non-toxic. Catalytic purifier is a palladium on alumina catalyst. Waste catalyst beds will be contaminated with tritium.

Zeolite is either a naturally hydrated silicate of aluminum and either sodium or calcium or both, of the type $\mathrm{Na}_{2} \mathrm{O}^{\circ} \mathrm{Al}_{2} \mathrm{O}_{3} \mathrm{nH}_{2} \mathrm{O}$; or an artificial ion exchange resin. Artificial zeolites are made in a variety of forms, ranging from gelatinous to porous and sand-like, and are used as gas adsorbents, water softeners, drying agents, and catalysts. Molecular sieves are a group of adsorptive desiccants which belong to the zeolite family. The outstanding characteristic of these materials is their ability to undergo dehydration with little or no change in crystal structure. The dehydrated crystals are interlaced with regularly spaced channels of molecular dimensions that comprise almost $50 \%$ of the total volume of the crystals. The empty cavities in an activated molecular sieve have a strong tendency to recapture the water molecules that have been driven off. Waste zeolite beds are containerized molecular sieve beads or pellets contaminated with tritium.

Generation: LANA hydride beds currently in use for storing tritium have a tendency to trap the helium-3 decay product of tritium. It is assumed that helium buildup will eventually lead to hydride bed failure and need for replacement. The expected LANA hydride bed lifetime is about five years.

Getter beds are used in the process stripper system to detritiate nitrogen-evac gas, diffuser effluent gas and CLWR-TEF furnace flush gas. The St909 getter is depleted as it reacts with water and oxygen and must be replaced periodically. The St198 bed is regenerable. However, its gettering efficiency and hydrogen capacity decrease with use and it must be replaced as needed.

Stripper systems are used to recover tritium from glovebox nitrogen that is circulated back to the gloveboxs or purged to the stack. The Primary and Secondary stripper systems operate by pumping the gas over a heated Pt/Alumina catalyst bed (Engelhard Deoxo D) to oxidize the molecular hydrogen isotopic species to tritiated water. The resulting tritiated water, regular water, and HTO are then adsorbed by the molecular sieve in the zeolite beds. The molecular sieve can be 
regenerated and reused until a physical breakdown in the material necessitates its replacement. At that time the entire unit, consisting of the container and the molecular sieve, will be replaced.

Handling and Packaging: Tritium is removed from waste hydride/getter/catalyst/zeolite equipment by flushing with purge gas, heating, and/or isotopic exchange. Hydride, getter and catalyst beds need to be passivated and isolated. Following removal from process, process equipment may be stored in engineered air hoods or gloveboxes to control off-gassing tritium within a monitored ventilation system. Management will review off-gassing rate and facility conditions to determine when to dispose of process equipment. Following a period of off-gassing, spent beds are wrapped in plastic bags (heavy duty polyurethane) and placed into pre-approved containers (e.g., B-12 containers) for disposal in the E-Area Vaults.

Annual Quantities:

\begin{tabular}{|r|r|c|r|r|}
\hline & & Waste Destination & & \\
\hline $4.8 \mathrm{ft}^{3}$ & $120 \mathrm{lb}$ & $\begin{array}{c}\text { Hydride Beds to LAW } \\
\text { Vaults }\end{array}$ & $0.14 \mathrm{~m}^{3}$ & $55 \mathrm{~kg}$ \\
\hline $0.25 \mathrm{ft}^{3}$ & $105 \mathrm{lb}$ & Getter Beds to LAW Vaults & $0.007 \mathrm{~m}^{3}$ & $48 \mathrm{~kg}$ \\
\hline
\end{tabular}

(a) Assume two hydride beds per year after 5 years of operation; no 233-H hydride bed has been disposed as waste after 5 years of RTF operation.

(b) Assume each jacketed hydride bed is 12 in $0 . \mathrm{D} . \times 3$ feet long $=2.4 \mathrm{ft}^{3}$.

(c) Assume each bed is about $45 \mathrm{lb}$. container and $15 \mathrm{lb}$. metal hydride. Container weight check:

Inner container: 3 " Schedule 40 steel pipe $(7.6 \mathrm{lb} / \mathrm{ft}) \times 3 \mathrm{ft}=22.8 \mathrm{lb}$.

Outer container: 4" Schedule 10 steel pipe $(5.6 \mathrm{lb} / \mathrm{ft}) \times 3 \mathrm{ft}=16.8 \mathrm{lb}$.

(d) Assume two St909 getter beds per year.

(e) Assume each St909 getter bed is 3 in $0 . \mathrm{D} . \times 2$ feet long $\Rightarrow 0.1 \mathrm{ft}^{3}$.

(f) Assume each bed is about $20 \mathrm{lb}$ container and $22 \mathrm{lb}$. Getter. Container weight check:

Container: 3" Schedule 40 steel pipe (7.6 lb/ft) $\times 2 \mathrm{ft}=15.2 \mathrm{lb}$.

Allow $5 \mathrm{lb}$. for flanges and frit filters and fittings.

(g) Assume one St198 getter bed every two years.

(h) Assume each St198 getter bed is 3 in $0 . D . \times 2$ feet long $\Rightarrow 0.1 \mathrm{ft}^{3}$.

(i) Assume each bed is about $20 \mathrm{lb}$. container and $22 \mathrm{lb}$. Getter. Container weight check:

Container: 3" Schedule 40 steel pipe (7.6 lb./ft) $\times 2 \mathrm{ft}=15.2 \mathrm{lb}$.

Allow $5 \mathrm{lb}$. for flanges and frit filters and fittings. 
(j) Assume no routine waste catalyst and Z beds; they are expected to last the design life of the TFM\&C process of 40 years.

\section{Treatment Options:}

(a) For hydride and getter beds, use isotopic exchange following thermal/vacuum desorption.

(b) Hydride, getter and catalyst beds must be passivated with air or oxygen to eliminate potential for spontaneous combustion. The entire containerized units are packaged for disposal without removing the packing materials.

(c) Zeolite beds are thermally desorbed to Z-Bed Recovery. Isotopic swamping or exchange may be desirable to recover tritium prior to disposal.

Waste Minimization:

No waste minimization efforts have been identified.

\section{Comments:}

(a) The SRS Tritium Facilities currently has 10-15 hydride beds in use, with an estimated 2 to 3 beds requiring replacement each year. LANA hydride bed service life is expected to be 5 years or more.

(b) As they are cycled, metal hydrides become finely divided powders that are potentially pyrophoric.

(c) When metal hydrides are used for tritium capture and storage, it is uncertain whether the hydrides can reduce the tritium concentration in the waste gas to the 5 to 10 parts per million achieved during cryogenic distillation.

(d) In 233-H, type 3A zeolite is used in the Stripper System zeolite beds. Since zeolite 3A does not adsorb $\mathrm{CO}_{2}$, the $\mathrm{CO}_{2}$ generated by the oxidation of organics goes out with the purge gas and does not accumulate in the zeolite beds.

(e) At TSTA the same molecular sieve was used for 10 years (not continuous use). The material was then replaced, not because of failure, but to investigate hold-up tritium on the bed.

(f) St198 getter effective life of two years is a best-estimate at this time. 


\section{B6. Mired Waste Process Equipment}

\section{Type: Mixed Low-level Waste}

Description: One specific mixed waste process equipment identified so far is the palladiumsilver diffuser. Palladium-silver diffusers currently in use at SRS are about two feet long and one foot in diameter. Silver is a hazardous material with RCRA code D011. During use the diffusers will become contaminated with tritium.

Generation: Existing tritium processing at SRS uses palladium-silver alloy diffusers to separate hydrogen isotopes from $\mathrm{He}-3$ and $\mathrm{He}-4$ after target rods are melted in crucibles to release the trapped gases. A similar TFM\&C process system will need two diffusers. Experience at SRS is that the diffusers must be replace after two or three years of service.

Mixed Process Equipment waste is generated by preventative and corrective maintenance of the extraction and post-extraction tritium processing systems which contain $\mathrm{RCRA}$ metals $(\mathrm{Hg}, \mathrm{Cd}$, $\mathrm{Ag}, \mathrm{Pb}$, etc.) or weld, or by replacement of Pd-Ag Diffusers. Historical equipment such as tritium product containers may contain mercury contamination and require treatment as mixed waste.

Annual Quantities:

\begin{tabular}{|r|r|c|r|r|}
\hline & & Waste Destination & & \\
\hline $0.3 \mathrm{ft}^{3}$ & $50 \mathrm{lb}$. & $\begin{array}{c}\text { Pd-Ag Diffusers to Interim } \\
\text { Storage/Off-site }\end{array}$ & $0.01 \mathrm{~m}^{3}$ & $23 \mathrm{~kg}$ \\
\hline
\end{tabular}

(a) Assume one Pd-Ag diffuser every 5 years.

(b) Assume each diffuser is 12 in $0 . \mathrm{D} . \times 2$ feet long $\Rightarrow 1.6 \mathrm{ft}^{3}$.

(c) Assume, for shell container, 12" schedule 10 steel pipe $(24.2 \mathrm{lb} . / \mathrm{ft}) \Rightarrow 48.4 \mathrm{lb}$.

(d) Assume, for tubes, $75 \%$ void, steel $(\mathrm{SpG}=8)=>200 \mathrm{lb}$.

(e) Divide unit weight $(-250 \mathrm{lb}$.) and volume by 5 to obtain annual generation rates.

Handling and Packaging: Following removal from process and glovebox, waste equipment is stored in engineered air hoods to control off-gassing tritium within a monitored ventilation system. Management will review off-gassing rate and facility conditions to determine when to dispose of process equipment. Waste equipment pieces are wrapped in plastic bags (heavy duty polyurethane). Following a period of off-gassing, the plastic-wrapped equipment will be placed into pre-approved containers (B-12, B-25, 55 gallon drums, 5 gallon containers, etc.) for transport to the Mixed Waste Storage pads or buildings.

Waste Minimization:

(a) Remove dirt from the tritium extraction and processing lines to prolong diffuser lifetime. 
(b) Improve manufacturing methods or diffuser design to eliminate current diffuser brazing failures.

(c) Extend process equipment life by controlling process gas oxygen and water vapor limits.

(d) Extend process equipment life though preventive maintenance.

(e) Decontaminate equipment/recycle metal.

\section{Treatment Options:}

(a) Macro-encapsulation prior to packaging for storage and/or disposal.

(b) Thermal de-sorption to remove as much tritium as practical.

\section{Comments;}

(a) Failure of diffusers has been attributed to manufacturer brazing problems or to dirt in the current tritium processing lines. In a clean facility diffusers should last longer, but there is no experience to prove that. The hydrogen passing through the palladium will eventually cause embrittlement and swelling and will result in change-out even if current problems with brazing are resolved. Oxygen and water vapor can attack Pd-Ag diffusers, causing intergranular failure

(b) Chromium in stainless steel, Inconel or zircaloy is assumed to pass the TCLP tests, due to the high corrosion resistance of these materials.

(c) TCLP testing of Pd-Ag diffusers may allow this waste to be managed as low-level waste. 


\section{B6a. Teledyne Orygen Sensor Micro-Fuel Cells}

\section{Type: Mixed Low-level Waste, Hazardous Waste.}

Description: Micro-fuel cells used in the Teledyne oxygen sensors are sealed in a cell which contains lead (D008). The sensors are used in both clean and tritium-contaminated environments.

Generation: Spent fuel cells from Teledyne oxygen sensors used in tritiated environments become a mixed waste. Defective unused fuel cells or spent fuel cells from Teledyne sensors in clean areas will be a hazardous waste.

Handling and Packaging: Store in a Satellite Area per RCRA requirements (40CFR262.34 (c)).

Annual Quantities:

\begin{tabular}{|r|r|r|r|r|}
\hline & & Waste Destination & & \\
\hline $0.03 \mathrm{ft}^{3}$ & $2 \mathrm{lb}$. & Hazardous to Off-site & $0.001 \mathrm{~m}^{3}$ & $0.9 \mathrm{~kg}$ \\
\hline $0.03 \mathrm{ft}^{3}$ & $3 \mathrm{lb}$. & Mixed to Off-site/Storage & $0.001 \mathrm{~m}^{3}$ & $1.4 \mathrm{~kg}$ \\
\hline
\end{tabular}

(a) Assume 2 spent cells per year in clean areas and 2 spent cells per year in tritiumcontaminated area.

(b) Assume clean spent cells shipped to off-site vendor in 1 gallon container.

- Assume 1 gallon containerized waste weighs $5 \mathrm{lb}$.

(d) Assume mixed cells macro-encapsulated in 1 gallon container for off-site vendor or storage.

(e) Assume macro-encapsulated waste form results in $50 \%$ weight increase.

\section{Waste Minimization:}

Product substitution to eliminate RCRA hazardous lead.

Treatment Options:

Hazardous Waste: Ship to a DOE-approved commercial treatment and disposal facility.

Mixed Waste: Macro-encapsulation followed by disposal in a RCRA Subtitle C facility.

\section{Comments:}

Current environmental regulations make it advantageous to avoid the generation of mixed waste. Use of a non-hazardous, non-lead substitute product appears to be the most practical solution. 


\section{B7. Mired and Hazardous Waste Oil/Solvent}

Type: Mixed Low-Level Waste, Hazardous Waste.

Description: Lubricating oil and solvents used for decontamination, cleaning, degreasing, spill clean-up and various maintenance activities may contain RCRA hazardous or listed components. Contamination with tritium and/or other radioactive components produces a mixed waste. Lubrication oil is used in vacuum pumps, blowers, robotic equipment, and vehicles operated in process buildings. Due to bearing wear or the tendency of oil to accumulate organic contaminants, waste oils have been found to contain the following RCRA codes: D005, D006, D008, D009, D018, F001, F003, F004, and F005. If falling mercury drop pumps or mercury diffusion pumps are used, mercury contamination (D009) will be present. Past experience at SRS has shown pump oil associated with tritium facilities can have tritium activity levels ranging from background to $185 \mathrm{Ci} /$. Residues of solutions used for decontamination, cleaning, or degreasing during equipment maintenance or repair may also be mixed waste. The solvents may be inherently hazardous and/or may become contaminated with radioactive or hazardous materials during the cleaning process.

Generation: Routine analytical, process operation, maintenance, cleaning, degreasing, and decontamination activities.

Handling and Packaging: Segregate and store in a Satellite Accumulation Area per RCRA requirements (40CFR262.34(c)).

Annual Quantities: Minimal.

\section{Waste Minimization:}

(a) Product substitution, to eliminate RCRA hazardous solvents.

(b) Change to mechanical/physical stripping/cleaning devices to avoid solvent use.

(c) Use of fluidless, all-metal pumps (e.g. Nometex) for tritium pumping.

(d) Use of oil-free blowers for discharges to stacks.

(e) Use of cooling system pumps that are water-cooled and lubricated.

\section{Treatment Options:}

(a) Incineration at CIF, followed by stabilization or vitrification of ash.

(b) Stabilization. Considering that the annual volume estimate is small, just stabilization may be more practical. 


\section{Hazardous Waste:}

(a) Energy recovery at the SRS power house, if halogen compounds are within allowable limits.

(b) Ship to a DOE-approved commercial treatment and disposal facility.

\section{Comments:}

(a) Used oil is regulated as a hazardous waste in the State of California.

(b) Current environmental regulations make it advantageous to avoid the generation of mixed waste. Use of non-hazardous oils for equipment and non-hazardous cleaning agents is highly advisable. For example, a new, non-hazardous and environmentally safe solvent for cleaning metal surfaces is available through Organitec, a Tennessee-based company.

(c) While thermal de-sorption of volatile organics may convert a mixed waste to a low-level waste, if the off-gases are adsorbed on activated carbon, the spent carbon bed becomes a secondary waste stream.

(d) Fluidless Nometex pumps are being used for certain applications n 233-H, replacing mercury diffusion pumps and Sprengel falling mercury drop pumps used in the past in 234-H. Double containment bellow-sealed pumps and fluidless, all-metal scroll pumps are viable candidates. However, these pumps are sensitive to particulate, chemical, and mercury attack, so the process lines must be kept very clean.

(e) With the exception of compressors, 233-H tritium process pumps do not use mercury or organic lubricants. 


\section{B8. Analytical Laboratory/Rad Con Chemicals}

Type: Hazardous, or Mixed Low-level Waste.

Description: Used, excess, or out-of-date chemicals used by Analytical Laboratories and Rad Con in Tritium. The chemicals identified in this waste stream are considered hazardous and may be solids, liquids, or gels. Gas standards and other pressurized gases are excluded. A variety of hazardous waste codes are possible.

Generation: Routine analytical chemistry and radiological control procedures needed to support operations of the Tritium Purification Process. Used chemicals are hazardous and may become a mixed waste, if used in a tritium-contaminated environment. These chemicals are used by Analytical Lab and Rad Con and reported in the draft 1996 Tier II Hazardous Chemical Inventory Report, Table B2

\section{Annual Quantities:}

Since consumption of these chemicals will result in discharges to the H-Area liquid Effluent Treatment Facility, building HVAC, job control waste, tritiated oil, etc., the projected quantities below are considered to be reflected and included in the other waste streams. One chemical, OptiFluor, constitutes more than $75 \%$ by weight and results are reported with and without it.

\begin{tabular}{|r|r|c|r|r|}
\hline $45 \mathrm{f}^{3}$ & $2,762 \mathrm{lb}$ & Total & $1.3 \mathrm{~m}^{3}$ & $1,256 \mathrm{~kg}$ \\
\hline $10 \mathrm{ft}^{3}$ & $644 \mathrm{lb}$. & Excluding Opti-Fluor & $0.3 \mathrm{~m}^{3}$ & $293 \mathrm{~kg}$ \\
\hline
\end{tabular}

(a) Annual usage estimated based on $4 x$ average inventory. See Table B2 for distribution.

(b) Assumed an average $S p G=1$, or $62.3 \mathrm{lb} / \mathrm{ft}^{3}$.

Waste Minimization:

(a) Use micro-analytical equipment to minimize chemical usage.

(b) Buy only require amounts to minimize disposal of expired excess chemicals.

Treatment Options:

Will be a function of the type of chemical; e.g., solid, liquid, acid, base, etc.

Comments: None. 
Tritium Facilities Modernization \& Consolidation Project

Process Waste Assessment
WSRC-TR-97-00368,Rev.0

November 14,1997

Table B2

Tritium Analytical Laboratory/Rad Con

Tier II Hazardous Chemical Inventory

(10/96)

\begin{tabular}{|c|c|c|c|c|}
\hline Chemical & Manufacturer & $\begin{array}{c}\text { Average } \\
\text { Inventory } \\
\text { lb. }\end{array}$ & $\begin{array}{c}\text { Maximum } \\
\text { Inventory } \\
\text { lb. }\end{array}$ & $\begin{array}{c}\text { Estimated } \\
\text { Usage* } \\
\text { lb./yr }\end{array}$ \\
\hline ABC Dry Chemical & Amerex & 10 & 10 & 40.0 \\
\hline Aero Clearview Glass Cleaner & ABC Compounding & 2.4 & 2.4 & 9.6 \\
\hline Aero Ammoniated Glass Cleaner & ABC Compounding & 0.7 & 0.75 & 3.0 \\
\hline Aero Lemonair Air Freshner & ABC Compounding & 0.65 & 0.7 & 2.6 \\
\hline Alconox & Alconox & 2 & 4 & 8.0 \\
\hline $\begin{array}{l}\text { All Pro AP210 Lemon Yellow Spray } \\
\text { Paint }\end{array}$ & Major Paint & 0.75 & 0.75 & 3.0 \\
\hline All Pro AP230 Orange Spray Paint & Major Paint & 0.75 & 0.75 & 3.0 \\
\hline Apiezon Products & James E. Biddle & 4.4 & 4.4 & 17.6 \\
\hline Ax-It-Plus Stripper & Betco & 3.0 & 3.0 & 12.0 \\
\hline Brillo Soap Pads & Purex Industrial & 1 & 1 & 4.0 \\
\hline Comet Cleanser & Proctor \& Gamble & 2 & 2 & 8.0 \\
\hline CRC 3-36 Aerosol & CRC Industries & 1 & 1 & 4.0 \\
\hline Dow Corning Multi-purpose Sealant & Dow Corning & 1 & 1 & 4.0 \\
\hline Dow Corning High Vacuum Grease & Dow Corning & 1.6 & 1.6 & 6.4 \\
\hline Duo-seal Vacuum Pump Oil & $\begin{array}{l}\text { Welch Vacuum } \\
\text { Technology }\end{array}$ & 2.0 & 2.0 & 8.0 \\
\hline Easy-off Oven Cleaner & Reckitt \& Coleman & 1.2 & 1.2 & 4.8 \\
\hline Enviro-Tech Precision Dusting & Tech Spray & 7.5 & 7.5 & 30.0 \\
\hline Ethanol USP-190 proof & $\begin{array}{l}\text { AAPER Alcohol \& } \\
\text { Chemical }\end{array}$ & 4.8 & 5.0 & 19.2 \\
\hline Ethylene Glycol & Mallinckrodt & 0.1 & 0.1 & 0.4 \\
\hline Inlet 19 Vacuum Pump Oil & $\begin{array}{l}\text { Inland Vacuum } \\
\text { Industries }\end{array}$ & 20.0 & 20.2 & 80.0 \\
\hline Isoclean Concentration & Isolab & 2.2 & 2.2 & 8.8 \\
\hline Joy Liquid Dishwashing Detergent & Proctor \& Gamble & 1 & 1 & 4.0 \\
\hline Kimwipes lens cleaning solution & Kimberly-Clark & 1.75 & 1.75 & 7.0 \\
\hline Leak-Tec 277C & $\begin{array}{l}\text { American gas \& } \\
\text { Chemical } \\
\end{array}$ & 1.3 & 1.35 & 5.2 \\
\hline Mechanical Pump Oil 15 & $\begin{array}{l}\text { Edwards High } \\
\text { Vacuum }\end{array}$ & 7.3 & 7.4 & 29.2 \\
\hline
\end{tabular}

${ }^{*}$ Estimated annual usage based on $4 \mathrm{x}$ average inventory. 
Tritium Facilities Modernization \& Consolidation Project

WSRC-TR-97-00368,Rev.0

Process Waste Assessment

November 14,1997

Table B2 (Cont'd)

Tritium Analytical Laboratory/Rad Con

Tier II Hazardous Chemical Inventory

(10/96)

\begin{tabular}{|c|c|c|c|c|}
\hline Chemical & Manufacturer & $\begin{array}{c}\text { Average } \\
\text { Inventory } \\
\text { lb. } \\
\end{array}$ & $\begin{array}{c}\text { Maximum } \\
\text { Inventory } \\
\text { lb. } \\
\end{array}$ & $\begin{array}{c}\text { Estimated } \\
\text { Usage* } \\
\text { lb./yr }\end{array}$ \\
\hline Mercury Spill Clean-up Kit & JT Baker & 2.5 & 2.5 & 10.0 \\
\hline $\begin{array}{l}\text { Met-L-X Dry Powder Extinguisher } \\
\text { Agent }\end{array}$ & $\begin{array}{l}\text { Ansul Fire } \\
\text { Protection }\end{array}$ & 53.7 & 53.7 & 214.8 \\
\hline Mighty X Wax Stripper & AMREP & 1.4 & 1.5 & 5.6 \\
\hline NoKoRude Soldering Paste & M.W. Dunton & 1.0 & 1.0 & 4.0 \\
\hline Opti-Fluor & Packard Instruments & 529.4 & 532.4 & 2117.6 \\
\hline RTV128 Silicone Rubber Sealant & General Electric & 0.2 & 0.2 & 0.8 \\
\hline $\begin{array}{l}\text { Rustmaster Spray Enamel OSHA } \\
\text { Orange }\end{array}$ & Glidden & 0.7 & 0.75 & 2.8 \\
\hline Santovac 5 Vacuum Pump Fluid & Monsanto & 0.25 & 0.3 & 1.0 \\
\hline Septisol Solution & Calgon Vestal Lab & 2.0 & 2.1 & 8.0 \\
\hline Sodium Hydroxide Solid & EM Science & 1.1 & 1.1 & 4.4 \\
\hline Superacrylic Spray Enamel & Sherwin Williams & 0.5 & 0.5 & 2.0 \\
\hline Trichlorofluoroethane & Allied Signal & 1.0 & 1.0 & 4.0 \\
\hline WBBM 55 Shredder Oil & Whitaker Brothers & 16.3 & 17.5 & 65.2 \\
\hline
\end{tabular}

*Estimated annual usage based on $4 x$ average inventory. 


\section{B9. Non-hazardous Tritiated Oil}

Type: Radioactive Liquid Waste, Low-level Radioactive Waste.

Description: Lubricating oil in pumps and other mechanical systems may become contaminated with varying amounts of tritium.

Generation: Waste oil is generated by preventative maintenance of oil pumps or compressors, chillers and gear boxes in tritium-processing systems. Future TFM\&C plans do not call for the use of pumps requiring oil which could become contaminated with tritium.

Handling and Packaging: Most tritiated oil contains tritium oxide and should be handled accordingly. Radioactive, non-hazardous waste oil is stored in Radiological Material Areas (RMAs) in small carboys (plastic containers) in secondary containment. Later the oil is consolidated in a 13-gallon carboy. Once the carboy is filled, a representative sample is taken for analysis. Determine acceptability of the oil for the SRS Power House (tritium activity limit 2000 $\mathrm{pCi} / \mathrm{ml}$ ) or the CIF (tritium activity limit $3,417 \mathrm{nCi} / \mathrm{g}$ ). Package the waste oil/fluid for transportation to the Power House or CIF; use an absorbent in the overpack to capture any liquid spills.

Annual Quantities:

\begin{tabular}{|r|r|c|r|r|}
\hline & & Waste Destination & & \\
\hline $3.3 \mathrm{ft}^{3}$ & $200 \mathrm{lb}$. & $\begin{array}{c}\text { Liquid form to Power } \\
\text { House/CIF }\end{array}$ & $0.1 \mathrm{~m}^{3}$ & $90 \mathrm{~kg}$ \\
\hline $6.6 \mathrm{ft}^{3}$ & $400 \mathrm{lb}$ & $\begin{array}{c}\text { Stabilized waste form to } \\
\text { LAW Vaults }\end{array}$ & $0.2 \mathrm{~m}^{3}$ & $180 \mathrm{~kg}$ \\
\hline
\end{tabular}

(a) Assume 50 gallons/yr, 50\% to CIF/power House and $50 \%$ need to be stabilized.

(b) Assume 25 gallons/yr stabilize to $2 x$ volume.

(c) Assume $\mathrm{SpG}=1$ or $62.3 \mathrm{lb} / \mathrm{ft}^{3}$ for weight calculations, for both liquid \& stabilized waste form.

Waste Minimization:

Use oil-less or low oil inventory pumps and equipment.

\section{Treatment Options:}

(a) Energy recovery at the SRS Power House.

(b) Non-hazardous tritiated waste oil with tritium concentration meeting CIF WAC will be incinerated at the CIF. 
Tritium Facilities Modernization \& Consolidation Project

(c) Stabilize and dispose in the EAV LAW Vaults.

\section{Comments:}

None. 


\section{B9a. Glovebox Bubbler Fluid}

\section{Type: Radioactive Liquid Waste, Low-level Radioactive Waste.}

Description: Glovebox bubblers contain a viscous liquid such as glycol or a silicone fluid. They are used as glovebox over pressure relief devices and also act as traps for removing contaminants from exiting glovebox atmosphere gases. The liquid in the bubblers is susceptible to tritium contamination. The liquids used in $233-\mathrm{H}$ glovebox bubblers are not currently regulated under RCRA as hazardous waste.

Generation: Bubblers are used as resealing pressure relief valves for gloveboxes. In the event of excessive glovebox pressure, gases will discharge through the bubblers rather than cause physical damage to the glovebox. Tritium in the glovebox atmosphere will readily exchange with the hydrogen atoms in the bubbler liquid. Tritium gloveboxes are normally maintained at a negative pressure relative to the room and tritium levels in the boxes are kept low. Therefore, little tritium activity should accumulate in the bubblers unless an over-pressure occurs.

Handling and Packaging: See Waste Stream B10.

Annual Quantities:

\begin{tabular}{|r|r|c|r|r|}
\hline & & Waste Destination & & \\
\hline $0.07 \mathrm{ft}^{3}$ & $4 \mathrm{lb}$. & Liquid form to CIF/Off-site & $0.002 \mathrm{~m}^{3}$ & $1.8 \mathrm{~kg}$ \\
\hline $0.13 \mathrm{ft}^{3}$ & $\mathbf{8 l b}$. & $\begin{array}{c}\text { Stabilized waste form to } \\
\text { LAW Vaults }\end{array}$ & $0.004 \mathrm{~m}^{3}$ & $3.6 \mathrm{~kg}$ \\
\hline
\end{tabular}

(a) Assume an average of 1 gallons/yr, $50 \%$ to Off-site and $50 \%$ need to be stabilized.

(b) Assume 0.5 gallons/yr stabilize to $2 \mathrm{x}$ volume.

(c) Assume SpG = 1 or $62.3 \mathrm{lb} / \mathrm{ft}^{3}$ for weight calculations, for both liquid and stabilized waste form.

Waste Minimization:

There is no feasible substitute for using bubblers as glovebox pressure relief valves.

Treatment Options:

(a) Stabilize bubbler liquid in an absorbent and send to EAV LAW Vaults for disposal..

(b) If tritium and halogen levels are acceptable, send to DDSI or SRS Power House for energy recovery or to SEG/CIF for incineration. 
Tritium Facilities Modernization \& Consolidation Project

Process Waste Assessment
WSRC-TR-97-00368,Rev.0

November 14,1997

\section{Comments:}

(a) Mound Laboratory uses glycol in their bubblers; SRS uses a more expensive silicone fluid.

(b) Consider changing to glycol for cost effectiveness and disposability. 


\section{B10. Classified Low Level Waste}

Type: Classified Low-level Waste.

Description: Tritium reservoirs, components and fragments.

Generation: The Life Storage Program examines production and R\&D reservoirs loaded with tritium. Reservoirs may be fracture tested, flow tested and dissected for metallurgical examinations.

Handling and Packaging: Handling and packaging of classified waste is sensitive information. Special arrangements must be made with Solid Waste for disposal.

Annual Quantities: Variable.

Waste Minimization:

(a) Optimize packaging configuration to minimize space requirement.

(b) Consider melting reservoirs, components and fragments to declassify waste and recycle metal.

\section{Treatment Options:}

(a) See (b) under Waste Minimization.

\section{Comments:}

None. 
Tritium Facilities Modernization \& Consolidation Project

Process Waste Assessment

WSRC-TR-97-00368,Rev.0

November 14,1997

\section{B11. Mixed Waste Mercury}

Type: Mixed Low-level Waste.

Description: Elemental mercury (D009) or mercuric oxide contaminated with tritium.

Generation: Mercury was used historically as a process fluid in pumps in the SRS Tritium Processing Facilities. Although 233-H RTF does not use any mercury pumps, mercury is used in manometers for pressure measurements and in certain thermostat switches.

Handling and Packaging: Store in a Satellite Area per RCRA requirements (40CFR262.34(c)).

Annual Quantities: None at this time.

Waste Minimization:

(a) Avoid introducing tritium and mercury-containing equipment into the TFM\&C facilities.

(b) Avoid using mercury-containing equipment (such as thermostats) inside the TFM\&C process gloveboxes through product substitution.

\section{Treatment Options:}

(a) Amalgamation of elemental mercury.

(b) Stabilization of mercuric oxide.

\section{Comments:}

This waste stream may be avoided by administrative controls and proper selection of mercury-free instruments and equipment. 


\section{B12. Palladium/Electrolysis Membrane}

\section{Type: Low-level Radioactive Waste.}

Description: Palladium membranes are used to separate impurity gases from hydrogen isotopes, without generating water. A palladium membrane reactor can also be used to recover tritium or hydrogen from waters or hydrogen oxides. Similarly, electrolysis is a technology that can be used for recovering elemental hydrogen isotopes from water vapors, without generating spent $\mathbf{M g}$ or $\mathbf{U}$ bed waste. Waste palladium reactor/electrolysis membranes will be contaminated with tritium.

Generation: Equipment failure or replacement of failed parts/modules. This waste stream will only be generated if either the palladium membrane reactor or the solid oxide electrolysis technology is adopted to replace $\mathrm{Z}$-bed recovery using a $\mathrm{Mg}$ bed or a $\mathrm{U}$ bed.

Annual Ouantities: None at this time.

Waste Minimization:

(a) Modular design to isolate potential failure elements, to avoid changing out the entire unit.

(b) Palladium membrane reactor and solid oxide electrolysis equipment should avoid use of RCRA metals in their construction.

Treatment Options:

Package for disposal in E-Area LAW Vaults.

\section{Comments:}

None. 


\section{APPENDIX C}

\section{Treatment and Disposal of TFM\&C Process Waste}

The major sources of tritium purification process waste are personal protection equipment (PPE) job control waste (JCW) from routine maintenance, and spent uranium or magnesium beds. The primary treatment for the JCW is incineration at the SRS Consolidated Incineration Facility (CIF) followed by cement stabilization of the ash residue or compaction followed by disposal in the SRS E-Area Vaults.

Solid waste containing RCRA characteristic metals not amenable to recycling would have to be encapsulated to minimize leaching after disposal, following EPA Hazardous Waste Codes (Appendix F ).

Appendix $\mathrm{C}$ describes the treatment and disposal options for tritium purification waste, evaluates relevant existing and planned treatment facilities at SRS and other DOE sites, and describes relevant waste treatment technologies for tritium purification process waste. This discussion is organized into the following sections:

C1. Tritium Purification Process Waste Disposition

C1.1 Low-Level Waste

C1.2 Mixed Low-Level Waste

C1.3 Hazardous Waste

C2. Existing and Planned SRS Waste Treatment, Storage and Disposal Facilities

C2.1 E-Area Vaults

C2.2 Consolidated Incineration Facility

C2.3 Hazardous/Mixed Waste Storage Pads/Buildings

C2.4 Sanitary Landfill

C2.5 Effluent Treatment Facility

C2.6 Sanitary Sewerage Treatment Facility

C2.7 Hazardous Waste/Mixed Waste Disposal Facility

C2.8 Prohibited Wastes

C3. Other DOE and Commercial Waste Treatment Facilities

C3.1 Hanford

C3.2 Nevada Test Site

C3.3 SEG

C3.4 DSSI

C3.5 Envirocare

C3.6 GTS Duratek

C4. Treatment Technologies

C4.1 Compaction

C4.2 Thermal Desorption

C4.3 Incineration 


\section{C4.4 Stabilization \\ C4.5 Vitrification \\ C4.6 Encapsulation \\ C4.7 Metals Recovery}

\section{C1. Tritium Purification Process Disposition}

The tritium purification process waste will be managed for treatment and disposal according to waste type. SRS and off-site or vendor-operated waste treatment, storage and disposal (TSD) facilities that may be used to treat, store or dispose of tritium purification process waste are shown in Fig. C-1. The tritium purification process -relevant TSD facilities are presented in plain shaded boxes. The shaded and shadowed boxes denote tritium purification process waste TSD facilities that are either off-site or at SRS but operated by vendors (Envirocare, GTS Duratek, Compaction and the Sanitary Landfill at SRS being developed by the Three River Solid Waste Authority).

Non- tritium purification process waste off-site and SRS waste streams and TSD facilities are shown in Fig. C-1 for information only and for completeness. These wastes and facilities include: TRU Waste, High-Level Waste, In-Tank Precipitation (ITP)/Late Wash, Defense Waste Processing Facility (DWPF), Saltstone, TRU Storage Pads, DWPF Storage Building, Saltstone Vaults, and the Burial Grounds, which were previously used for low-level radioactive waste (LLRW) disposal, but which have been replaced by the E-Area Vaults. Off-site waste facilities of interest under development are the Waste Isolation Pilot Plant (WIPP) for TRU waste disposal in New Mexico and the Yucca Mountain HLW repository in Nevada.

\section{C1.1 Low-Level Waste}

The radioactive waste generated by the tritium processing and metallurgical activities is expected all to be low-level radioactive waste. Tritium process LLRW is expected to be all contact-handled. The only significant radioactive contaminant should be tritium. This waste will consists mostly of job control waste (shoe covers, plastic sheeting, gloves, plastic suits, kraft paper, absorbent wipes, etc.) from process operations and analytical waste with trace tritium contamination, as well as more highly tritium-contaminated process equipment waste (piping, valves and fittings, gauges, pumps, metal hydride beds, catalyst beds, and zeolite beds). The only routine process waste should be spent magnesium beds, if $z$-bed recovery technology stays with magnesium beds rather than going with palladium membrane reactor, and sacrificial SAES St 909 getters from the tritium process stripper system.

All containerized SRS LLRW are projected to be disposed of in the E-Area Vaults (EAV). The EArea Vaults are divided into Low-Activity Waste (LAW) Vaults, Intermediate Level Tritium Vaults (ILTV), and Intermediate Level Non-Tritium Vaults (ILNTV). The ILTV are further divided into ILTV silos and ILTV Bulk Cell. LLRW with tritium content of less than $1000 \mathrm{Ci}$ and minimal tritium off-gassing (less than $4 \mathrm{E}-5 \mathrm{mCi} / \mathrm{cc}$ ) may be disposed of in B-25 containers in the LAW vaults. The LLRW spent target waste from extraction is proposed to be disposed of in the ILTV silos originally designed for current SRS extraction spent melt/crucible waste. These silos have a current disposal limit of 290,000 curies of tritium per silo and 190,000 Ci of Co-60, per interim WAC 3.17, effective 9/30/97.

The TFM\&C process and metallurgical LLRW designated for the E-Area Vaults disposal must meet WAC 3.17 of the WSRC 1S Manual. Since all TFM\&C radioactive waste are fundamentally the same as, or very similar to, waste already being generated. by current SRS Defense Program 
tritium production/laboratory activities, no problem is anticipated in meeting WAC3.17. However, if the EAV WAC 3.17 cannot be met, either 1) an exemption would have to be granted, 2) the WAC limits would have to be revised, or 3) a new waste disposal facility would have to be built to accommodate this waste. In that case, development of a new WAC would require conducting a Radiological Performance Assessment to determine long term waste disposal impact on the groundwater and post-institutional control intruders.

The low-activity tritium-contaminated job control waste may also be segregated for either off-site or on-site compaction, or incineration at the Consolidated Incineration Facility (CIF), prior to disposal in the EAV. Incinerable tritium purification process waste going to the CIF must meet the CIF waste acceptance criteria (WAC3.13 in WSRC 1S Manual). Off-site compaction is allowed. On-site waste compaction using the compactor in Building 253-H has been suspended.

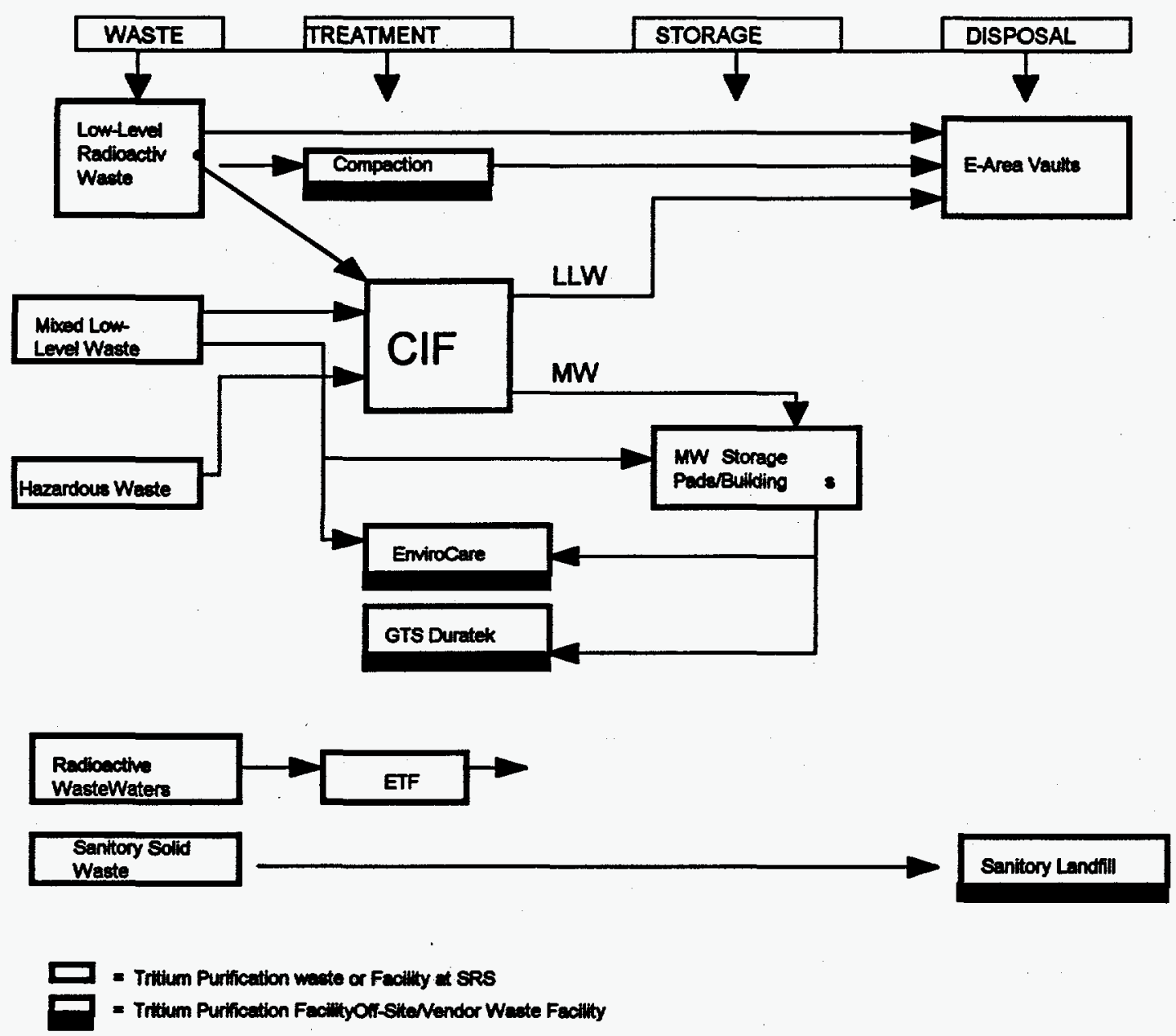

Fig. C-1 TFM \& C Process Waste Management Facilities 


\section{C1.2 Mired Low-Level Waste}

Incinerable TFM\&C mixed low-level waste with low rad contamination and trace amounts of RCRA metals will be treated in the CIF. Non-incinerable wastes such as surface-contaminated lead may be sent to a commercial vendor such as Envirocare for macroencapsulation. GTS Duratek is a potential vendor for vitrifying mixed waste in the future; it has a contract to vitrify SRS M-Area mixed waste sludges.

No DOE facility is currently authorized to dispose of MLLW on site, however, some shipments of MLLW to Hanford for storage have been allowed by DOE on a case-by-case basis. These shipments have been primarily either mixed waste containers whose surface dose rate exceeded 200 $\mathrm{mrem} / \mathrm{hr}$ and therefore required remote handling, "special waste", defined as waste that requires special handling, or unique waste, such as decommissioned reactor vessels. Hanford, NTS and Savannah River all have planned MLLW disposal facilities that have passed Key Decision-zero or $\mathrm{KD}-0$. This means that these sites have a recognized mission need and have been approved for funding for conceptual design of mixed waste disposal facilities. However, these projects have been placed on hold and DOE is revising its strategy for mixed waste disposal.

\section{C1.3 Hazardous Waste}

Incinerable tritium separation/purification process hazardous waste that meet the CIF WAC 3.13 will be incinerated in the CIF. Per current practice, other TFM\&C hazardous waste can be disposed of at any number of DOE or SRS-approved commercial facilities.

\section{C2. Existing and Planned SRS Waste Treatment, Storage and Disposal Facilities}

\section{C2.1 E-Area Vaults (EAV)}

The E-Area Vaults at SRS are designed to dispose of low-level and intermediate level radioactive waste. Intermediate-level waste is a subset of low-level waste. The term is used to designate lowlevel waste that have high levels of gamma activity and that may require non-contact handling.

As stated in C1.1, the E-Area Vaults are divided into the Low-Activity Waste (LAW) Vaults, the Intermediate Level Tritium Vaults (ILTV), which include a Bulk Cell and Tritium Silos, and the Intermediate Level Non-Tritium Vaults (ILNTV). Within the boundary of the EAV is a storage building for long-lived radioisotope waste such as reactor ion exchange resin containing C-14 and areas set aside for shallow land or trench burial of containerized Naval Reactor waste components and other cemented waste forms.

LLRW with tritium content of less than $1000 \mathrm{Ci}$ and minimal tritium off-gassing (less than $4 \mathrm{E}-5$ $\mathrm{mCi} / \mathrm{cc}$ ) may be disposed of in B-25 and other approved containers in the LAW Vaults. The LAW Vaults building in operation is approximately 650 feet by 145 feet by 25 feet in height $(200 \mathrm{~m} \mathrm{x}$ $44 \mathrm{~m} \times 8.2 \mathrm{~m}$ ) and is divided into 12 cells. The concrete end and side walls are 24 " thick. The concrete interior walls and base slab are 12 " thick. The LAW Vaults building has storage capacity for 12,000 B-25 containers, stacked 4 high. The original plans were to construct 21 vaults of this design. Due to successful waste minimization efforts at SRS and cost considerations, the number of vaults will likely be scaled back.

The Intermediate Level Vaults are subsurface concrete structures designed to handle and dispose of non-contact waste. Two of the seven ILV cells are designed specifically to handle tritium waste: a bulk cell and a cell containing 140 silos designed to accept tritium extraction crucible waste. The 
ILV base slab, side and end walls are constructed of 30" concrete. The interior walls are 20" concrete. The ILTV bulk cell is approximately 50 feet by 25 feet by 29 feet in height $(15.2 \mathrm{~m} \mathrm{x}$ $7.6 \mathrm{~m} \times 8.8 \mathrm{~m}$ ). It is used for disposal of tritiated waste which contains more than 1000 curies of tritium per container, usually waste equipment such as zeolite beds and diffusers. The tritium silos are approximately 20 feet deep and tapered from $30^{\prime \prime}$ to 20 " in diameter at the bottom (SRS Drawing W2020320). Top shielding for the silos are provided by $40^{\prime \prime}$ thick concrete plugs. The ILTV silos have a current disposal limit of 290,000 curies of tritium each (WAC3.17, 9/30/97). Classified tritium waste is also disposed of in the ILTV.

The E-Area Vaults are operated by the Solid Waste Division. The governing WAC is WAC 3.17 of the 1S Manual.

\section{C2.2 Consolidated Incineration Facility (CIF)}

The Consolidated Incineration Facility, located between S-Area and H-Area at the SRS, is designed to incinerate both solid and liquid wastes from several generators around the SRS. Liquid waste can be sent by container or pipeline. Solid waste for incineration should be packaged in standard 21 " $\times 21$ " $\times 21$ " cardboard boxes.

The CIF is a rotary kiln incinerator with a secondary combustion chamber. The liquid waste is fed into both the rotary kiln's primary combustion chamber and the secondary combustion chamber. Solid waste is fed into the primary combustion chamber. Organic materials are combusted to water and carbon dioxide. Off-gas is quenched, scrubbed in a caustic solution and discharged to the atmosphere.

Non-combustible ash materials are collected, mixed with Portland cement and other stabilizing additives, and cast into stable solid waste forms referred to as "ashcrete". The ashcrete system also stabilizes blowdown liquid from the quench and scrubber ("blowcrete"). The ashcrete system could also be used to encapsulate other small waste components that could be mixed directly with the ash.

The estimated CIF thermal capacity of 18 million BTU/hr is based on the design estimate of wastes expected to be in inventory at the time of CIF start-up and on wastes expected to be generated annually after CIF start-up. To maximize the flexibility and utilization of the CIF, the material handling systems for feeding solid and liquid wastes were sized for a greater throughput than the average annual requirement for each system. The instantaneous capacity of the individual subsystems are as follows:

- Solid waste to rotary kiln

- Organic liquid waste to rotary kiln

- Aqueous liquid waste to rotary kiln

- Organic liquid waste to secondary combustion chamber
$2025 \mathrm{lbs} / \mathrm{hr}$

$385 \mathrm{lbs} / \mathrm{hr}$

$950 \mathrm{lbs} / \mathrm{hr}$

$302 \mathrm{lbs} / \mathrm{hr}$

The CIF can generally treat any combination of liquids and solids up to the rates listed above, provided that the thermal capacity and other operational limits are not exceeded. The CIF is expected to have excess capacity for treating other SRS and non-SRS DOE incinerable wastes. The schedule for treating other wastes at CIF will be established based on several key factors, including: 
- Available thermal capacity

- Concentrations of waste constituents (e.g., hazardous metals) that are controlled by the various CIF environmental permits.

- Concentrations of waste constituents (e.g., chlorides and non-combustibles) that directly influence the amount of bottom ash and off-gas scrubber blowdown generated. When wastes that generate significant ash or blowdown are incinerated, the demand on the spare ashcrete unit capacity could become the factor that limits waste feed rates.

The nominal capacities for CIF are $3.5 \times 10^{6} \mathrm{ft}^{3} / \mathrm{yr}\left(100,000 \mathrm{~m}^{3} / \mathrm{yr}\right)$ of solid waste feed and 12,000 $\mathrm{ft}^{3} / \mathrm{yr}\left(340 \mathrm{~m}^{3} / \mathrm{yr}\right)$ of liquid waste feed.

The CIF is operated by the Solid Waste Division. The governing WAC is WAC 3.13 in the SRS IS Manual.

\section{C2.3 Hazardous/Mixed Waste Storage Pads/Buildings}

Tritium purification process hazardous and mixed waste that cannot go directly to an off-site vendor for treatment may be stored in a number of storage pads or buildings. Current mixed waste storage facilities include Mixed Waste Storage Buildings 643-29E and 643-43E in E-Area, 645-2N near the Central Shops, and 315-4M and 316-M in M-Area. Mixed waste storage pads are located in the Solid Waste Disposal Facility. Hazardous waste is currently stored at the SRS Waste Management Hazardous Waste Storage Facility. This facility includes Building 645-N and 6454N near the Central Shops, Building 710-B in B-Area and Solid Waste Storage Pads 1, 2 and 3.

Hazardous and mixed waste management is the responsibility of the Solid Waste Division. The governing WACs in the WSRC 1S Manual are WAC 3.07 for mixed waste storage and WAC 3.08 for hazardous waste storage.

\section{C2.4 Sanitary Landfill}

The TFM\&C facility solid sanitary waste is expected to go to a sanitary landfill located on the SRS. The Three River Solid Waste Authority is developing an 1100-acre site on the SRS for a regional landfill. It is anticipated to be in operation prior to the start-up of tritium purification process operations. It will provide capacity for receiving sanitary waste from an 8-county area around SRS. It will also provide for demonstrating state-of-the art treatment technologies for solid waste. The landfill should be a subtitle D landfill with double liners and a leachate collection system.

Sanitary waste management is the responsibility of the Solid Waste Division. The governing WAC is WAC 3.09 in the SRS 1S Manual.

\section{C2.5 Effluent Treatment Facility (ETF)}

The Effluent Treatment Facility (ETF), Building 241-81H, located off Road E near the H-Area Tank Farm at the SRS, is a multi-purpose plant for treating highly diluted aqueous waste. Waste generally arrives at ETF by pipeline. There are proposals to provide a station for unloading liquid waste from containers or tank cars. The ETF consists of a number of separation steps, including ultrafiltration, carbon bed filtration and ion exchange

To determine the compatibility or suitability of a proposed new liquid waste stream with the ETF ion exchange process, a treatability andy is first conducted to determine the compatibility of the 
constituents of concern with the ion exchange resin that will be used for absorption. The waste is pumped from the feed tank to the ion exchange beds. The constituents of concern should bind tightly to the ion exchange resins to pass TCLP, allowing the spent resin to be disposed of as a non-hazardous low-level waste. Carbon beds are designed to remove dissolved organics from wastewaters. They can also remove some dissolved metal and other inorganic contaminants.

Decontaminated ETF liquid effluent is collected in tanks for analysis, which should confirm that the liquid meets release specifications and NPDES limits. Liquid that meets specifications is released to a surface outfall. In the unlikely event that the treated effluent fails to meet release specification, it can be recycled for reprocessing. No liquid is released without passing a final assay.

The ETF has a demonstrated maximum throughput of about $130 \mathrm{gpm}$. Acceptance of waste streams at ETF is on a case-by-case basis, depending on the quantity of waste and concentration of the constituent of concern. Since the ETF processes cannot remove tritium, it is suggested that tritium content in tritium purification process liquid effluent to the ETF should be less than [TBD] $\mathrm{mCi} /$ liter.

The ETF is operated by the High-Level Waste Division. There are currently no formal WACs that apply to the ETF.

\section{C2.6 Sanitary Sewage Treatment Facility}

Sanitary sewage at SRS is treated at a centralized facility near F-Area and at a number of local facilities. Existing 233-H and 234-H sewage is piped and pumped to the central sanitary facility constructed in 1995. Sewage is processed using an oxidation ditch, an intra-channel clarifier, chlorination, settling ponds, and ultraviolet disinfection. The sewage treatment facility has a capacity for processing 1.05 million gallons per day.

The sanitary sewage treatment facilities are operated by Site Services Division. There is no currently WAC for this facility.

\section{C2.7 Hazardous Waste/Mixed Waste Disposal Facility (HW/MW DF)}

The Hazardous Waste/Mixed Waste Disposal Facility (HW/MW DF) at SRS was a line-item project whose status is uncertain at this point. A project re-scoping that will impact cost and schedule was submitted to DOE and no action has been taken. NEPA documentation was prepared for the HWMW DF. A decision by DOE as to whether an Environmental Assessment or Environmental Impact Statement will be required is also pending. Until the NEPA and project scope questions have been answered, schedule and milestones cannot be defined. It is possible that this project may be canceled.

As currently designed, the HW/MW DF will include treatment systems for waste handling (sorting and size reduction), acid leaching and chemical precipitation, stabilization of solid and liquid wastes, soil washing, macro-encapsulation of lead, roasting/retorting of mercury-contaminated soil and equipment, amalgamation of elemental mercury, and wastewater cleanup. Systems applicable to treatment of the tritium purification process waste are the macro-encapsulation and stabilization units. 


\section{C2.8 Prohibited Wastes}

The waste destined for a particular treatment, storage or disposal facility at SRS must, in general, meet the Waste Acceptance Criteria of that facility. Exemptions or deviations may be granted in the case of noncompliance. For general guidance, Savannah River Site waste treatment, storage and disposal facilities will not accept the following for disposal, without special approval:

- Aerosol cans (pressurized, non-empty)

- Compressed gas cylinders

- Biologic, pathogenic or infectious materials

- Waste that can detonate or explode

- Waste that can generate toxic fumes or gases

- Incompatibles wastes in the same container

- Pyrophorics

- Shock sensitive waste

- Waste containing cyanide or sulfides not chemically bound

- Wastes that are only corrosive (D002) must be neutralized prior to disposal

- Uncontainerized waste

- Wastes containing polychlorinated biphenyls $\geq 50 \mathrm{ppm}$ (TSCA waste)

- Unidentified, uncharacterized, or poorly characterized waste.

In addition, non-hazardous waste should not be sent to the hazardous waste facility and sanitary waste should not be sent to the EAV.

For definitive guidance, the reader should refer to the complete set of Waste Acceptance Criteria for the specific waste treatment, storage and disposal facility of interest.

\section{C3. Other DOE and Commercial Waste Treatment Facilities}

In addition to SRS, several other.DOE sites are capable of treating and/or disposing of low-level and mixed low-level waste. Several commercial vendors have also been approved for treating lowlevel and mixed low-level wastes.

Relevant treatment facilities for tritium purification process waste at SRS and Oak Ridge are summarized in Table Cl. The Nevada Test Site (NTS) is a potential disposal site for low-level waste, but has no on-site treatment facilities. Pantex has only encapsulation facilities. Hanford and LANL have existing and/or planned compaction capabilities. Only those facilities that have at least passed DOE KD-0, Approval of Mission Need, are listed. Typically at this stage, conceptual design and the preparation of NEPA documentation have been initiated. 
Tritium Facilities Modernization \& Consolidation Project

WSRC-TR-97-00368, Rev.0

Process Waste Assessment

November 14,1997

Table C1

Existing and Planned DOE Waste Treatment Facilities

Relevant for TFM\&C Process Waste

\begin{tabular}{|c|c|c|c|c|c|}
\hline Site & Facility & Treatment(s) & $\begin{array}{c}\text { Allowable } \\
\text { Waste }\end{array}$ & $\begin{array}{c}\text { Design } \\
\text { Capacity } \\
\mathrm{m}^{3} / \mathrm{yr}\end{array}$ & $\begin{array}{c}\text { Estimated } \\
\text { Start-up Date }\end{array}$ \\
\hline \multirow[t]{4}{*}{ SRS } & $\begin{array}{l}\text { Consolidated } \\
\text { Incineration } \\
\text { Facility } \\
\text { (CIF) }\end{array}$ & Incineration & $\begin{array}{l}\text { Low-level } \\
\text { Mixed }\end{array}$ & $\begin{array}{l}100,424 \text { solids } \\
340 \text { liquids }\end{array}$ & $\begin{array}{l}\text { Undergoing } \\
\text { start-up }\end{array}$ \\
\hline & $\begin{array}{l}\text { CIF Ashcrete } \\
\text { Facility }\end{array}$ & Stabilization & $\begin{array}{l}\text { Low-level } \\
\text { Mixed }\end{array}$ & 2,426 & $\begin{array}{l}\text { Undergoing } \\
\text { start-up }\end{array}$ \\
\hline & 253-H Compactor & Compaction & Low-level & 1,600 (est) & $\begin{array}{l}\text { TBD for } \\
\text { restart }\end{array}$ \\
\hline & $\begin{array}{l}\text { Hazardous } \\
\text { Waste/Mixed } \\
\text { Waste Disposal } \\
\text { Facility }\end{array}$ & $\begin{array}{l}\text { Macroencapsul } \\
\text { ation, } \\
\text { Stabilization }\end{array}$ & $\begin{array}{l}\text { Low-level } \\
\text { Mixed }\end{array}$ & $\begin{array}{l}73 \text { (macro.) } \\
484 \text { (stab.) }\end{array}$ & $\begin{array}{l}\text { Project on- } \\
\text { hold }\end{array}$ \\
\hline \multirow[t]{2}{*}{ Hanford } & $\begin{array}{l}\text { Waste Receiving } \\
\text { \& Processing } \\
\text { Facility, WRAP I }\end{array}$ & $\begin{array}{l}\text { Compaction } \\
\text { Stabilization }\end{array}$ & Low-level & 1400 & Operational \\
\hline & $\begin{array}{l}\text { Waste Receiving } \\
\text { \& Processing } \\
\text { Facility, WRAP } \\
\text { II }\end{array}$ & $\begin{array}{l}\text { Macroencap- } \\
\text { sulation, } \\
\text { Stabilization }\end{array}$ & $\begin{array}{l}\text { Low-level, } \\
\text { Mixed }\end{array}$ & 1500 & FY99 \\
\hline \multirow[t]{2}{*}{ INEL } & \begin{tabular}{|l|} 
Waste \\
Experimental \\
Reduction \\
Facility, WERF \\
\end{tabular} & $\begin{array}{l}\text { Incineration } \\
\text { stabilization }\end{array}$ & $\begin{array}{l}\text { Low-level, } \\
\text { Mixed }\end{array}$ & $\begin{array}{l}49,625 \text { (incin.) } \\
2765 \text { (stab.) }\end{array}$ & Operational \\
\hline & $\begin{array}{l}\text { HEPA Filter } \\
\text { Leaching System }\end{array}$ & $\begin{array}{l}\text { Chemical } \\
\text { Extraction }\end{array}$ & $\begin{array}{l}\text { Low-level, } \\
\text { Mixed }\end{array}$ & 83 & TBD \\
\hline Oak Ridge & TSCA Incinerator & Incineration & $\begin{array}{l}\text { Low-level, } \\
\text { Mixed }\end{array}$ & 15,716 & $\begin{array}{l}\text { Operating, } \\
\text { liquids \& } \\
\text { solids } \\
\end{array}$ \\
\hline \multirow[t]{2}{*}{ Pantex } & Building 11-9 & Encapsulation & $\begin{array}{l}\text { Low-level } \\
\text { Mixed }\end{array}$ & 43 & TBD \\
\hline & $\begin{array}{l}\text { Hazardous Waste } \\
\text { Treatment \& } \\
\text { Processing } \\
\text { Facility }\end{array}$ & $\begin{array}{l}\text { Compaction, } \\
\text { Stabilization, } \\
\text { Encapsulation }\end{array}$ & Low-level & 500 & FY98 \\
\hline
\end{tabular}


If DOE grants an exemption for shipment of tritium purification process waste to commercial treatment facilities, Diversified Scientific Services (DSSI) and Scientific Ecology Group (SEG), both in Oak Ridge, TN, could be utilized for low-level PPE/JCW waste streams. However, their tritium annual release limits are limited to less than $600 \mathrm{Ci}$. Both DSSI and SEG have thermal treatment facilities that can accept low-level, tritium-contaminated waste, and SEG also has stabilization and compaction capabilities. The Envirocare facility in Utah, though more distant from SRS, is another commercial vendor capable of treating tritium purification process mixed waste through macro-encapsulation or stabilization. DOE Order 5820.2A requires that all DOE LLW be disposed of at a DOE disposal facility, unless an exemption is obtained. Commercially treated tritium purification process mixed waste may have to be returned to SRS for storage and eventual disposal.

At the present time, three DOE disposal sites are known to accept off-site radioactive waste for disposal: SRS, Hanford, and the Nevada Test Site. Barring policy changes, TFM\&C process low-level waste that meets the site's WAC could be sent to one or more of these facilities. A formal application and approval process must be completed before waste can be shipped to any of these sites.

The WACs of facilities that could be used for disposal of tritium purification process low-level and mixed waste are summarized in the following discussion. All waste approved for off-site treatment and/or disposal must be packaged according to Department of Transportation regulations for shipping of hazardous and/or radioactive materials over public roadways.

All three sites require that, upon or immediately after generation and before packaging, the physical and chemical characteristics and radionuclide content of all LLRW be determined and recorded for use during all subsequent stages of the waste management process; i.e., on-site treatment, packaging, segregation, transportation, off-site treatment, storage and disposal. Additional site-specific requirements and restrictions may be found in the WAC for each site. General information about the WAC and contacts at the three DOE low-level and mixed waste disposal site is summarized below.

DOE Low-Level Waste Disposal Sites, Contacts and WACs

\begin{tabular}{|l|l|l|l|}
\hline Site & Location & Site Contact & WAC Document \\
\hline Savannah River & $\begin{array}{l}\text { Portions of Aiken, } \\
\text { Barnwell, and Allendale } \\
\text { Counties, SC }\end{array}$ & $\begin{array}{l}\text { Pam Jenkins } \\
(803) 725-1541\end{array}$ & WSRC-1S \\
\hline Hanford & Richland, WA & $\begin{array}{l}\text { Clay Hawkes } \\
(509) 372-0508\end{array}$ & WHC-EP-0063 \\
\hline Nevada Test Site & Nye County, NV & $\begin{array}{l}\text { Wendy Griffin } \\
(702) 295-5751\end{array}$ & NVO-325, Rev. 1 \\
\hline
\end{tabular}




\section{C3.1 Hanford}

The Hanford Waste Receiving and Processing Facilities (WRAP I and II) are designed to prepare on-site low-level waste (WRAP I) and mixed low-level waste (WRAP IIA) for disposal. WRAP I includes systems for adsorption, compaction, stabilization and packaging. WRAP II, which is at the KD-0 stage, will conduct waste grouting, macrocencapsulation and stabilization operations. An incineration facility with a design capacity of $19,400 \mathrm{ft}^{3} / \mathrm{yr}\left(550 \mathrm{~m}^{3} / \mathrm{yr}\right)$ is planned but not approved.

Hanford has established WAC WHC-EP-0063-4, UC-721 (November 1993) for off-site generators of radioactive waste interested in sending waste to Hanford.

\section{C3.2 Nevada Test Site (NTS)}

The Nevada Test Site (NTS) is a potential disposal site for low-level waste, but has no on-site treatment facilities. The NTS has established WAC NVO-325, Rev 1, June 1992, "Nevada Test Site Defense Waste Acceptance Criteria, Certification and Transfer Requirements," for off-site generators interested in sending waste to NTS.

\section{C3.3 Scientific Ecology Group (SEG)}

1560 Bear Creek Road, Oak Ridge, TN 37831-2530, Tel: (615) 481-0222

SEG transition from a Westinghouse operating unit to a subsidiary of GTS Duratek in 1997. The SEG facility near Oak Ridge, Tennessee, is permitted and capable of compacting, incinerating and stabilizing low-level radioactive waste. Other capabilities include metal melting, wet waste processing, decontamination, processing of sealed radioactive sources and drying/incineration of resins and sludges. SEG is not permitted to treat mixed waste from outside the state of Tennessee and it is not permitted as a disposal site.

The governing WAC for waste receipt and treatment at SEG is OP-4.35. Different wastes and treatments are governed by different packaging, receipt, waste form, radiation level and radiological criteria. Some tritium purification relevant criteria for compaction, incineration and metal melting are discussed below.

Generally, the following wastes are not acceptable for compaction:

- RCRAVTSCA hazardous wastes

- Explosives

- Pyrophoric materials

- Flammable solids

- Liquid

- Absorbed liquid

- Smoke detectors

- Gas containers

- Gas sources

- Aerosol cans (unless punctured)

- Animal/biological waste 


\section{- $\mathrm{Kr-85}$ Electron tubes}

Bulk and non-bulk dry active waste of most cellulosic and polymeric materials are acceptable for incineration. Materials not acceptable for incineration include the following:

- Sharps

- Metal

- Glass

- Polyvinyl chloride (PVC)

- Asbestos

- RCRATSCA hazardous wastes

- Explosives

- Pyrophorics

Contaminated oils and aqueous liquids are accepted for incineration. Contaminated oils acceptable for incineration include petroleum-based lubricating and heating oils such as kerosene, hydraulic oil, diesel fluid and other flammable oils. There are restrictions on viscosity, solids and aqueous liquid content, flash point and RCRA/TSCA limits. Of particular interest to tritium purification process waste is that the tritium content must be $\leq 3.0 \times 10^{-3} \mathrm{mCi} / \mathrm{ml}$ and halogens must be $\leq 1000$ ppm.

Similarly, aqueous liquids may be incinerated at SEG. There are restrictions on $\mathrm{pH}, \%$ solids, chelating agents and oil content, flash point and RCRAVTSCA limits. As with contaminated oil, the tritium content must be $\leq 3.0 \times 10^{-3} \mathrm{mCi} / \mathrm{ml}$.

\section{C3.4 Diversified Scientific Services, Inc. (DSSI)}

657 Gallaher Road, Kingston, Tennessee 37763, Tel: (423) 376-8702

DSSI is a subsidiary of Chemical Waste Management, Inc. The DSSI facility near Oak Ridge Tennessee is permitted and capable of energy recovery from low-level and mixed waste.

\section{C3.5 Envirocare}

46 West Broadway, Suite 240, Salt Lake City, Utah 84101, Tel: (801) 532-1330

Envirocare of Utah, Inc. is the only commercial facility in the United States permitted to accept MLLW for disposal. Envirocare is licensed to accept both low-level and mixed waste, including NRC Class A LLW, debris, by-product material (e.g., uranium and thorium mill tailings), and F. listed debris. Concentrations of listed contaminants must be below RCRA treatment standards. In addition to requiring a detailed description of the waste, its history, physical properties, and chemical and radioactive constituents, Envirocare requires that the following analytical data be supplied for each MLLW:

- Gamma spectral analysis for all naturally occurring and man-made radionuclides. If radionuclides are known to be present that cannot be easily quantified by gamma spectroscopy, radiochemical analysis must be provided.

- Paint Filter Liquids Test, EPA Method 9095, for dry solids and stabilized wastes.

- TCLP results for heavy metals and volatile and semi-volatile organics. 
- Proctor test for soils.

All analyses must be performed at either a laboratory approved by Envirocare or an EPA Contract Laboratory Program laboratory. Five 1-kg representative waste samples must be sent to Envirocare and may be analyzed by them prior to waste acceptance.

\section{C3.6 GTS Duratek}

A contract has been awarded to GTS Duratek to design, build and operate a vitrification process, which will transform SRS M-Area mixed wastes into a form meeting land disposal restrictions (LDRs). M-Area wastes that make up the design basis for the vitrification process are:

- M-Area plating line sludge from supernatant treatment

- M-Area high nickel plating line sludge

- M-Area treatability test samples

- Filtercake from Mark 15 filters

- Nickel plating line solution

- Plating line sump material

The above wastes will be blended into a homogenized mixture in existing tanks in $M$ Area. Stabilizing chemicals and glass-forming materials will be added to the mixture to make vitrification feedstock. The feedstock will be pumped into a melter at a temperature of about $1150^{\circ} \mathrm{C}$. The glass-forming materials chemically bond the constituents of concern into a matrix of borosilicate glass. The glass is placed into containers for storage and disposal. The entire operation takes place in a structure with secondary confinement and air emission control equipment.

The Duratek vitrification facility is sized for about 5 tons of throughput per day. After treating the M-Area waste it may be possible to treat other mixed or low-level waste streams, including tritium purification process wastes. To be a viable option, it is also assumed the service life of the vitrification facility may be extended. A new contract or contract modification would have to be established with GTS Duratek.

\section{C4. Treatment Technologies}

Treatment technologies applicable to TFM\&C waste include compaction, thermal desorption, incineration, stabilization, vitrification, encapsulation and metals recovery. The following descriptions of the technologies are taken from the APT Process Waste Assessment (SNL Report SAND94-2217, UC-721, September 1995). Several descriptions have been modified to apply more specifically to TFM\&C waste.

\section{C4.1 Compaction}

While the greatest volume reduction of PPE job control waste would be achieved through incineration, where this is not feasible, compaction should be seriously considered. During compaction a drum of waste may experience an area force of 4-5M lbs, depending on the equipment. Under this force, job control waste usually reaches a density of 55-60 lbs/ $\mathrm{ft}^{3}$ (880-950

$\mathrm{kg} / \mathrm{m}^{3}$ ). This corresponds to a volume reduction factor of 3-5. Trace amounts of tritium poses no particular problem for compaction of less contaminated waste, such as PPE job control waste. Compaction of SRS job control low-level waste has been done at SEG in Oak Ridge in 1996. Compacted waste was retumed to SRS for disposal in the EAV. 
To maximize utility of the EAV tritium bulk cell and silo capacities, volume reduction of HEPA filters, spent target rods, and baseplates, if any, is highly desirable. Target rod assemblies cut from baseplates will volume reduce to less than $1 / 2$ to $1 / 3$ of their original bulk volumes. HEPA filters may be compacted similarly to job control waste. One major consideration would be the activity level of the HEPA filter waste.

\section{C4.2 Thermal Desorption}

Thermal desorption consists of heating waste to a point where volatile liquid contaminants can be driven off. The vapor may be condensed by cooling or absorbed in activated carbon. Since waste containing $>1 \%$ free standing liquid is not acceptable for disposal, this process is often used to drive off residual liquid prior to waste compaction. If a radioactive waste is mixed due to the presence of organic solvents, thermal desorption removes the hazardous constituents, which by use of the debris rule, leaves a low-level waste. This treatment can potentially be used for TFM\&C waste streams such as absorbent wipes and solvent rags; however, if activated carbon is used, it becomes a secondary waste stream that must be treated (incinerated) or disposed of.

\section{C4.3 Incineration}

Incineration is the thermal decomposition of organic constituents through high temperature (760 $1550^{\circ} \mathrm{C}$ ) oxidation reactions. Hydrocarbon wastes are converted to carbon dioxide and water vapor; wastes containing nitrogen, sulfur, and/or halogens produce nitrites, nitrates, ammonia, sulfites, sulfates, and halogen acids, respectively. Air particulates are filtered and exhaust gases are cooled, scrubbed, and neutralized in an air emissions control system prior to release to the system exhaust stack. Ash residues can be stabilized in cement or vitrified into a glass-like solid for disposal.

Solid wastes are generally treated in a rotary kiln furnace or a fixed hearth furmace. Wastes are fed to the combustion chamber a number of different ways: using rams, gravity feed, air lock feeders, vibratory or screw feeders, or belt feeders. Containerized waste is gravity-fed or ram-fed. The rotary kiln furnace is a refractory or metal-lined cylinder, mounted at a slight incline from horizontal, that slowly rotates to enhance the mixing of solids with combustion air. A forced-draft air circulation system provides oxygen for combustion and turbulence for mixing. The rotation also moves the ash to the lower end of the kiln, where it is removed. Rotary kiln systems usually have a secondary combustion chamber, or afterburner, following the kiln, for further combustion of volatilized waste components.

Fixed hearth, or controlled air or starved air incineration, is a two-stage process. Waste is ram-fed into the primary chamber, where it is burned in a "starved" atmosphere whose oxygen content is insufficient for complete combustion. The products of incomplete combustion, primarily carbon monoxide and volatile hydrocarbons, pass into a secondary chamber where additional air is injected to complete the combustion process. Due to the reduced air flow in the primary chamber, combustion gas velocities are lower, and, as a result, there is less entrainment and carryover of ash particulates into the secondary chamber and the exhaust gases.

An innovative technology that has several advantages for incineration of radioactive waste is the plasma arc centrifugal furnace. This system uses plasma energy to vitrify material dropped into a tub spinning at 20-50 rpm. The tub has an axial hole for tapping slag, which cools into a glass-like solid that is a leach-resistant, homogeneous product. A metal layer forms on top of the slag, and 
can be drawn off separately. Organics are burned to completion in a secondary combustion chamber. The advantages of this system for radioactive waste treatment are:

- Whole drums of waste can be inserted and treated.

- Metals separation, combustion of organics and solidification of residue can be achieved with a single process.

- Because there is only one system, waste handling is minimized.

Incineration is the recommended treatment for incinerable TFM\&C job control waste. Shredding of this waste prior to combustion will increase combustion efficiency, however, it is not necessary and is not planned for feeding the CIF at this time. Incineration followed by vitrification or stabilization of residues will generally reduce the initial waste volume by about a factor of 20 . During trial burns, the Waste Experimental Reduction Facility (WERF) incinerator at the INEL achieved volume reduction factors as high as $\mathbf{8 0}$.

Incineration of tritiated waste will result in tritium contamination in the exhaust gases. Some of this will adhere to particulates and be trapped in the exhaust HEPA filters. As exhaust gases are rapidly cooled and water vapor condenses, some of the remaining tritium should be trapped by the scrubber system; however, most will go up the stack as tritiated water vapor (J. D. Brady, "Fate of Tritium, Carbon-14, and Iodine-131 in Wet Scrubber Air Pollution Control Systems on Chemical and Medical Waste Incinerators", 1992 Incineration Conference, Albuquerque, New Mexico, May 11-15, 1992.). Stack gas should be monitored so that the permitted tritium release limit is not exceeded. Exhaust gas filters and scrubber solutions will be secondary waste streams.

\section{C4.4 Stabilization}

Stabilization immobilizes hazardous heavy metals by chemically binding them in a solid matrix. This decreases the potential for metals to leach out after disposal if the waste were to be exposed to moisture or weak acids. The two most common stabilization agents are Portland cement and lime/pozzolan.

While cement-based products are commonly used for stabilization of inorganic solids and aqueous liquids, a series of non-hazardous compounds based on Montmorillonite clay can be used to stabilize aqueous liquids, organic liquids such as used oil, and organic/aqueous liquid mixtures. These compounds are sold under the trade names Aquaset and Petroset.

The estimated total annual volume of primary TFM \&C waste streams for which stabilization is the proposed treatment is small, $<3.5 \mathrm{ft}^{3}\left(0.1 \mathrm{~m}^{3}\right)$. This waste is primarily highly tritiated oil or water not suitable for the CIF.

\section{C4.5 Vitrification}

Vitrification produces a non-leaching stabilized waste form of high integrity and minimal secondary waste. Vitrification processes involve dissolving waste at high temperatures (1100 $1400^{\circ} \mathrm{C}$ ) in a pool of molten glass that usually consists of soda ash, lime, silica, boron oxide, and other glass-making constituents. Molten glass is periodically withdrawn from the bottom of the furnace and cooled. This process is an alternative to stabilization for immobilization of incinerator 
ash prior to disposal. Vitrification is also suitable for ion exchange resins, chemical cleaning and decontamination solutions, and inorganic sludges and slurries; however, from an energy use standpoint, it is only practical for large volume waste streams that will be generated on a regular basis.

Vitrification is an effective means of immobilizing both hazardous inorganic and radioactive constituents. Both alpha and beta emitters will be sealed in the glass matrix, and, if gammaemitting radionuclides are present, the gamma dose rate will be attenuated or reduced as a result of the increased density of the vitrification matrix.

If the new treatment standards proposed by EPA for toxic metals (Proposed Rules, Federal Register, Vol. 58, No. 176, September 14, 1993) are implemented, the Toxicity Characteristic Leaching Procedure (TCLP) concentration limit for chromium will decrease by a factor of 15 , from the current $5.0 \mathrm{mg} / \mathrm{l}$ to $0.33 \mathrm{mg} / 1$ for non-wastewater. Cemented wastes may not meet this limit, but tests using wastewater treatment sludges and ion exchange resins have shown that vitrified waste should meet this limit (J. B. Mason, "Modular Enviroglass" Technology for Low-Level Radioactive and Mixed Wastes," VECTRA Document No. SP-501001, Rev. 2, VECTRA Technologies, Inc., Richland, WA.).

\section{C4.6 Encapsulation}

Encapsulation is primarily applicable to solid waste containing hazardous metal constituents, such as discarded circuit boards or instrumentation. The waste is shredded, dried, mixed with an organic polymer (e.g., polyethylene), thermosetting resin, or asphalt at $120-130^{\circ} \mathrm{C}$, and allowed to cure into a solid mass prior to disposal. As with all waste immobilization processes, the goal is to minimize leaching after disposal. This process is not suitable for wastes that decompose at these temperatures or that contain strong oxidizers such as nitrites, chlorates, or perchlorates that can react with the binder material.

TFM\&C waste streams for which encapsulation is the proposed treatment include batteries for which recycling is impractical, instrumentation, and shielding lead, if it is to be used in the extraction area. Macroencapsulation (encapsulating an entire mass, rather than microencapsulation, which coats individual particles of a waste) is the Best Demonstrated Available Technology (BDAT) for radioactive lead solids.

\section{C4.7 Metals Recovery}

Stainless steel waste generated by TFM\&C facilities can be recovered and recycled by melting in a rotary kiln or plasma arc furnace under a reducing atmosphere. There is insufficient waste to justify a metal recycling facility just for TFM\&C waste. But opportunity exists for participating in metal recycling facilities underway, as described below.

The DOE Office of Technology Development is funding SRS to conduct a demonstration of the beneficial reuse of stainless recycled radioactive scrap metal. Thousands of tons of stainless steel from obsolete reactor heat exchangers with slight tritium contamination may potentially be recycled. B-25 stainless steel containers cast from recycled metal have been made for use at Oak Ridge to support the Transportable Vitrification System. In South Carolina, metal recycling and container fabrication has been contracted to Carolina Metals, Inc., in Barnwell, SC. 
Retech Inc. (Ukiah, CA) has signed a cooperative research and development agreement with INEL to develop melting technologies that will allow reuse of radioactivity contaminated metals. Using its plasma arc centrifugal furnace technology, Retech will melt stainless steel containing surrogates for radioactive constituents and evaluate the fate of the surrogates during the process of melting, pouring and cooling the test metal. 
Tritium Facilities Modernization \& Consolidation Project Process Waste Assessment
WSRC-TR-97-00368, Rev.0

November 14,1997

[This Page is Intentionally Left Blank] 


\section{APPENDIX D}

\section{Waste Stream Inventory by Waste Type}

Appendix D lists the masses $(\mathrm{kg})$, volumes $\left(\mathrm{m}^{3}\right)$, and average bulk density $\left(\mathrm{kg} / \mathrm{m}^{3}\right)$ by waste type (low-level radioactive waste, mixed low-level waste, hazardous waste, and radioactive liquid waste) for each waste stream discussed in Appendix B. Intermediate-level waste streams are listed under low-level radioactive waste. Some waste streams are included even though projected quantities are determined to be none at this time. Due to round-off of masses and volumes, several average bulk densities vary slightly that should otherwise be the same (e.g., all job control waste streams should have the same average bulk density). 
Tritium Facilities Modernization \& Consolidation Project Process Waste Assessment
WSRC-TR-97-00368, Rev.0

November 14, 1997

TFM \& C Process Low-Level Radioactive Waste Streams

\begin{tabular}{|c|l|r|r|r|}
\hline $\begin{array}{c}\text { Waste Stream } \\
\text { Number }\end{array}$ & \multicolumn{1}{|c|}{$\begin{array}{c}\text { Waste Stream } \\
\text { Description }\end{array}$} & $\begin{array}{c}\text { Mass } \\
\mathbf{k g} / \mathbf{y r}\end{array}$ & $\begin{array}{c}\text { Volume } \\
\mathbf{m}^{\mathbf{3}} / \mathbf{y r}\end{array}$ & $\begin{array}{c}\text { Bulk Density } \\
\mathbf{k g} / \mathbf{m}^{\mathbf{3}}\end{array}$ \\
\hline B1 & Job Control Waste (H-3) & 5,068 & 33.6 & 1511 \\
\hline B3 & Non-hazardous Equipment (H-3) & 3,410 & 2.6 & 1,312 \\
\hline B4 & Mg/U Beds* & 855 & 2.8 & 305 \\
\hline B5 & $\begin{array}{c}\text { Hydride/Getter/Catalyst/Zeolite } \\
\text { Beds }\end{array}$ & 103 & 0.147 & 700 \\
\hline B9 & Non-hazardous Tritiated Oil & 180 & 0.2 & 900 \\
\hline B9a & Glove-box Bubbler Fluid & 5.4 & 0.006 & 900 \\
\hline B12 & Palladium/Electrolysis Membrane & 0 & 0 & - \\
\hline \hline & Total & $9,621.4$ & 39.353 & 244 \\
\hline
\end{tabular}

*TFM\&C Z-Bed Recovery system will use Mg beds.

TFM \& C Process Mired Low-level Waste Streams

\begin{tabular}{|c|l|r|r|r|}
\hline $\begin{array}{c}\text { Waste Stream } \\
\text { Number }\end{array}$ & \multicolumn{1}{|c|}{$\begin{array}{c}\text { Waste Stream } \\
\text { Description }\end{array}$} & $\begin{array}{c}\text { Mass } \\
\mathbf{k g} / \mathbf{y r}\end{array}$ & $\begin{array}{c}\text { Volume } \\
\mathbf{m}^{\mathbf{3} / \mathbf{y r}}\end{array}$ & $\begin{array}{c}\text { Bulk Density } \\
\mathbf{k g} / \mathrm{m}^{\mathbf{3}}\end{array}$ \\
\hline B2 & Job Control Waste (Mixed) & $\mathbf{7 6 0}$ & $\mathbf{5 . 0}$ & 152 \\
\hline B2a & Mixed Waste Solvent Rags & 0 & 0 & - \\
\hline B6 & $\begin{array}{c}\text { Mixed Waste Process } \\
\text { Equipment* }\end{array}$ & $(23)$ & $(0.01)$ & $(2300)$ \\
\hline B6a & Teledyne Micro-fuel Cells & 1.4 & 0.001 & 1,400 \\
\hline B7 & $\begin{array}{c}\text { Mixed and Hazardous Waste } \\
\text { Oil/Solvent }\end{array}$ & 0 & 0 & - \\
\hline B8 & Analytical/Rad Con Chemicals & $* *$ & $* \star$ & - \\
\hline B11 & Mixed Waste Mercury & 0 & 0 & - \\
\hline & Total & 761.4 & 5.001 & 152 \\
\hline
\end{tabular}

* Palladium-silver diffusers have not been definitively classified as mixed waste. Thus, the waste mass and volume are not included in the totals.

**Assume most chemicals will be disposed as hazardous waste. As mixed waste, they are covered in the other mixed waste streams: B2a, and B7. 
TFM \& C Process Hazardous Waste Streams

\begin{tabular}{|c|l|r|r|r|}
\hline $\begin{array}{c}\text { Waste Stream } \\
\text { Number }\end{array}$ & \multicolumn{1}{|c|}{$\begin{array}{c}\text { Waste Stream } \\
\text { Description }\end{array}$} & $\begin{array}{c}\text { Mass } \\
\mathbf{k g} / \mathbf{y r}\end{array}$ & $\begin{array}{c}\text { Volume } \\
\mathbf{m}^{\mathbf{3}} / \mathbf{y r}\end{array}$ & $\begin{array}{c}\text { Bulk Density } \\
\mathbf{k g} / \mathbf{m}^{\mathbf{3}}\end{array}$ \\
\hline B6a & Teledyne Micro-fuel Cells & 0.9 & 0.001 & 900 \\
\hline B7 & $\begin{array}{l}\text { Mixed and Hazardous Waste } \\
\text { Oil/Solvent }\end{array}$ & 0 & $\mathbf{0}$ & - \\
\hline B8 & Analytical/Rad Con Chemicals & 293 & $\mathbf{0 . 3}$ & 977 \\
\hline & Total & 294 & $\mathbf{0 . 3 0 1}$ & 977 \\
\hline
\end{tabular}

TFM \& C Process Radioactive Liquid Waste Streams

\begin{tabular}{|c|l|c|c|c|}
\hline $\begin{array}{c}\text { Waste Stream } \\
\text { Number }\end{array}$ & \multicolumn{1}{|c|}{$\begin{array}{c}\text { Waste Stream } \\
\text { Description }\end{array}$} & $\begin{array}{c}\text { Mass } \\
\mathbf{k g} / \mathbf{y r}\end{array}$ & $\begin{array}{c}\text { Volume } \\
\mathbf{m}^{\mathbf{3}} / \mathbf{y r}\end{array}$ & $\begin{array}{c}\text { Bulk Density } \\
\mathbf{k g} / \mathbf{m}^{\mathbf{3}}\end{array}$ \\
\hline B7 & $\begin{array}{c}\text { Mixed and Hazardous Waste } \\
\text { Oil/Solvents }\end{array}$ & 0 & 0 & - \\
\hline B9 & Non-hazardous Tritiated Oil & 90 & $\mathbf{0 . 1}$ & 900 \\
\hline & Total & 90 & $\mathbf{0 . 1}$ & 900 \\
\hline
\end{tabular}


Tritium Facilities Modernization \& Consolidation Project

Process Waste Assessment
WSRC-TR-97-00368, Rev.0

November 14, 1997

[This Page Intentionally Left Blank]

D- 4 
Tritium Facilities Modernization \& Consolidation Project

WSRC-RP-97-00368, Rev. 0

Process Waste Assessment

November 14, 1997

\section{APPENDIX E}

\section{Waste Stream Inventory by Waste Treatment Category}

Appendix $\mathrm{E}$ lists the masses $(\mathrm{kg})$, volumes $\left(\mathrm{m}^{3}\right)$ and bulk densities $\left(\mathrm{kg} / \mathrm{m}^{3}\right)$ for each low-level radioactive waste, mixed low-level waste and hazardous waste stream by waste treatment category and disposal option. Several waste streams have multiple treatment/disposal options available, based on waste form and radionuclide content. These options are discussed in detail for each waste stream in Appendix B. 
Tritium Facilities Modernization \& Consolidation Project

WSRC-RP-97-00368, Rev. 0

Process Waste Assessment

November 14, 1997

Incineration and Stabilization of Residue

A. Low-Level Radioactive Waste

\begin{tabular}{|c|l|c|c|c|}
\hline $\begin{array}{c}\text { Waste Stream } \\
\text { Number }\end{array}$ & \multicolumn{1}{|c|}{$\begin{array}{c}\text { Waste Stream } \\
\text { Description }\end{array}$} & $\begin{array}{c}\text { Mass } \\
\mathbf{k g} / \mathbf{y r}\end{array}$ & $\begin{array}{c}\text { Volume } \\
\mathbf{m}^{\mathbf{3}} / \mathbf{y r}\end{array}$ & $\begin{array}{c}\text { Bulk } \\
\text { Density } \\
\mathbf{~}\end{array}$ \\
\hline B1 & Job Control Waste (H-3) & 3,800 & 25.2 & 149 \\
\hline B9 & Non-hazardous Tritiated Oil & 90 & 0.1 & 900 \\
\hline B9a & Glovebox Bubbler Fluid & 1.8 & 0.002 & 900 \\
\hline Total & & $3,891.8$ & 25.3 & 154 \\
\hline
\end{tabular}

B. Mixed Low-level Waste

\begin{tabular}{|c|c|c|c|c|}
\hline $\begin{array}{c}\text { Waste Stream } \\
\text { Number }\end{array}$ & $\begin{array}{c}\text { Waste Stream } \\
\text { Description }\end{array}$ & $\begin{array}{c}\text { Mass } \\
\mathbf{k g} / \mathbf{y r}\end{array}$ & $\begin{array}{c}\text { Volume } \\
\mathbf{m}^{\mathbf{3}} / \mathbf{y r}\end{array}$ & $\begin{array}{c}\text { Bulk } \\
\text { Density } \\
\mathbf{k g} / \mathbf{m}^{3}\end{array}$ \\
\hline B2 & Job Control Waste (Mixed) & 380 & 2.5 & 152 \\
\hline Total & & 380 & 2.5 & 152 \\
\hline
\end{tabular}

C. Hazardous Waste

\begin{tabular}{|c|l|c|c|c|}
\hline $\begin{array}{c}\text { Waste Stream } \\
\text { Number }\end{array}$ & \multicolumn{1}{|c|}{$\begin{array}{c}\text { Waste Stream } \\
\text { Description }\end{array}$} & $\begin{array}{c}\text { Mass } \\
\mathbf{k g} / \mathbf{y r}\end{array}$ & $\begin{array}{c}\text { Volume } \\
\mathbf{m}^{\mathbf{3}} / \mathbf{y r}\end{array}$ & $\begin{array}{c}\text { Bulk } \\
\text { Density } \\
\mathbf{k g} / \mathbf{m}^{\mathbf{3}}\end{array}$ \\
\hline B7 & Mixed/Hazardous Oil & - & - & - \\
\hline B8 & $\begin{array}{l}\text { Analytical Lab/Rad Con } \\
\text { Chemicals* }\end{array}$ & 82 & 0.091 & 900 \\
\hline Total & & 82 & 0.091 & 900 \\
\hline
\end{tabular}

*Includes approximately $180 \mathrm{lb}$. (82 kg) of pump oil from Appendix B Waste Stream B9 inventory list. A Specific Gravity of $0.9\left(900 \mathrm{~kg} / \mathrm{m}^{3}\right)$ for oil is assumed. 
Tritium Facilities Modernization \& Consolidation Project

Process Waste Assessment

WSRC-RP-97-00368, Rev. 0

November 14, 1997

\section{Compaction for EAV LAW Vault Disposal}

A. Low-Level Radioactive Waste

\begin{tabular}{|c|c|c|c|c|}
\hline $\begin{array}{c}\text { Waste Stream } \\
\text { Number }\end{array}$ & $\begin{array}{c}\text { Waste Stream } \\
\text { Description }\end{array}$ & $\begin{array}{c}\text { Mass } \\
\mathbf{k g} / \mathbf{y r}\end{array}$ & $\begin{array}{c}\text { Volume } \\
\mathbf{m}^{\mathbf{3}} / \mathrm{yr}\end{array}$ & $\begin{array}{c}\text { Bulk } \\
\text { Density } \\
\mathbf{k g} / \mathrm{m}^{3}\end{array}$ \\
\hline B1 & Job Control Waste (H-3) & 634 & 4.2 & 151 \\
\hline Total & & 634 & 4.2 & 151 \\
\hline
\end{tabular}

Direct Disposal to LAW Vaults

A. Low-Level Radioactive Waste

\begin{tabular}{|c|l|c|c|c|}
\hline $\begin{array}{c}\text { Waste Stream } \\
\text { Number }\end{array}$ & \multicolumn{1}{|c|}{$\begin{array}{c}\text { Waste Stream } \\
\text { Description }\end{array}$} & $\begin{array}{c}\text { Mass } \\
\mathbf{k g} / \mathbf{y r}\end{array}$ & $\begin{array}{c}\text { Volume } \\
\mathbf{m}^{3} / \mathbf{y r}\end{array}$ & $\begin{array}{c}\text { Bulk } \\
\text { Density } \\
\mathbf{k g} / \mathbf{m}^{3}\end{array}$ \\
\hline B1 & Job Control Waste (H-3) & 634 & 4.2 & 151 \\
\hline B3 & Equipment (H-3) & 1,705 & 1.3 & 1,312 \\
\hline B5 & $\begin{array}{l}\text { Hydride/Getter/Catalyst/ } \\
\text { Zeolite Beds }\end{array}$ & 103 & 0.147 & 700 \\
\hline B9 & Non-hazardous Tritiated Oil* & 180 & 0.2 & 900 \\
\hline B9a & Glovebox Bubbler Fluid* & 3.6 & 0.004 & 900 \\
\hline Total & & $2,625.6$ & 5.85 & 449 \\
\hline
\end{tabular}

*These liquids are stabilized before disposal.

\section{Direct Disposal to ILTV Bulk Cell}

A. Low-Level Radioactive Waste (Intermediate Level Waste)

\begin{tabular}{|c|l|c|c|c|}
\hline $\begin{array}{c}\text { Waste Stream } \\
\text { Number }\end{array}$ & \multicolumn{1}{|c|}{$\begin{array}{c}\text { Waste Stream } \\
\text { Description }\end{array}$} & $\begin{array}{c}\text { Mass } \\
\mathbf{k g} / \mathbf{y r}\end{array}$ & $\begin{array}{c}\text { Volume } \\
\mathbf{m}^{3} / \mathbf{y r}\end{array}$ & $\begin{array}{c}\text { Bulk } \\
\text { Density } \\
\mathbf{~ k g} / \mathbf{m}^{3}\end{array}$ \\
\hline B3 & Equipment (H-3) & 1,705 & 1.3 & 1,312 \\
\hline B4 & Mg/U Beds & 855 & 2.8 & 305 \\
\hline Total & & 2,560 & 4.1 & 624 \\
\hline
\end{tabular}




\section{Interim Storage/Off-site Disposal}

B. Mired Low-Level Waste

\begin{tabular}{|c|l|c|c|c|}
\hline $\begin{array}{c}\text { Waste Stream } \\
\text { Number }\end{array}$ & \multicolumn{1}{|c|}{$\begin{array}{c}\text { Waste Stream } \\
\text { Description }\end{array}$} & $\begin{array}{c}\text { Mass } \\
\mathbf{k g} / \mathbf{y r}\end{array}$ & $\begin{array}{c}\text { Volume } \\
\mathbf{m}^{3} / \mathbf{y r}\end{array}$ & $\begin{array}{c}\text { Bulk } \\
\text { Density } \\
\mathbf{k g} / \mathrm{m}^{3}\end{array}$ \\
\hline B2 & Job Control Waste (Mixed) & 380 & 2.5 & 152 \\
\hline B6 & Mixed Waste Equipment & 23 & 0.01 & 2,300 \\
\hline B6a & $\begin{array}{l}\text { Oxygen Sensor Micro-fuel } \\
\text { Cells }\end{array}$ & 1.4 & 0.001 & 1,400 \\
\hline Total & & 404.4 & 2.511 & 161 \\
\hline
\end{tabular}

\section{Hazardous Waste}

\begin{tabular}{|c|l|c|c|c|}
\hline $\begin{array}{c}\text { Waste Stream } \\
\text { Number }\end{array}$ & \multicolumn{1}{|c|}{$\begin{array}{c}\text { Waste Stream } \\
\text { Description }\end{array}$} & $\begin{array}{c}\text { Mass } \\
\mathbf{k g} / \mathbf{y r}\end{array}$ & $\begin{array}{c}\text { Volume } \\
\mathbf{m}^{\mathbf{3}} / \mathbf{y r}\end{array}$ & $\begin{array}{c}\text { Bulk } \\
\text { Density } \\
\mathbf{k g} / \mathbf{m}^{3}\end{array}$ \\
\hline B6a & $\begin{array}{l}\text { Oxygen Sensor Micro-fuel } \\
\text { Cells }\end{array}$ & 0.9 & 0.001 & 900 \\
\hline B8 & $\begin{array}{l}\text { Analytical Lab/Rad Con } \\
\text { Chemicals* }\end{array}$ & 211 & 0.211 & 1000 \\
\hline Total & & 211.9 & 0.212 & 1000 \\
\hline
\end{tabular}

*Analytical Laboratory/Rad Con chemicals are wastes for which treatments cannot a priori be defined. Treatment will be a function of the type of chemical; e.g., solid, liquid, acid, base, etc. Most chemicals are assumed to be clean non-radioactive waste and can be shipped to an off-site vendor for processing. The number shown here is approxinnate, excluding Opti-Fluor, pump oils and alcohols. A specific gravity of 1.0 is assumed. 


\section{APPENDIX F}

\section{EPA Hazardous Waste Codes With Subcategories}

Table F1 below lists EPA hazardous waste codes for which EPA has developed sub-categories (40 CFR sections 268.41 through 268.43, Tables CCWE, 2, 3, and CCW). For each sub-category, DOE has assigned a letter subcode. The sub-categories represent unique Land Disposal Restrictions (LDR) treatability groups with distinct treatment standards. In addition, DOE has assigned a sub-category (with subcode " $X$ ") for wastes that, because of a lack of characterization information, could not be put into an appropriate EPA defined sub-category. This table was developed in support of the SRS Approved Site Treatment Plan for mixed waste, WSRC-TR-940608, and may be subject to change. 
Table F1

EPA Hazardous Waste Codes with Sub-categories defined under the LDRs Program

\begin{tabular}{|c|c|c|c|c|}
\hline $\begin{array}{l}\text { EPA } \\
\text { Code }\end{array}$ & $\begin{array}{l}\text { Sub } \\
\text { code }\end{array}$ & Subcategory & $\begin{array}{l}\text { Conc } \\
\text { Limit }\end{array}$ & Description \\
\hline \multirow[t]{3}{*}{$\mathrm{D} 001$} & $\mathbf{A}$ & $\begin{array}{l}\text { Ignitable Liquids High TOC } \\
\text { Nonwastewaters }\end{array}$ & & $\begin{array}{l}\text { Ignitable liquids as defined in } 40 \\
\text { CFR } 261.21 \text { containing } 10 \% \text { or } \\
\text { greater Total Organic Carbon } \\
\text { (TOC). }\end{array}$ \\
\hline & B & Ignitable Liquids, Wastewaters & & $\begin{array}{l}\text { Ignitable wastes as identified in } 40 \\
\text { CFR } 261.21 \text { managed as } \\
\text { wastewater [e.g., in Clean Water } \\
\text { Act surface impoundments or land } \\
\text { disposal units (or their equivalent); } \\
\text { or in Safe Drinking Water Act } \\
\text { underground injection wells]. }\end{array}$ \\
\hline & $\mathrm{C}$ & $\begin{array}{l}\text { Ignitable Waste, Low TOC } \\
\text { Nonwastewaters }\end{array}$ & & $\begin{array}{l}\text { All other ignitable waste as } \\
\text { identified in } 40 \text { CFR } 261.21 \text { that is } \\
\text { neither a high TOC nor managed as } \\
\text { wastewater. }\end{array}$ \\
\hline \multirow[t]{3}{*}{$\mathrm{D} 002$} & $\bar{A}$ & $\begin{array}{l}\text { Corrosive Wastewater-Acid, } \\
\text { Alkaline or Other }\end{array}$ & & $\begin{array}{l}\text { Corrosive waste, as identified in } 40 \\
\text { CFR 261.22, managed as } \\
\text { wastewater. [e.g., in Clean Water } \\
\text { Act surface impoundments or land } \\
\text { disposed units (or their equivalent); } \\
\text { or in Safe Drinking Water Act } \\
\text { underground injection wells.] }\end{array}$ \\
\hline & $\bar{B}$ & $\begin{array}{l}\text { Corrosive Nonwastewater- } \\
\text { Acid, Alkaline or Other }\end{array}$ & & $\begin{array}{l}\text { Corrosive waste, as identified in } 40 \\
\text { CFR 261.22, not managed as } \\
\text { wastewater. }\end{array}$ \\
\hline & $\mathbf{C}$ & High-Level Wastes & & $\begin{array}{l}\text { Wastes that exhibit the properties } \\
\text { listed in } 40 \mathrm{CFR} 261.22(\mathrm{a})(1) \text { and } \\
\text { are radioactive high-level wastes } \\
\text { generated during the reprocessing } \\
\text { of nuclear fuel rods. }\end{array}$ \\
\hline
\end{tabular}


Table F1

EPA Hazardous Waste Codes with Sub-categories defined under the LDRs Program (Cont'd)

\begin{tabular}{|c|c|c|c|c|}
\hline $\begin{array}{l}\text { EPA } \\
\text { Code }\end{array}$ & $\begin{array}{l}\text { Sub } \\
\text { code }\end{array}$ & Sub-category & $\begin{array}{l}\text { Conc } \\
\text { Limit }\end{array}$ & Description \\
\hline \multirow[t]{5}{*}{ D003 } & $\mathbf{A}$ & Reactive Cyanides & & $\begin{array}{l}\text { Cyanide-bearing wastes that, when } \\
\text { exposed to pH conditions between } \\
2 \text { and } 12.5 \text {, generate hazardous } \\
\text { quantities of toxic gases. }\end{array}$ \\
\hline & B & Reactive Sulfides & & $\begin{array}{l}\text { Sulfide-bearing wastes that, when } \\
\text { exposed to pH conditions between } \\
2 \text { and } 12.5 \text {, generate hazardous } \\
\text { quantities of toxic gases. }\end{array}$ \\
\hline & $\bar{C}$ & Explosives & & $\begin{array}{l}\text { Waste capable of detonation or } \\
\text { explosive reaction under various } \\
\text { conditions, or is a forbidden, Class } \\
\text { A or Class B explosive under DOT } \\
\text { regulations. }\end{array}$ \\
\hline & $\mathbf{D}$ & Water Reactives & & $\begin{array}{l}\text { Waste, as defined in } 40 \text { CFR } \\
261.23(a)(2) \text {, (3), or ( } 4) \text {, that is } \\
\text { either very reactive with water, or } \\
\text { is capable of generating toxic or } \\
\text { explosive gases with water. }\end{array}$ \\
\hline & $\overline{\mathbf{E}}$ & Other Reactives & & $\begin{array}{l}\text { Reactive waste that, per } 40 \text { CFR } \\
261.23(a)(1) \text {, is normally unstable } \\
\text { and readily under goes violent } \\
\text { change without detonating. }\end{array}$ \\
\hline \multirow[t]{2}{*}{ D004 } & $\mathbf{A}$ & TCLP Toxic for Arsenic & $5.0 \mathrm{mg} / 1$ & $\begin{array}{l}\text { Those wastes that exhibit the } \\
\text { toxicity characteristics for arsenic. }\end{array}$ \\
\hline & $\mathbf{B}$ & As High-Level Wastes & & $\begin{array}{l}\text { Those wastes that exhibit the } \\
\text { toxicity characteristics for arsenic } \\
\text { and are radioactive high-level } \\
\text { wastes generated during the } \\
\text { reprocessing of nuclear fuel rods. }\end{array}$ \\
\hline \multirow[t]{2}{*}{$\mathrm{D} 005$} & $\overline{\mathbf{A}}$ & TCLP Toxic for Barium & $100 \mathrm{mg} / \mathrm{l}$ & $\begin{array}{l}\text { Those wastes that exhibit the } \\
\text { toxicity characteristics for barium. }\end{array}$ \\
\hline & $\mathbf{B}$ & Ba High-Level Wastes & & $\begin{array}{l}\text { Those wastes that exhibit the } \\
\text { toxicity characteristics for barium } \\
\text { and are radioactive high-level } \\
\text { wastes generated during the } \\
\text { reprocessing of nuclear fuel rods. }\end{array}$ \\
\hline D006 & $\mathbf{A}$ & TCLP Toxic for Cadmium & $1.0 \mathrm{mg} / 1$ & $\begin{array}{l}\text { Those wastes that exhibit the } \\
\text { toxicity characteristic for cadmium. }\end{array}$ \\
\hline
\end{tabular}




\section{Table F1}

EPA Hazardous Waste Codes with Sub-categories defined under the LDRs Program (Cont'd)

\begin{tabular}{|c|c|c|c|c|}
\hline $\begin{array}{l}\text { EPA } \\
\text { Code }\end{array}$ & $\begin{array}{l}\text { Sub } \\
\text { code }\end{array}$ & Sub-category & $\begin{array}{l}\text { Conc } \\
\text { Limit }\end{array}$ & Description \\
\hline \multirow[t]{2}{*}{ D006 } & $\overline{\mathbf{B}}$ & Cadmium containing batteries & & $\begin{array}{l}\text { Batteries containing leachable levels } \\
\text { of cadmium above } 1.0 \mathrm{mg} / \mathrm{liter} \text {. }\end{array}$ \\
\hline & C & Cd High-Level Wastes & & $\begin{array}{l}\text { Those wastes that exhibit the toxicity } \\
\text { characteristics for cadmium and are } \\
\text { radioactive high-level wastes } \\
\text { generated during the reprocessing of } \\
\text { nuclear fuel rods. }\end{array}$ \\
\hline \multirow[t]{2}{*}{ D007 } & $\overline{\mathbf{A}}$ & TCLP Toxic for Chromium & $5.0 \mathrm{mg} / \mathrm{l}$ & $\begin{array}{l}\text { Those wastes that exhibit the toxicity } \\
\text { characteristic for cadmium. }\end{array}$ \\
\hline & $\bar{B}$ & Cr High-Luvel Wastes & & $\begin{array}{l}\text { Those wastes that exhibit the toxicity } \\
\text { characteristics for chromium and are } \\
\text { radioactive high-level wastes } \\
\text { generated during the reprocessing of } \\
\text { nuclear fuel rods. }\end{array}$ \\
\hline \multirow[t]{4}{*}{ D008 } & $\overline{\mathbf{A}}$ & TCLP Toxic for Lead & $5.0 \mathrm{mg} / 1$ & $\begin{array}{l}\text { Those wastes that exhibit the toxicity } \\
\text { characteristic for lead. }\end{array}$ \\
\hline & B & Lead Acid Batteries & & $\begin{array}{l}\text { Lead acid batteries that are identified } \\
\text { as RCRA hazardous wastes and which } \\
\text { are not excluded from regulation } \\
\text { under the land disposal restrictions. }\end{array}$ \\
\hline & $\bar{C}$ & Radioactive Lead Solids & & $\begin{array}{l}\text { Lead solids, including elemental } \\
\text { forms of lead, but not including } \\
\text { treatment residuals that can be } \\
\text { stabilized or organo-lead materials } \\
\text { that can be incinerated (then } \\
\text { stabilized as ash). }\end{array}$ \\
\hline & D & Pb High-Level Wastes & & $\begin{array}{l}\text { Those wastes that exhibit the toxicity } \\
\text { characteristics for lead and are } \\
\text { radioactive high-level wastes } \\
\text { generated during the reprocessing of } \\
\text { nuclear fuel rods. }\end{array}$ \\
\hline \multirow[t]{2}{*}{ D009 } & $\bar{A}$ & TCLP Toxic for Mercury & $0.2 \mathrm{mg} / \mathrm{l}$ & $\begin{array}{l}\text { Nonwastewaters that exhibit the } \\
\text { toxicity characteristic for mercury and } \\
\text { contain less than } 260 \mathrm{mg} / \mathrm{kg} \text { total } \\
\text { mercury. }\end{array}$ \\
\hline & $\mathbf{B}$ & $\begin{array}{l}\text { High Mercury (Contains } \\
\text { Organics) }\end{array}$ & & $\begin{array}{l}\text { Nonwastewaters that exhibit the } \\
\text { toxicity characteristic for mercury, } \\
\text { contain greater than or equal to } 260 \\
\text { mg/kg total mercury, also contain } \\
\text { organics, and are not incinerator } \\
\text { residues. }\end{array}$ \\
\hline
\end{tabular}


Table F1

EPA Hazardous Waste Codes with Sub-categories defined under the LDRs Program (Cont'd)

\begin{tabular}{|c|c|c|c|c|}
\hline $\begin{array}{l}\text { EPA } \\
\text { Code } \\
\end{array}$ & $\begin{array}{l}\text { Sub } \\
\text { code }\end{array}$ & Sub-category & $\begin{array}{l}\text { Conc } \\
\text { Limit }\end{array}$ & Description \\
\hline \multirow[t]{5}{*}{ D009 } & $\mathbf{C}$ & $\begin{array}{l}\text { High Mercury (Contains } \\
\text { Inorganics) }\end{array}$ & & $\begin{array}{l}\text { Non-wastewaters that exhibit the } \\
\text { toxicity characteristic for mercury, } \\
\text { contain greater than or equal to } 260 \\
\text { mg/kg total mercury, are inorganic, } \\
\text { and may include incinerator } \\
\text { residues and residues from mercury } \\
\text { roasting and retorting (RMERC) } \\
\text { operations. }\end{array}$ \\
\hline & $\bar{D}$ & $\begin{array}{l}\text { Elemental Mercury } \\
\text { Contaminated with Radioactive } \\
\text { Materials }\end{array}$ & & $\begin{array}{l}\text { Elemental mercury contaminated } \\
\text { with radioactive materials. }\end{array}$ \\
\hline & $\mathbf{E}$ & $\begin{array}{l}\text { Hydraulic Oil Contaminated } \\
\text { with Mercury Radioactive } \\
\text { Materials }\end{array}$ & & $\begin{array}{l}\text { Hydraulic oil exhibiting the toxicity } \\
\text { characteristic for mercury and } \\
\text { which is contaminated with } \\
\text { radioactive materials. }\end{array}$ \\
\hline & $\mathbf{F}$ & Mercury Wastewaters & & $\begin{array}{l}\text { All D009 waste managed as } \\
\text { wastewater. }\end{array}$ \\
\hline & $\mathbf{X}$ & $\begin{array}{l}\text { Nonwastewater with Unknown } \\
\text { Mercury Concentration }\end{array}$ & & $\begin{array}{l}\text { Characteristically hazardous mixed } \\
\text { wastes due to mercury that are not } \\
\text { elementary mercury, hydraulic oil } \\
\text { or high-level waste, for which it is } \\
\text { not known if the mercury } \\
\text { concentration is less than or equal } \\
\text { to } 260 \text { ppm. }\end{array}$ \\
\hline \multirow[t]{2}{*}{ D010 } & $\mathbf{A}$ & TCLP Toxic for Selenium & $5.7 \mathrm{mg} / 1$ & $\begin{array}{l}\text { Those wastes that exhibit the } \\
\text { toxicity characteristics for } \\
\text { selenium. }\end{array}$ \\
\hline & $\overline{\mathbf{B}}$ & Se High-Level Wastes & & $\begin{array}{l}\text { Those wastes that exhibit the } \\
\text { toxicity characteristics for selenium } \\
\text { and are radioactive high-level } \\
\text { wastes generated during the } \\
\text { reprocessing of nuclear fuel rods. }\end{array}$ \\
\hline \multirow[t]{2}{*}{ D011 } & $\mathbf{A}$ & TCLP Toxic for Silver & $5.0 \mathrm{mg} / \mathrm{l}$ & $\begin{array}{l}\text { Those wastes that exhibit the } \\
\text { toxicity characteristics for silver. }\end{array}$ \\
\hline & $\mathbf{B}$ & Ag High-Level Wastes & & $\begin{array}{l}\text { Those wastes that exhibit the } \\
\text { toxicity characteristics for silver } \\
\text { and are radioactive high-level } \\
\text { wastes generated during the } \\
\text { reprocessing of nuclear fuel rods. }\end{array}$ \\
\hline
\end{tabular}


Table F1

EPA Hazardous Waste Codes with Sub-categories defined under the LDRs Program (Cont'd)

\begin{tabular}{|c|c|c|c|c|}
\hline $\begin{array}{l}\text { EPA } \\
\text { Code } \\
\end{array}$ & $\begin{array}{l}\text { Sub } \\
\text { code }\end{array}$ & Sub-category & $\begin{array}{l}\text { Conc } \\
\text { Limit } \\
\end{array}$ & Description \\
\hline \multirow[t]{2}{*}{ F003 } & $\mathbf{A}$ & $\begin{array}{l}\text { Spent Non-halogenated } \\
\text { Solvents }\end{array}$ & $\begin{array}{c}2.6-180 \\
\mathrm{mg} / 1\end{array}$ & $\begin{array}{l}\text { F003 solvent due to the presence of } \\
\text { one of the following: acetone, ethyl } \\
\text { acetate, ethyl benzene, ethyl ether, } \\
\text { methyl isobutyl ketone, n-Butyl } \\
\text { alcohol, and xylene. Also } \\
\text { cyclohexane, but only if F001-F005 } \\
\text { solvents other than methanol and/or } \\
\text { carbon disulfide (F005) are also } \\
\text { present. Also methanol, but only if } \\
\text { F001-F005 solvents other than } \\
\text { cyclohexane and/or carbon disulfide } \\
\text { (F005) are also present. }\end{array}$ \\
\hline & B & $\begin{array}{l}\text { Cyclohexiane/Methanol/Carbon } \\
\text { Disulfide Only }\end{array}$ & & $\begin{array}{l}\text { F003 solvent due to the presence of } \\
\text { cyclohexane, methanol or carbon } \\
\text { disulfide, but only if no other F001- } \\
\text { F005 solvents are present (except } \\
\text { cyclohexane, methanol and/or carbon } \\
\text { disulfide are also present). }\end{array}$ \\
\hline \multirow[t]{4}{*}{ F005 } & $\bar{A}$ & $\begin{array}{l}\text { Spent Non-halogenated } \\
\text { Solvents }\end{array}$ & $\begin{array}{c}10-170 \\
\mathrm{mg} / 1\end{array}$ & $\begin{array}{l}\text { The following spent non-halogenated } \\
\text { solvents: benzene, isobutanol, } \\
\text { methylethyl ketone, pyridine, and } \\
\text { toluene. Also, carbon disulfide if } \\
\text { F001-F005 solvents other than } \\
\text { cyclohexane (F003) and/or methanol } \\
\text { (F003) are also present. Also, 2- } \\
\text { Bthoxyethanol and 2-Nitropropane, } \\
\text { but only if other F001-F005 solvents } \\
\text { are also present. }\end{array}$ \\
\hline & $\mathbf{B}$ & $\begin{array}{l}\text { Solvent Waste Listed for 2- } \\
\text { Nitropropane only }\end{array}$ & & $\begin{array}{l}\text { Waste containing 2-nitropropane as } \\
\text { the only F001-F005 listed solvent. }\end{array}$ \\
\hline & $\mathrm{C}$ & $\begin{array}{l}\text { Solvent Waste Listed for 2- } \\
\text { Ethoxyethanol only }\end{array}$ & & $\begin{array}{l}\text { Waste containing 2-ethoxyethanol as } \\
\text { the only F001-F005 listed solvent. }\end{array}$ \\
\hline & D & $\begin{array}{l}\text { Cyclohexane/Methanol/Carbon } \\
\text { Disulfide only }\end{array}$ & & $\begin{array}{l}\text { F005 listed mixed waste for which the } \\
\text { specific F005 constituent is not } \\
\text { identified. } \\
\text { F005 solvent due to the presence of } \\
\text { carbon disulfide, but only if no other } \\
\text { F001-F005 solvents are present, } \\
\text { except that cyclohexane (F003) and/or } \\
\text { methanol (F003) may also be present. }\end{array}$ \\
\hline
\end{tabular}


Tritium Facilities Modernization \& Consolidation Project

WSRC-TR-97-00368, Rev.0

Process Waste Assessment

November 14,1997

Table F1

EPA Hazardous Waste Codes with Sub-categories defined under the LDRs Program (Cont'd)

\begin{tabular}{|c|c|c|c|c|}
\hline $\begin{array}{l}\text { EPA } \\
\text { Code }\end{array}$ & $\begin{array}{l}\text { Sub } \\
\text { code }\end{array}$ & Sub-category & $\begin{array}{l}\text { Conc } \\
\text { Limit }\end{array}$ & Description \\
\hline \multirow[t]{2}{*}{ F025 } & $\mathbf{A}$ & F025 Light Ends & & $\begin{array}{l}\text { Light ends listed for one or more of } \\
\text { the following: Carbon } \\
\text { Tetrachloride; chloroform; 1,2- } \\
\text { Dichloroethane; } 1,1 \text { - } \\
\text { Dichloroethylene; methylene } \\
\text { chloride; 1, 1, 2-Trichloroethane; } \\
\text { Trichloethane or vinyl chloride; } \\
\text { plus wastes qualifying as F025 } \\
\text { light ends, but characterization } \\
\text { information is insufficient to } \\
\text { determine specific contaminants. }\end{array}$ \\
\hline & $\overline{\mathbf{B}}$ & $\begin{array}{l}\text { Spent Filter/Aids and } \\
\text { Desiccants }\end{array}$ & & $\begin{array}{l}\text { Spent filters/aids containing one or } \\
\text { more of the following: Carbon } \\
\text { tetrachloride, chloroform, } \\
\text { methylene chloride, 1, 1, 2- } \\
\text { Trichloroethane, Trichloroethylene, } \\
\text { vinyl chloride, } \\
\text { hexachlorobutadiene, or } \\
\text { hexachloroethane, plus wastes } \\
\text { qualifying as F025 spent filters/aids } \\
\text { or desiccants, but characterization } \\
\text { is insufficient to determine specific } \\
\text { contaminants. }\end{array}$ \\
\hline \multirow[t]{2}{*}{ P047 } & $\overline{\mathbf{A}}$ & 4, 6-Dinitro-o-cresol & & $\begin{array}{l}\text { 4, 6-Dinitro-o-cresol as a discarded } \\
\text { commercial chemical product, off- } \\
\text { specification species, container } \\
\text { residue, or spill residue. }\end{array}$ \\
\hline & $\bar{B}$ & 4, 6-Dinitro-o-cresol salts & & $\begin{array}{l}\text { 4, 6-Dinitro-o-cresol salts as } \\
\text { discarded commercial chemical } \\
\text { products, off-specification species, } \\
\text { container residues, or spill residues. }\end{array}$ \\
\hline \multirow[t]{2}{*}{ P059 } & $\overline{\mathbf{A}}$ & Heptachlor & & $\begin{array}{l}\text { Heptachlor as a discarded } \\
\text { commercial chemical product, off- } \\
\text { specification species, container } \\
\text { residue, or spill residue. }\end{array}$ \\
\hline & B & Heptachlor Epoxide & & $\begin{array}{l}\text { Heptachlor epoxide as a discarded } \\
\text { commercial chemical product, off- } \\
\text { specification species, container } \\
\text { residue, or spill residue. }\end{array}$ \\
\hline
\end{tabular}


Table F1

EPA Hazardous Waste Codes with Sub-categories defined under the LDRs Program (Cont'd)

\begin{tabular}{|c|c|c|c|c|}
\hline $\begin{array}{l}\text { EPA } \\
\text { Code } \\
\end{array}$ & $\begin{array}{l}\text { Sub } \\
\text { code }\end{array}$ & Sub-category & $\begin{array}{l}\text { Conc } \\
\text { Limit } \\
\end{array}$ & Description \\
\hline \multirow[t]{5}{*}{ P065 } & $\mathbf{A}$ & $\begin{array}{l}\text { Mercury Fulminate - High } \\
\text { Mercury Incinerator or } \\
\text { RMERC Residues }\end{array}$ & & $\begin{array}{l}\text { Non-wastewaters with greater than or } \\
\text { equal to } 260 \mathrm{mg} / \mathrm{kg} \text { total mercury and } \\
\text { that are residues from either } \\
\text { incineration or mercury roasting or } \\
\text { retorting (RMERC) of wastes } \\
\text { containing mercury fulminate. }\end{array}$ \\
\hline & $\overline{\mathbf{B}}$ & $\begin{array}{l}\text { Mercury Fulminate Waste (not } \\
\text { from incineration or RMERC) }\end{array}$ & & $\begin{array}{l}\text { Non-wastewater mercury fulminate } \\
\text { waste, regardless of mercury content } \\
\text { that is neither residues from } \\
\text { incineration nor residues from } \\
\text { RMERC. }\end{array}$ \\
\hline & $\bar{C}$ & $\begin{array}{l}\text { Mercury Fulminate - Low } \\
\text { Mercury R'MERC Residues }\end{array}$ & & $\begin{array}{l}\text { Non-wastewaters with less than } 260 \\
\text { mg/kg total mercury and that are } \\
\text { residues from RMERC of wastes } \\
\text { containing mercury fulminate. }\end{array}$ \\
\hline & $\bar{D}$ & $\begin{array}{l}\text { Mercury Fulminate - Low } \\
\text { Mercury Incinerator Residues } \\
\text { (not RMERC) }\end{array}$ & & $\begin{array}{l}\text { Non-wastewaters with less than } 260 \\
\text { mg/kg total mercury and that are } \\
\text { residues from RMERC of wastes } \\
\text { containing mercury fulminate. }\end{array}$ \\
\hline & $\bar{E}$ & $\begin{array}{l}\text { Mercury Fulminate } \\
\text { Wastewaters }\end{array}$ & & $\begin{array}{l}\text { All P065 (mercury fulminate) waste } \\
\text { managed as wastewaters. }\end{array}$ \\
\hline \multirow[t]{3}{*}{ P092 } & $\overline{\mathbf{A}}$ & $\begin{array}{l}\text { Phenyl Meriury Acetate Non- } \\
\text { wastewater } \\
\text { High Mercury Incinerator or } \\
\text { RMERC Residues }\end{array}$ & & $\begin{array}{l}\text { Non-wastewaters phenyl mercury } \\
\text { acetate wastes, regardless of mercury } \\
\text { content, that are residues from either } \\
\text { incineration or mercury roasting or } \\
\text { retorting (RMERC) of wastes } \\
\text { containing phenyl mercury acetate. }\end{array}$ \\
\hline & B & $\begin{array}{l}\text { Phenyl Mercury Acetate } \\
\text { Non-wastewater } \\
\text { Phenyl Mercury Acetate Waste } \\
\text { (not from incineration or } \\
\text { RMERC) }\end{array}$ & & $\begin{array}{l}\text { Non-wastewaters phenyl mercury } \\
\text { acetate wastes, regardless of mercury } \\
\text { content, that are residues from } \\
\text { incineration nor residues from } \\
\text { RMERC. }\end{array}$ \\
\hline & C & $\begin{array}{l}\text { Phenyl Mercury Acetate } \\
\text { Non-wastewater } \\
\text { Low Mercury RMERC } \\
\text { Residues }\end{array}$ & & $\begin{array}{l}\text { Non-wastewaters with less than } 260 \\
\text { mg/kg total mercury and that are } \\
\text { residues from RMERC of wastes } \\
\text { containing phenyl mercury acetate. }\end{array}$ \\
\hline
\end{tabular}


Tritium Facilities Modernization \& Consolidation Project

Table F1

EPA Hazardous Waste Codes with Sub-categories defined under the LDRs Program (Cont'd)

\begin{tabular}{|c|c|c|c|c|}
\hline $\begin{array}{l}\text { EPA } \\
\text { Code }\end{array}$ & $\begin{array}{l}\text { Sub } \\
\text { code }\end{array}$ & Sub-category & $\begin{array}{l}\text { Conc } \\
\text { Limit }\end{array}$ & Description \\
\hline \multirow[t]{2}{*}{ P092 } & D & $\begin{array}{l}\text { Phenyl Mercury Acetate } \\
\text { Non-wastewaters } \\
\text { Low Mercury Incinerator } \\
\text { Residues (not RMERC) }\end{array}$ & & $\begin{array}{l}\text { Non-wastewaters with less than } \\
260 \mathrm{mg} / \mathrm{kg} \text { total mercury and that } \\
\text { are residues from incineration, but } \\
\text { not RMERC, of waste containing } \\
\text { phenyl mercury acetate. }\end{array}$ \\
\hline & $\overline{\mathbf{E}}$ & $\begin{array}{l}\text { Phenyl Mercury Acetate } \\
\text { Wastewaters }\end{array}$ & & $\begin{array}{l}\text { All P092 (mercury fulminate) } \\
\text { waste managed as wastewaters. }\end{array}$ \\
\hline \multirow[t]{5}{*}{$\mathrm{U} 151$} & $\overline{\mathbf{A}}$ & High Mercury Non-wastewater & & $\begin{array}{l}\text { Non-wastewaters with greater than } \\
\text { or equal to } 260 \mathrm{mg} / \mathrm{kg} \text { total } \\
\text { mercury [including residues from } \\
\text { mercury roasting or retorting } \\
\text { (RMERC) of U151 waste if it } \\
\text { contains greater than or equal to } \\
260 \mathrm{mg} / \mathrm{kg} \text { total mercury]. }\end{array}$ \\
\hline & B & $\begin{array}{l}\text { Low Mercury Non-wastewaters } \\
\text { from RMERC }\end{array}$ & & $\begin{array}{l}\text { Non-wastewaters with less than } \\
260 \mathrm{mg} / \mathrm{kg} \text { total mercury and that } \\
\text { are residues from RMERC of U151 } \\
\text { wastes. }\end{array}$ \\
\hline & $\mathbf{C}$ & Low Mercury Non-wastewaters & & $\begin{array}{l}\text { Non-wastewaters with less than } \\
260 \mathrm{mg} / \mathrm{kg} \text { total mercury that are } \\
\text { not residues from RMERC. }\end{array}$ \\
\hline & $\mathbf{D}$ & $\begin{array}{l}\text { Elemental Mercury } \\
\text { Contaminated with Radioactive } \\
\text { Materials }\end{array}$ & & \\
\hline & $\mathbf{E}$ & Mercury Wastewaters & & $\begin{array}{l}\text { All U151 (mercury) waste managed } \\
\text { as wastewaters. }\end{array}$ \\
\hline \multirow[t]{3}{*}{$\mathrm{U} 240$} & $\overline{\mathbf{A}}$ & $\begin{array}{l}\text { 2, 4-D (also known as } \\
\text { Dichlorophenoxyacetic Acid) }\end{array}$ & & $\begin{array}{l}\text { 2,4-D as a discarded commercial } \\
\text { chemical product, off-specification } \\
\text { species, container residues, or spill } \\
\text { residues. }\end{array}$ \\
\hline & $\mathbf{B}$ & $\begin{array}{l}\text { 2, 4-D (Dichlorophenoxyacetic } \\
\text { Acids) Salts \& Esters }\end{array}$ & & $\begin{array}{l}2,4-D \text { salts or esters as discarded } \\
\text { commercial chemical products, off- } \\
\text { specification species, container } \\
\text { residues, or spill residues. }\end{array}$ \\
\hline & $\mathbf{C}$ & Unspecified U240 Waste & & $\begin{array}{l}\text { U240 waste, but characterization } \\
\text { information is insufficient to } \\
\text { determine whether the A or B } \\
\text { subcode is appropriate. }\end{array}$ \\
\hline
\end{tabular}


Tritium Facilities Modernization \& Consolidation Project Process Waste Assessment
WSRC-TR-97-00368, Rev.0

November 14,1997

[This Page Intentionally Left Blank] 